\title{
ESCOLARIDADE E SUAS IMPLICAÇÕES NO MERCADO DE TRABALHO RURAL NO ESTADO DO PARANÁ, 1970 e 1980
}

\section{ANTONIO CARLOS DE CAMPOS}

Economista

Orientador: Prof. Dr. PEDRO CARVALHO DE MELLO

Dissertação apresentada à Escola Superior

de Agricultura "Luiz de Queiroz".

Universidade de São Paulo. para obtenção do título de Mestre em Ciências. Área de Concentração: Economia Aplicada.

\footnotetext{
PIRACICABA

Estado de São Paulo - Brasil

Fevereiro -1998
} 
Dados Internacionais de Catalogação na Publicação (CIP) DIVISÃO DE BIBLIOTECA E DOCUMENTAÇĀO - Campus "Luiz de Queiroz"/USP

Campos, Antonio Carlos de

Escolaridade e suas implicaçōes no mercado de trabalho rural no Estado do Paraná, 1970 - 1980 / Antonio Carlos de Campos. - - Piracicaba, 1998

$107 \mathrm{p}$.

Dissertação (mestrado) - Escola Superior de Agricultura Luiz de Queiroz, 1998. Bibliografia.

1. Educação agricola 2. Mercado de trabalho agricola 3. Paraná 4. Produtividade agricola 5. Salário rural I. Titulo

CDD 331.63 


\section{ESCOLARIDADE E SUAS IMPLICAÇŌES NO MERCADO DE TRABALHO RURAL NO ESTADO DO PARANÁ, 1970 e 1980}

\section{ANTONIO CARLOS DE CAMPOS}

Aprovada em: 06/04/98

Comissão julgadora:

rof. Dr. Pedro Carvalho de Mello

ESALQ/USP

Prof. Dr. Paulo Fernando Cidade de Araújo

ESALQ/USP

Prof. Dr. Angela Maria Cassavia Jorge Corrêa

UNIMEP

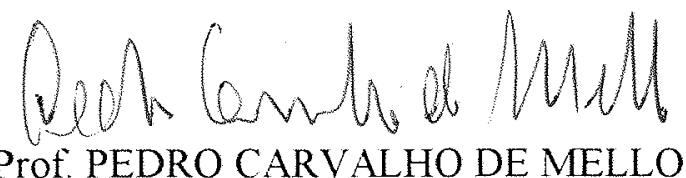

Orientador 


\section{Dedicatória}

A minha esposa Gislaine pelo apoio. carinho e amor constante:

As familias Campos e Manetta pela compreensão da minha ausència;

Àqueles que iniciaram o curso e, por motivos diversos, não conseguiram sua conclusão:

A Deus; pela vida.

Dedico 


\section{Agradecimentos}

Desejo exprimir o meu agradecimento ao Prof. Dr. Pedro Carvalho de Mello, a quem devo a orientação deste trabalho, realizada com ética e espirito cientifico.

Aos docentes do programa de mestrado em Economia Aplicada da ESALQ/USP e, em particular, ao Prof. Dr. Paulo Fernando Cidade de Araujjo, a Prof. Dr" Zilda Paes de Barros Mattos e ao Prof. Dr. Dálcio Caron pelas valiosas sugestões à preparação deste trabalho, a minha gratidão.

A prof. $\mathrm{Dr}^{\mathrm{i}}$ Angela Maria Cassavia Jorge Corrèa (UNIMEP) pelas preciosas sugestões, o meu agradecimento.

Ao Prof. Dr. Antonio Carlos Lugnani da Universidade Estadual de Maringá (UEM) pela disposição como integrante da banca examinadora

Ao professor e amigo Dr. Errol Alva Carvers Forde da Universidade Estadual de Maringá (UEM) pela participação na minha formação acadêmica, incentivo para realização deste curso e pelas valiosas sugestões.

Ao Prof. Virgilio de Almeida da Universidade Estadual de Maringá (UEM) pela leitura crítica e importantes sugestões.

Agradeço também a Universidade Estadual de Maringá - UEM, em particular, ao Departamento de Economia, pela oportunidade de realizar este programa de capacitação docente; à CAPES, pelo financiamento concedido.

Aos funcionários do departamento de Economia e Sociologia Rural e, em especial a Maiele, Luciane, Angélica, Cristiane; Helena e Valdeci pela competència, dedicação e amizade.

À família Bulhões pelo carinho; a amiga de todos os momentos Márcia Istake pela convivência; aos amigos Edivaldo e Nancy pelos bons momentos; ao amigo Alexandre Alves pelo apoio; ao amigo Edson Martins pela constante alegria; enfim, a todos os colegas da ESALQ/USP pelo companheirismo. 


\section{SUMÁRIO}

Página

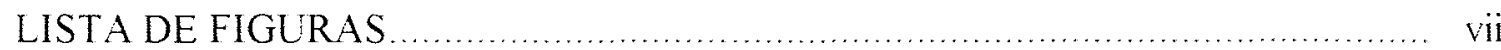

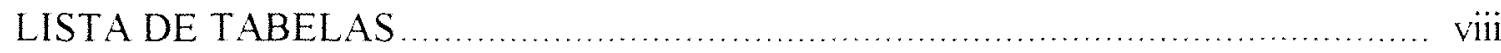

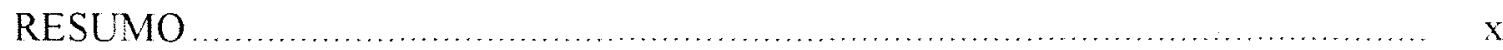

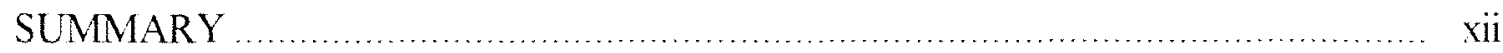

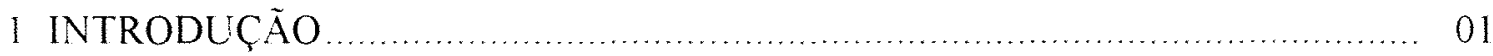

1.1 A importància da aggricultura para o desenvolvimento econòmico ................... 01

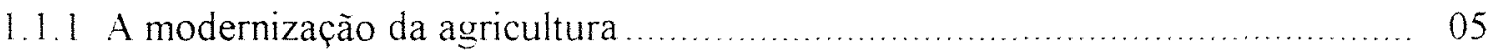

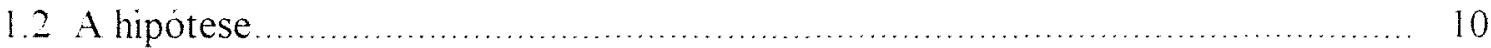

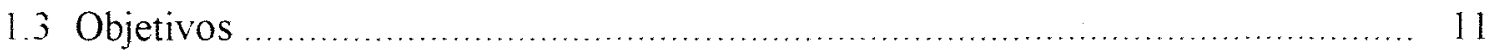

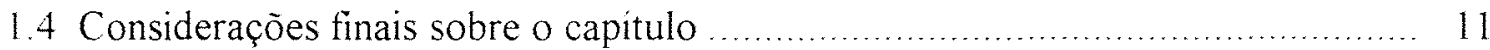

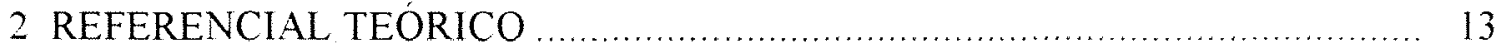

2.1 O capital humano em um contexto de crescimento econômico ..................... 13

2.2 Educação e o desenvolvimento agrícola .............................................. 18

2.3 Educação, modernização da agricultura e a migração rural-urbana .................. 21

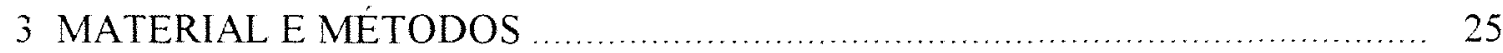

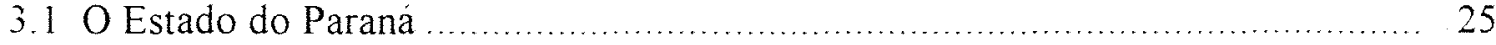

3.2 Considerações metodológicas ...................................................... 30

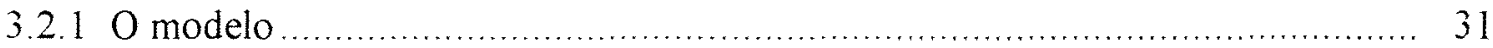

3.2 .2 As equações de demanda e oferta .............................................. 33

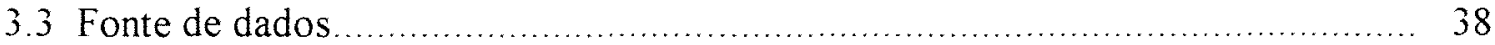

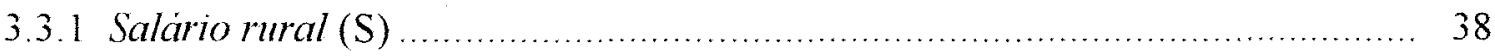

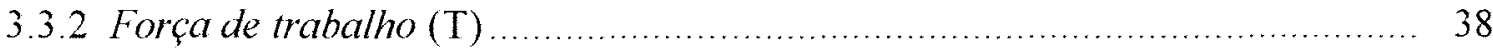

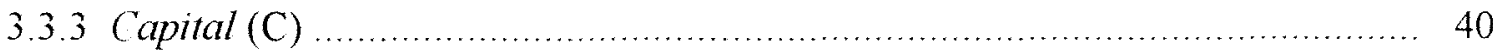

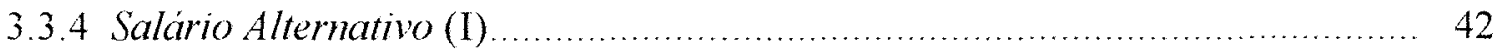

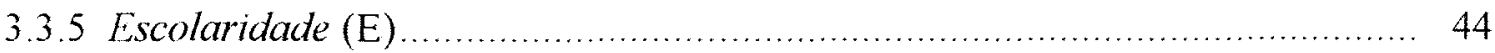

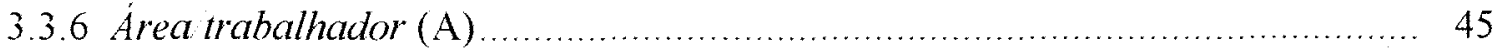


4 RESULTADOS E DISCUSSÕES ....................................................... 46

4.1 Descrição e análise das variáveis .................................................... 46

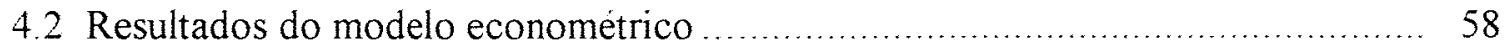

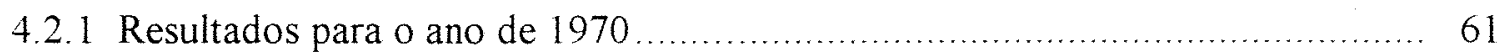

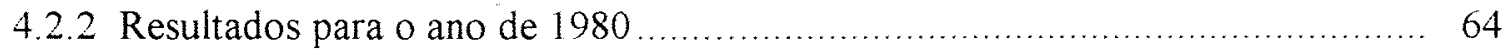

4.2.3 Resultados para o conjunto (poo/) 1970-1980 .................................. 66

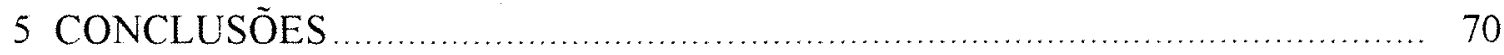

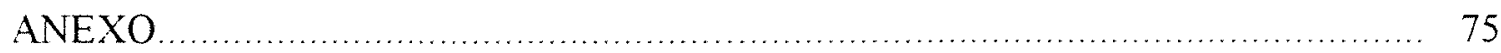

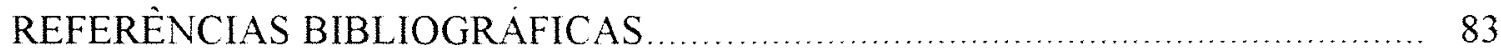

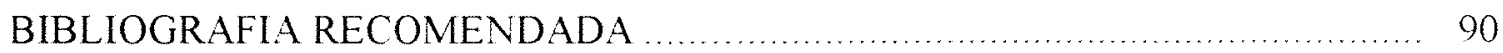

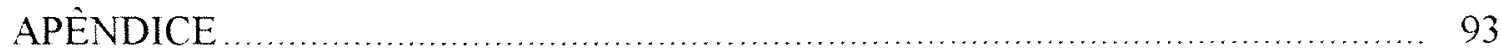




\section{LISTA DE FIGURAS}

Página

1 Oferta e demanda por trabalhadores no mercado de trabalho rural 


\section{LISTA DE TABELAS}

Página

1 População residente (milhões) por situação de domicilio, no Brasil, 1940-95 ..... 04

2 Rendimento médio real mensal (em salário mínimo) das pessoas de 10 anos ou mais de idade, economicamente ativas, com rendimentos por situação de domicilio, e classes, 1981-1990

3 Area média (em mil ha) ocupada com as principais culturas do Estado do Paraná, suas variaçōes de 1974-1985.

4 Valores reais em crédito destinado à atividade agrícola do Brasil e do Paraná, participação percentual do Paraná no crédito agrícola, taxa real de juros e subsidio concedido à atividade agrícola do Paraná

5 Produto Interno Bruto (PIB) do Brasil e do Paraná; proporção do PIB do Paraná em relação ao PIB do Brasil; PIB per capita do Brasil e do Paraná, $1980-1994$

6 Salário rural/ano e estatísticas selecionadas, por MRH, 1970 e1980. 47

7 Força de trabalho/ano e estatisticas selecionadas, por MRH, 1970 e 1980. 49

8 Capital/ano e estatisticas selecionadas, por MRH, 1970 e 1980. 51

9 Escolaridade e estatísticas selecionadas, por MRH, 1970 e 1980. 52

10 Salário alternativo ano e estatísticas selecionadas, por MRH, 1970 e $1980 \ldots \ldots .53$

11 Área trabalhador ano e estatísticas selecionadas, por MRH, 1970 e 1980. 55

12 Matriz de correlações simples entre as variáveis salário rural (S), força de trabalho (T), capital (C), salário alternativo (I) e escolaridade (E) e Área trabalhador (A) para o ano de 1970

13 Resultados estatísticos da estimativa da demanda por força de trabalho, $1970 \ldots 62$

14 Resultados estatísticos da estimativa de oferta por força de trabalho, 1980 63 
15 Matriz de correlações simples entre as variáveis salário rural (S), força de trabalho (T), capital (C), salário alternativo (I), escolaridade (E) e áreatrabalhador (A) para o ano de 1980

64

16 Resultados estatisticos da estimativa da demanda por força de trabalho, $1980 \ldots 65$

17 Resultados estatísticos da estimativa de oferta por força de trabalho, $1980 \ldots \ldots .66$

18 Matriz de correlações simples entre as variáveis salário rural (S), força de trabalho (T), capital (C), salário alternativo (I), escolaridade (E), àreatrabalhador (A) e dummy para ("Poof") 1970-1980.

19 Resultados estatisticos da estimativa da demanda por força de trabalho, ("Pool") 1970-1980.

20 Resultados estatísticos da estimativa da oferta por força de trabalho, ("Pool") $1970-1980$ 


\title{
ESCOLARIDADE E SUAS IMPLICAÇÕES NO MERCADO DE TRABALHO RURAL NO ESTADO DO PARANÁ, 1970 e 1980
}

\author{
Autor: ANTONIO CARLOS DE CAMPOS \\ Orientador: Prof. Dr. PEDRO CARVALHO DE MELLO
}

\section{RESUMO}

A hipótese deste estudo é que um trabalhador rural relativamente melhor qualificado tem rendimentos superiores em comparação aos que possuem nivel de qualificação menor. Com o objetivo de identificar se o nivel de educação formal determina o nivel de rendimento dos trabalhadores do setor agricola do Estado do Paraná, foram levantados dados sobre salário rural, número de pessoas ocupadas, quantidade de capital, relação Área/trabalhador, anos de escolaridade e, por fim, os salários dos trabalhadores da indústria da construção civil (salário alternativo), em cada Microrregião Homogênea.

A metodologia utilizada empregou análise descritiva evidenciando as interrelações entre as variáveis dependentes e independentes e, também, estimativas de curvas de oferta e de demanda por trabalho no meio rural nos anos de 1970, 1980 e no conjunto 1970-1980 ("pool"), obtendo as respectivas elasticidades com os coeficientes estimados

No que se refere à escolaridade verificou-se, na análise descritiva entre as variáveis e nos resultados do modelo econométrico adotado, uma associação positiva com o salário rural. Esta variável mostrou-se importante na determinação dos rendimentos dos trabalhadores rurais, principalmente para as equações de oferta, indicando que um aumento nos níveis de educação formal implica elevação dos salários

desses trabalhadores. Esse resultado permitiu concluir que os niveis de escolaridade foram significativos para o efeito mobilidade, ou seja, de aumentar as possibilidades de o 
trabalhador rural buscar outros trabalhos fora do setor agricola do estado. Entretanto, para as equações de demanda, verificou-se que todos foram não-significativos estatisticamente, indicando que o efeito capacitação não se verificou para os trabalhadores rurais do Paraná. Acredita-se que, pelo fato de os niveis de escolaridade terem apresentado-se baixos, os empresários agrícolas foram indiferentes na contratação de trabalhadores com maiores ou menores niveis de escolaridade, haja vista a pouca diferença entre os mesmos. Dessa forma, os resultados obtidos permitiram concluir que a educação formal representou importante papel na determinação dos niveis de rendimentos, via efeito mobilidade, nos anos de 1970 e 1980.

Outros resultados encontrados indicaram que os niveis salariais dos trabalhadores rurais tambem foram influenciados por mudanças em outras variáveis. Entre elas, ressalta-se que a variável força de trabalho apresentou, na análise descritiva, modesta relação com os salários rurais. Já na análise econométrica, a relação apresentouse de acordo com as expectativas iniciais, indicando, para a equação de oferta, que um aumento nos niveis salariais provocaria a elevação da quantidade ofertada de mão-deobra no setor rural. No entanto, na equação de demanda, nenhum dos paràmetros estimados foi significativo estatisticamente.

Tanto a variável capital quanto Área/trabalhador mostraram-se favoráveis à determinação dos salários dos trabalhadores rurais do Paraná nas equações de demanda. Tanto o aumento do capital quanto da relação Área/trabalhador influenciaram positivamente na elevação do valor do produto marginal do trabalho. No que se refere à variável salário industrial, observou-se sinal contrário em relação às expectativas iniciais para o ano de 1970. No ano de 1980 e no conjunto 1970-1980, apesar de os sinais esperados com base na teoria econômica, essa variável apresentou baixos coeficientes de elasticidade, indicando certa fragilidade no tocante à determinação da renda. 


\title{
SCHOOLING AND ITS IMPLICATIONS IN THE RURAL LABOR MARKET IN THE STATE OF PARANÁ, 1970 AND 1980
}

\author{
Author: ANTONIO CARLOS DE CAMPOS \\ Adviser: Prof. Dr. PEDRO CARVALHO DE MELlo
}

\section{SUMMARY}

The study is based on the hypothesis that relatively better qualified rural workers earn higher wages than those with a lesser qualification. In order to identify whether the level of formal education determines the yielding level of the agricultural sector in the state of Paraná, data on rural wages, number of people with occupation, amount of funds, area/worker relationship, school years, and finally the wages of civil construction workers (alternative wage) in each Homogenous Microregion were surveyed.

A descriptive analysis stressing the interrelationships between dependent and independent variables as well as the curve estimates of work supply and demand in the rural area in the 1970's, 1980's, and pooled 1970-1980's was used to determine the respective elasticities with the estimated coefficients.

With regards to schooling a positive relationship with rural wages was verified between these variables in the descriptive analysis and the results if the econometric model adopted. This variable was important to determine rural workers wages, specially for the supply equations, thus indicating that higher formal education levels implies higher wages. This result showed that the school background was significant to the mobility effect in that rural workers had higher possibilities of searching for work beyond the agricultural sector in that state. For the demand equations, however, all were statistically negligible thus indicating that the background effect was not observed for rural workers in Parana. Due to the fact that school background was low, agricultural entrepreneurs are believed to have been indifferent as to higher or lesser school background workers at 
hiring in view of the slight difference between them. This way, the results showed that the formal education played an important role in the determination of the yield levels via mobility effect from 1970 through 1980.

Further results indicated that the wage levels of rural workers were influenced by the changes in other variables. The manpower variable showed a moderate relationship with rural wages at the descriptive analysis while at the econometric one the relationship met the initial expectation thus indicating that for the supply equation a raise in wage levels would lead to a higher number of supplied hand labor in the rural sector. However, none of the estimated parameters was statistically significant for the demand equation.

Both fund and area/worker variables were favorable to the determination of rural workers wages in Parana in the demand equations. Both the increased funds and area/worker relationship positively influenced the increase of the marginal product value of work. In regard to the industrial wage variable an opposite sign was observed in relationship with the initial expectation for the year of 1970. In spite of the expected signs based on the economic theory, this variable presented elasticity coefficients were low in 1980 and pooled 1970-80, thus indicating a certain fragility concerning income determination. 


\section{INTRODUCÃO}

Vários trabalhos já foram realizados tratando da importância da agricultura e sua modernização para o processo de desenvolvimento econòmico ${ }^{1}$. Também foram feitos diversos estudos sobre o progresso da agricultura e suas implicações no mercado de trabalho, bem como sobre a distribuição dos rendimentos ${ }^{2}$. Da mesma forma, estudos acerca da educação mostraram sua importância para o desenvolvimento econōmico ${ }^{3}$, conjuntamente com os itens anteriores.

Diante disso, este capitulo pretende tratar de questões como o papel da agricultura para o desenvolvimento econômico, relacionando a importância da modernização e suas implicações, a fim de evidenciar o assunto analisado neste trabalho. Para tanto, o capitulo foi subdividido em cinco subitens, destacando-se inicialmente a importância da agricultura para o desenvolvimento econômico. Em seguida, o segundo subitem aborda o processo de modernização em um contexto de desenvolvimento econômico. O terceiro e o quarto subitens destacam a hipótese e os objetivos do trabalho, respectivamente. Por fim, o quinto aborda as principais considerações desenvolvidas neste capítulo.

\subsection{A importância da agricultura para o desenvolvimento econômico}

Nos paises em desenvolvimento, com freqüencia o setor agrícola possui grande participação no PIB e, muitas vezes, é a principal fonte geradora de empregos.

\footnotetext{
Johnston \& Mellor (1961), Hayami \& Ruttan (1970), Nicholls (1975), entre outros.

"Hotł̇nann \& Kageyama (1985), Alves (1995), Barros \& Mendonça (1995) etc..

${ }^{3}$ Schultz (1961 e 1973), Denison (1962), Mincer (1974) e Becker (1993).
} 
Segundo o relatorio do Banco Mundial (1996), em paises de baixa renda, mais de $60 \%$ da força de trabalho estão empenhados em atividades agricolas e pelo menos $40 \%$ do PNB vèm desse setor. Destaca-se que mesmo em paises de renda média alta, esta participação apresenta-se significativa $^{+}$. A importância da agricultura para o processo de desenvolvimento econômico foi tratada inicialmente por Johnston \& Mellor (1961), que destacaram as funções ${ }^{5}$ que a agricultura deveria desempenhar. Dessa maneira, as funções da agricultura no processo de desenvolvimento econòmico serão discutidas a seguir.

A primeira função diz respeito ao fornecimento de alimentos para a população total. Com as altas taxas de crescimento populacional o aumento da produção de alimentos torna-se um fator de extrema importància. Nos paises em desenvolvimento, a elasticidade-renda da demanda por produtos agrícolas é mais elevada em comparação com os paises desenvolvidos. Sendo assim, pode-se destacar que uma diminuição nos preços dos alimentos implica um ganho real nos salários, principalmente para aqueles que destinam uma fração elevada ao consumo de alimentos ${ }^{6}$. Considerando que grande parte dos salários é utilizada na compra de alimentos, se os mesmos estiverem baratos, os salários nominais podem ser mantidos também em um nivel baixo, tanto no setor agricola como fora dele. Caso contrário, se os preços dos alimentos se elevarem, também aumentam os salários, criando uma dificuldade para o crescimento do setor nãoagricola. Portanto, a expansão da produção de alimentos torna-se um fator fundamental para o processo de desenvolvimento econômico.

A segunda função refere-se ao fornecimento de capital para a economia, especialmente para o setor não-agrícola. A agricultura, como fonte de capital para a economia, promove as transferèncias de capital do setor agricola para o não-agricola. Entretanto, isso pode diferenciar-se de acordo com os estágios de

\footnotetext{
+ Ressalta-se que o Brasil é considerado, pelo Banco Mundial, um país de renda média alta. Segundo o Relatorio sobre o Desenvolvimento Humano no Brasil (1996), 23\% da força de trabalho estiveram empenhadas em atividades agricolas em $1990 \mathrm{e}$, em $1995,11,4 \%$ do PIB foi originado por este setor.

"A apresentação e a discussão das funções da agricultura estão baseadas em Johnston \& Mellor (1961).

- Estas implicações são denominadas de bens-salários.
} 
desenvolvimento de cada economia. A forma mais usual de transferència encontra-se no sistema financeiro, captando poupanças do setor agricola e as transferindo para o industrial.

Já a terceira função compreende o fornecimento de mão-de-obra para 0 setor não-agrícola. A população agricola possui importante papel na produção de alimentos para toda a sociedade. A medida que aumenta a necessidade de mão-de-obra do setor não-agricola, cabe ao setor agrícola o seu fornecimento e a quantidade produzida de alimentos cabe a um numero menor de trabalhadores. Logo, o aumento da produtividade é uma condição requerida para o crescente fornecimento de alimentos. No entanto, o fluxo de mão-de-obra serve, também, como forma de arrefecer as elevações dos salários nominais no setor não-agricola, facilitando seu processo de industrialização.

A quarta função é o fornecimento de ganhos cambiais. Nos paises em desenvolvimento, onde a agricultura possui grande importància na economia, o setor agrícola é o grande responsável pela geração de divisas através do grande volume das exportações de seus produtos. Essas divisas podem ser usadas na compra de insumos externos, necessários ao desenvolvimento do setor não-agricola, auxiliando no processo de crescimento econòmico.

Por fim, a quinta função encontra-se no fato de a agricultura proporcionar um amplo mercado para os produtos não-agrícolas. Alguns segmentos do setor industrial necessitam de escala para operar. Assim, a expansão do mercado torna-se condição necessária. Como o setor agricola dos paises em desenvolvimento possui grande parte das pessoas empregadas e percebe uma parte considerável da renda gerada, esse mercado é extremamente importante para os produtos não-agricolas.

As funções ou os papéis descritos anteriormente são considerados clássicos na literatura sobre o desenvolvimento econòmico e serviram de base para muitos trabalhos posteriores. Araújo (1996), por exemplo, destaca a importância do setor agrícola no processo de crescimento econômico, como fonte geradora de recursos para a 
expansão do setor urbano-industrial, principalmente no periodo inicial da industrialização brasileira.

Outros estudos foram feitos acerca do papel da agricultura para o desenvolvimento econòmico brasileiro, demonstrando que as funções clássicas ${ }^{7}$ foram cumpridas de maneira satisfatória, existindo, no entanto, controvérsia ${ }^{8}$ no que diz respeito ao seu impacto no processo da industrialização brasileira a partir dos anos 50 .

Segundo Romeiro (1990), nos países desenvolvidos, onde o acesso à terra foi mais livre, a agricultura teve papel decisivo para o crescimento econòmico e se deu com razoável distribuição de renda, garantindo um èxodo rural compativel com as oportunidades de empregos gerados pelo emergente setor urbano-industrial.

No Brasil a agricultura também desempenhou seu papel para o desenvolvimento econômico, principalmente no tocante ao fornecimento de mão-de-obra para o setor industrial emergente. Pode ser observada (Tabela 1) a perda relativa da população residente entre campo e cidade de 1940 a 1995.

\begin{tabular}{cccccc}
\multicolumn{5}{c}{ Tabela } & \multicolumn{5}{c}{ População residente (milhões) } & por situação de domicilio, no Brasil & $1940-95$ \\
\hline Ano & Total & Urbana & Rural & \% Urbana & $\%$ Rural \\
\hline 1940 & +1.2 & 12.9 & 28.4 & 31.2 & 68.8 \\
1950 & 51.9 & 18.8 & 33.1 & 36.2 & 63.8 \\
1960 & 70.1 & 31.3 & 38.7 & 44.7 & 55.3 \\
1970 & 93.1 & 52.1 & 41.1 & 55.9 & $4+.1$ \\
1980 & 119.0 & 80.3 & 38.7 & 67.5 & 32.5 \\
1985 & 131.4 & 95.4 & 36.0 & 72.6 & 27.4 \\
1990 & 147.3 & 109.1 & 38.1 & 74.1 & 25.9 \\
1995 & 152.4 & 120.4 & 32.0 & 79.0 & 21.0 \\
\hline
\end{tabular}

Fonte: FIBGE - Estatísticas Históricas do Brasil (1993); PNAD (1985, 1990, 1995)

\footnotetext{
Como funçōes clássicas entende-se as destacadas por Johnston \& Mellor (1961).

${ }^{8}$ Diversos autores discutiram e apontaram conclusões divergentes quanto ao cumprimento ou não do papel da agricultura para o desenvolvimento do setor urbano-industrial brasileiro. Entre eles destacam-se Furtado (1964) e Castro (1972).
} 
A proporção de residentes na zona rural diminuiu acentuadamente, de $68,8 \%$, em 1940, para 32,5\% em 1980. A partir do ano de 1980, o crescimento percentual do setor urbano continuou, mas em proporções menores. Ao longo do periodo de 1940 a 1995 , o setor urbano passou de $31,2 \%$ para $79,0 \%$, enquanto o setor rural caiu de $68,8 \%$ para $21,0 \%$, em termos de população residente por situação de domicilio.

Faz-se necessário ressaltar que a população rural, em números absolutos, cresceu até 1970 , chegando a 41,1 milhões de habitantes. Já a partir dos anos 70 , os dados mostram diminuição da quantidade da população rural, chegando, em 1995, a 32 milhões de habitantes. Isto deve ser explicado, em parte, pelo processo de modernização da agricultura, pela legislação trabalhista, por mudanças na composição da produção, entre outros fatores, os quais provocaram mudanças na estrutura produtiva, bem como diminuição de trabalhadores empregados no setor agrícola.

\subsubsection{A modernização da agricultura}

A definição de modernização da agricultura varia entre autores. Nos trabalhos sobre o assunto, eles destacam diversas variáveis", que visam a medir, conjuntamente, o grau de modernização de determinada região. No presente trabalho, no entanto, tratar-se-á o termo modernização da agricultura como um conjunto de variáveis que visam a aumentar a produtividade dos fatores de produção. De forma sintética, podese ressaltar que a modernização implica não somente aumento de produtividade como também indução da migração de trabalhadores do setor agrícola para o não-agricola.

$\mathrm{Na}$ literatura, também há disponiveis trabalhos destacando a dificuldade do processo de modernização e sua consolidação. Os estudos de Schuh (1975) mostram que o processo de modernização da agricultura brasileira caminhou, a partir da década de 60 ,

\footnotetext{
${ }^{9}$ Hoffman (1992, p. 273-274), por exemplo, destacou 31 variaveis.
} 
a passos vagarosos e que não foi tão simples quanto aparentou, pois existiram algumas dificuldades $^{10}$ em sua difusão.

Paiva (1975) atribui o êxito da modernização da agricultura, em parte, ao setor não-agricola. Segundo o autor, a modernização da agricultura possui um mecanismo de autocontrole endógeno em seu processo. Isso acontece porque a difusão de técnicas modernas desencadeia mudanças nas relações de preços dos produtos e dos fatores tradicionais. Essas mudanças freiam a própria difusão, até que surjam novas mudanças de preços ou de técnicas. O desencadeamento dá-se da seguinte forma: o aumento da difusão da tecnologia moderna leva ao aumento da produção; esta, por sua vez, implica diminuição dos preços dos produtos. Com maior taxa de difusão, os preços dos fatores tradicionais também diminuem. Quando há diminuição dos preços dos produtos, altera-se a relação $\left(\frac{\mathbf{P}_{\mathrm{q}}}{\mathbf{P}_{\mathrm{X}}^{\mathrm{m}}}\right)$, onde $\left(\mathbf{P}_{\mathrm{q}}\right)$ é o preço do produto e $\left(\mathbf{P}_{\mathrm{X}}^{\mathrm{m}}\right)$ o preço dos fatores modernos, e a vantagem tecnológica torna-se menor. Ao haver queda dos preços dos fatores tradicionais $\left(\mathbf{P}_{\mathbf{X}}^{\mathbf{t}}\right)$, muda-se a relação entre o preço dos fatores modernos e os preços dos fatores tradicionais $\left(\frac{\mathbf{P}_{\mathrm{X}}^{\mathrm{m}}}{\mathbf{P}_{\mathrm{X}}^{\mathrm{t}}}\right)$ e, com isso, a vantagem da tecnologia moderna torna-se ainda menor, podendo tornar-se até mesmo desvantajosa. Portanto, a queda dos preços dos produtos e dos preços dos fatores tradicionais constituem-se em um freio ao processo de modernização da agricultura. Com isso, constata-se que tal processo está preso a um mecanismo de autocontrole, no qual os elementos de desestímulo são criados dentro do próprio crescimento da modernização ${ }^{\text {II }}$.

No Brasil, segundo Landim \& Monteiro (1991), o processo de modernização da agricultura deu-se mais por fatores exógenos. Os autores destacam que, no período do Plano de Metas, juntamente com os estímulos à indústria automobilistica, estavam embutidos estímulos a um subsetor de bens de produção para a agricultura:

\footnotetext{
${ }^{10}$ Um dos obstáculos citados pelo autor retere-se as facilidades de ocupação de novas terras, principalmente no Paranà, sul do Mato Grosso e em Goiás.

"Para melhor compreensão do processo de modernização e do mecanismo de autocontrole, ver Paiva (1975).
} 
tratores e equipamentos agricolas. Paralelamente a isso, havia também estimulos ao setor de insumos químicos, para o complemento da modernização agricola. Outro fator favorável ao processo de modernização da agricultura foi a criação, por parte do governo, do sistema nacional de crédito rural. A disponibilidade dos créditos viabilizou a consolidação do modelo de desenvolvimento agrícola, baseado principalmente na utilização de insumos industriais com vistas aos produtos de exportação

Estudos empiricos mostram que o processo de modernização da agricultura provocou profundas modificaçōes não só no sistema produtivo como tambem na estrutura fundiária, no mercado de trabalho e na distribuição da renda. Andrade (1989) estudou as relações entre processo de modernização da agricultura. estrutura fundiária e distribuição de renda na agricultura mato-grossense e concluiu que há associação positiva entre modernização e rendimento medio e associação negativa entre modernização e índice de pobreza. Hoffmann \& Kageyama (1985) chegaram à mesma conclusão para a agricultura brasileira, mostrando que o grau de modernização está associado ao rendimento médio e à desigualdade da distribuição de renda.

Del Grossi (1989), utilizando a mesma metodologia de Andrade (1989) e Hoffmann \& Kageyama (1985), observou uma correlação significativa e positiva entre renda média e desigualdade da distribuição de renda. Destacou ainda que os efeitos benéficos da modernização, propiciando o aumento de renda média, foram neutralizados pelo aumento da desigualdade da distribuição de renda. Outro trabalho a esse respeito foi o de Kiyuna (1990), que teve como objetivo estudar os impactos da modernização da agricultura paulista sobre a distribuição de renda do setor agrícola. O autor concluiu que a modernização possui um efeito positivo sobre as rendas média e mediana, enquanto que os fatores de modernização e desigualdade relacionaram-se inversamente

Os estudos destacados anteriormente mostram que existe uma relação positiva entre modernização e rendimentos. Segundo Romeiro (1990), sob uma visão 
neoclássica, as oportunidades de emprego no setor urbano-industrial favorecem a migração rural-urbana e isso pode incentivar a modernização tecnológica e o aumento dos salários dos trabalhadores agricolas, por um lado, pela sua escassez relativa e, por outro, pelo aumento de produtividade. Tal fato aconteceu em paises desenvolvidos Entretanto, no Brasil, mesmo com o setor agricola fornecendo mão-de-obra ${ }^{12}$ para o setor urbano-industrial, os salários dos seus trabalhadores diminuíram comparativamente aos do setor não-agrícola (Tabela 2). Aparentemente, a partir dos anos 80, o setor agricola liberou mais mão-de-obra do que as quantidades requeridas pelo setor nãoagricola

Tabela 2. Rendimento médio real mensal (em salário minimo) das pessoas de 10 ou mais anos de idade, economicamente ativas, por situação de domicilio e classes de idade, $1981-1990$

\begin{tabular}{|c|c|c|c|c|c|c|c|c|}
\hline \multirow[b]{2}{*}{ Classe de idade } & \multicolumn{3}{|c|}{ Urbano } & \multicolumn{3}{|c|}{ Rural } & \multicolumn{2}{|c|}{$\begin{array}{l}\text { \% do rendimento rural } \\
\text { em relação ao urbano }\end{array}$} \\
\hline & 1981 & 1990 & $\Delta \%$ & 1981 & 1990 & $\Delta \%$ & 1981 & 1990 \\
\hline até 10 & 0.5 & 0.5 & 0.0 & 0.3 & 0.2 & -33.3 & 60.0 & +0.0 \\
\hline+ de 10 a 20 & 1.2 & 1.0 & -16.7 & 0.7 & 0.5 & -28.6 & 58.3 & 50.0 \\
\hline+ de 20 a 30 & 1.7 & 1.2 & -29.4 & 0.8 & 0.7 & -12.5 & +7.0 & 58.3 \\
\hline+ de 30 a 40 & 2.1 & 1.8 & $-1+.3$ & 1.1 & 0.9 & -18.2 & 52.4 & 50.0 \\
\hline+ de +0 a 50 & 2.6 & 2.3 & -11.5 & 1.4 & 1.1 & -21.4 & 53.8 & +7.8 \\
\hline+ de 50 a 60 & 3.3 & 3.1 & $-1) .1$ & 1.7 & 1.4 & -17.6 & 51.5 & +5.2 \\
\hline+ de 60 a 70 & +.3 & +.2 & -0.1 & 2.1 & 1.8 & $-1+.3$ & 48.8 & +2.8 \\
\hline+ de 70 a 80 & 5.8 & 5.7 & 0.0 & 2.6 & 2.4 & -0.1 & +4.8 & +2.1 \\
\hline
\end{tabular}

Fonte: FIBGE - Anuário Estatistico do Brasil - 1994

Analisando a evolução do rendimento médio (Tabela 2), verifica-se que a situação piorou em ambos os setores no ano de 1990 comparativamente a 1981 Entretanto, observa-se que o rendimento médio do setor rural mostrou-se sempre inferior

\footnotetext{
${ }^{12}$ Ressalta-se. na Tabela 1, que o setor rural diminuiu sua participação relativa na população residente, porém manteve certa regularidade da população em números absolutos até 1990. Dessa fonna, a oferta de trabalhadores pode não ter diminuido e, assim. não ter afetado significativamente os rendimentos dos trabalhadores.
} 
ao do urbano, representando basicamente a metade do rendimento do setor urbano nos dois anos analisados.

$\mathrm{O}$ fato de os rendimentos do setor não-agricola serem relativamente maiores que os do setor agricola pode, em parte, explicar o processo de migração ruralurbana pelo processo de atração, isto é, para haver migração é necessário que o salário do setor urbano seja relativamente mais elevado que os salários do setor agrícola. Todavia, a migração também pode ser corroborada pelo processo de expulsão, ou seja, a modernização possibilitou o emprego de culturas que demandavam mais máquinas e equipamentos em detrimento da mão-de-obra. Portanto, diminuiram significativamente as frentes de trabalho no campo, impelindo parte dos trabalhadores para o setor urbano Entretanto, na atual década, há uma tendência acentuada de diminuição desse processo, com o retorno de familias da zona urbana para a zona rural ${ }^{13}$.

Apesar da dificuldade de solidificação da modernização da agricultura, verifica-se que a mesma desempenhou papel fundamental no processo de crescimento econômico, principalmente a partir dos anos 70 , promovendo diversas mudanças na estrutura produtiva e no mercado de trabalho brasileiro. No que diz respeito à estrutura produtiva, constatou-se a substituição das culturas tradicionais ${ }^{14}$ pelas modernas, conforme Pereira \& Lugnani (1989), sendo as segundas mais intensivas em capital. Já no mercado de trabalho, a demanda por mão-de-obra mais qualificada aumentou e, com isso, aumentou também a importância da educação para fazer frente a essa necessidade.

Assim, o processo de modernização provocou, de um lado, o aumento de mão-de-obra excedente no campo, canalizado para o setor não-agricola $\mathrm{e}$, de outro, o aumento da demanda por trabalhadores mais qualificados. Dessa forma, para difusão e

\footnotetext{
${ }^{13}$ Ver a esse respeito Graziano da Silva (1996).

${ }^{14}$ Autores que tratam da modernizaçăo da agricultura denominam de culturas tradicionais aquelas que necessitam. em seu processo produtivo, de maior quantidade de mão-de-obra em relação ao capital. Jà as modernas são aquelas que utilizam mais intensamente máquinas e equipamentos agricolas (capital). Como exemplo das tradicionais destacam-se: caté, algodão, mandioca, arroz, amendoim etc.; como exemplo das modernas tem-se soja, trigo, entre outras. O milho, até os anos 70, era cultivado com grande utilização de mão-de-obra (tradicional). Nos anos 80, o mesmo passou a ser cultivado mais intensivamente com máquinas e instrumentos agricolas (moderna).
} 
consolidação da modernização da agricultura, deduz-se que foi requerida maior qualificação dos trabalhadores rurais, tornando o aumento do nivel de escolaridade uma condição necessária para atender às novas frentes de trabalho advindas de tal processo. Nesse contexto, espera-se que um trabalhador, em função do seu melhor nivel de qualificação, venha a ter um aumento em seus rendimentos. O fator de fundamental importância na determinação dos rendimentos diz respeito aos niveis educacionais, tema este que será amplamente discutido na revisão de literatura do presente estudo

\section{2 - A hipótese}

Como foi descrito na seção anterior, o processo de modernização da agricultura brasileira foi importante no periodo emergente da industrialização do país. De um lado, a modernização veio acoplada ao processo de desenvolvimento da indústria, transformando a agricultura, não só pelo fato de adquirir parte de seus produtos, mas por ter aumentado, de maneira significativa, o montante das vendas de insumos quimicos, máquinas e equipamentos, na maioria importados, estabelecendo um elo denominado mais tarde de Complexo Agro-industrial (CAI). De outro, possibilitou o aumento na produção de alimentos, matérias-primas e produtos de exportação, bem como forneceu excedentes de mão-de-obra ${ }^{15}$, necessários ao setor industrial emergente, colaborando para o cumprimento do papel da agricultura no processo de desenvolvimento econômico.

Nesse contexto, destaca-se que a modernização da agricultura aumentou a demanda por trabalhadores rurais com maior qualificação. Portanto, a hipótese deste estudo pode ser assim formulada: o trabalhador com maior nível de escolaridade aufere maior renda em função de sua maior produtividade. Tomar-se-á como estudo de caso o

\footnotetext{
15 O aumento da produção e o excedente de mão-de-obra advêm dos efeitos capacitação e mobilidade, respectivamente.
} 
investimento em educação formal e suas implicações no mercado de trabalho rural no Estado do Paraná, em 1970 e 1980.

\subsection{Objetivos}

O investimento educacional vem ganhando importància na literatura do desenvolvimento econòmico nos últimos anos e, nos dias atuais, constitui-se em um fator fundamental para o acesso ao mercado de trabalho. bem como para a determinação dos rendimentos dos trabalhadores. Dessa forma, o objetivo principal deste estudo é analisar o efeito do nível de escolaridade sobre o nivel de renda dos trabalhadores do setor agrícola no Estado do Paraná, em 1970 e 1980. Além desse objetivo maior, delineiam-se outros mais específicos a seguir:

i) analisar a contribuição do salário alternativo ${ }^{16}$ para o processo de migração ruralurbana:

ii) dimensionar o grau de contribuição do capital no processo de elevação dos niveis salariais;

iii) verificar os efeitos das inovações mecànicas, via razão área/trabalhador, nos salários dos trabalhadores rurais.

\subsection{Considerações finais sobre o capítulo}

O presente capítulo objetivou mostrar as interrelações da modernização e dos diferenciais de renda entre os trabalhadores dos setores agrícola e não-agricola com o

\footnotetext{
${ }^{10}$ Como salário altenativo será usado o salário per capita dos trabalhadores do setor da indústria da construção civil.
} 
desenvolvimento da agricultura. Entretanto, fez-se necessário também discutir o objeto principal deste estudo - a educação -, que também faz parte dessas interrelações, pois alguns autores atribuem a não-absorção dessa mão-de-obra aos baixos niveis educacionais dos migrantes do campo para a cidade. Dessa forma, destaca-se que a educação possui papel fundamental no processo de manutenção e consolidação do processo de modernização da agricultura, com a função de absorver e aprimorar as novas técnicas de produção emergentes. O capitulo seguinte pretende apresentar os estudos precursores da teoria do capital humano e suas evoluções, destacando os principais trabalhos e seus resultados sobre a importância da educação no processo de aumento de produtividade e renda dos trabalhadores. 


\section{REFERENCIAL TEÓRICO}

O capital humano vem ganhando espaço nas teorias sobre o crescimento econòmico no que se refere à sua contribuição para a explicação das taxas de crescimento da renda nacional. A fim de evidenciar esses trabalhos, este capitulo está subdividido em três seções: a primeira trata da importància do capital humano no crescimento econòmico. A segunda discute as implicações da educação no desenvolvimento da agricultura e, finalmente, a terceira analisa os efeitos da educação no processo de modernização e migração rural-urbana. Seu objetivo é enfocar o presente trabalho sob a ótica da teoria do capital humano.

\subsection{O capital humano em um contexto de crescimento econômico}

Com a globalização e o aumento de competitividade entre os paises, criouse maior demanda por produtos de melhor qualidade e menor preço. Para esse fim, o aumento dos niveis de qualificação e educação parece ser fator crucial para o processo de crescimento econòmico. No que se refere à educação, Theodore Schultz foi um dos precursores no estudo dos investimentos em capital humano e dos retornos dele advindos. Conforme Schultz (1961), o capital passa a ter um conceito mais amplo, incluindo capital humano e estoque de conhecimentos. Isto é, a educação não pode mais 
ser tratada como um custo, mas sim como investimento capaz de aumentar significativamente a produtividade dos fatores de produção.

Em trabalho de 1973, Schultz destaca que muito daquilo que chamamos de consumo, na verdade, são investimentos em capital humano. Os exemplos claros são os gastos com educação, saúde, migração interna para obtenção de vantagens com melhores empregos, entre outros. Sustenta ainda, que o impressionante crescimento dos rendimentos do trabalho pode ser explicado por essas formas de investimento. As diferenças nos rendimentos dão-se não só devido a fatores como sexo e idade. mas também pelas diferenças nos niveis de saude e educação, como afirma o autor.

\footnotetext{
"Muitos trabalhadores rurais migratórios ganham na verdade muito pouco, em comparação com outros trabalhadores. Muitos deles não tèm, virtualmente, nenhuma espécie de escolaridade, tèm saúde precária, não apresentam quaisquer capacidades especificas qualificadas, e têm pouca habilidade para executar trabalho util Acentuar que as diferenças no quantitativo do investimento humano podem explicar essas diferenças de rendimentos parece coisa elementar' (Schultz, 1973, p. 36).
}

Nesse mesmo estudo, o autor refere-se aos paises em desenvolvimento e sua dependência de capitais externos. Segundo ele, os escassos capitais são aplicados, em sua grande maioria, em máquinas e equipamentos, e até mesmo em mercadorias, mas não são, em proporção significativa, aplicados no homem. Dessa forma, o autor constata que a capacitação humana não é colocada em situação de igualdade com o capital físico, tornando-se, assim, um obstáculo ao crescimento econômico. Para ele, são necessários investimentos em capital humano para fazer frente aos investimentos em capital físico.

Denison (1962) investigou alguns fatores que contribuiram para o crescimento econômico norte-americano no século XX. Entre eles estava a educação que, no periodo de 1909 a 1929, contribuiu com 23\% para o aumento do produto; de 
1929 a 1957, com 42\%. Também Myint (1967), buscando auxilio na história, observa que o crescimento econòmico dos países desenvolvidos não é somente explicado pelo aumento quantitativo e mensurável de capital fixo. Há, ainda, um residuo que deve ser explicado em termos de produtividade dos recursos, devido a inovações e aperfeiçoamento nos metodos de produção e organização. Tal residuo estaria, então, relacionado a um maior nivel educacional.

A partir das idéias cruciais da importància do capital humano no aumento da produção, surgiram vários estudos destacando a necessidade da educaçào para o crescimento econòmico. O trabalho de Romer (1990) aponta que, até a década de 50 , os economistas atribuiram total importància às mudanças tecnológicas como causadoras do aumento do volume de produção. Segundo o autor, as mudanças tecnológicas possuem grande importància, mas não menos importante é o capital humano. Este tem também o papel de gerar novos produtos e idéias, auxiliando na evolução do progresso técnico.

No Brasil, a questão do aumento de renda em função de melhores níveis educacionais vem sendo estudada por diversos autores. Inicialmente, a maneira de medir a contribuição da educação para o aumento da renda foi utilizando a taxa interna de retorno. Com esse procedimento, Langoni (1974) mostrou em seu trabalho os valores da contribuição da educação no processo de crescimento da renda. Para o Brasil, o autor estimou que a taxa de retorno social dos investimentos em educação, em 1969, foi $28 \%$. Utilizando a mesma metodologia, Gibbon (1975) encontrou taxas internas de retorno para o Brasil, em educação primária, em 1970 , de $26,5 \%$ no setor primário, $45,9 \%$ no secundário e 41,4\% no terciário. Em um espaço geográfico menor, Alto Paraiba, no Estado de Minas Gerais, Ribeiro (1979) encontrou em seus estudos, para o período 1974-76, uma taxa interna de retorno de $24,8 \%$ ao ano para os investimentos em educação.

Outras metodologias foram utilizadas para mensurar o grau de contribuição da educação no nivel de renda. Segundo Barros \& Mendonça (1995), 
estudar os efeitos da educação sobre a renda é bastante complexo. Trabalhando intensamente com esse assunto, os autores explicam que a produtividade de um trabalhador deve ser mais elevada quanto maior sua qualificação. Isso explica os baixos niveis salariais dos muitos trabalhadores desqualificados e, em contrapartida, a alta produtividade dos trabalhadores mais qualificados, fazendo parte de um mercado de trabalho mais modernizado e com maior produtividade

Os autores ainda destacam que, nos paises desenvolvidos, onde os desniveis educacionais são menores, há certo congestionamento de trabalhadores qualificados exercendo pressão para baixo nos salários e certa escassez de trabalhadores menos qualificados pressionando os salários para cima. Isso contribui para a explicação de uma distribuição mais igualitária de renda. Em outras palavras, se o nivel educacional aumenta, diminuem a sensibilidade ${ }^{17}$ dos salários e as desigualdades de renda. Isto é, quando o sistema educacional se expande, a desigualdade salarial tende, inicialmente, a elevar-se, para diminuir posteriormente. Isso acontece, pois, quando o nivel educacional relativo aumenta, tanto a sensibilidade da educação como os salários também aumentam; mas, quanto mais cresce o nível educacional absoluto, mais a sensibilidade e os salários diminuem. No Brasil, aconteceu o contrário. O aumento do nivel educacional elevou a sensibilidade dos salários e as desigualdades de renda nos anos 60 . Entretanto, Langoni (1974) ressalta que a elevação dos niveis educacionais perdeu a corrida para o aumento da tecnologia e que isso elevou a sensibilidade e a desigualdade de renda. Os trabalhos nos levam a acreditar que só haverá diminuição da desigualdade de renda quando primeiro houver diminuição da desigualdade do nivel educacional. Espera-se então que, à medida que o nivel de escolaridade se eleve, os diferenciais de salários e produtividade entre os trabalhadores com alto e baixo nivel educacional se reduzam.

Utilizando uma metodologia mais sofisticada, que permite uma análise muito desagregada dos dados, Kassouf (1996) estudou os efeitos da educação no Brasil nos setores rural e urbano, encontrando vários resultados importantes. Entre os

\footnotetext{
${ }^{17}$ O termo sensibilidade assemelha-se ao conceito de elasticidade.
} 
principais, destaca-se que, para os homens, a participação no mercado de trabalho aumenta quando o numero de filhos aumenta, devido à maior exigència de renda. No caso das mulheres, a participação diminui. Entretanto, quando o número de filhas de treze anos ou mais aumenta, a participação da mulher no mercado de trabalho também aumenta, pois as filhas substituem os cuidados maternos. Outro resultado interessante refere-se ao aumento da renda não-salarial (aluguel, pensão, aposentadoria etc.). Quando aumenta a renda não-salarial há diminuição da participação no mercado de trabalho. As variáveis experiència e experiència ao quadrado foram incluidas para captar o efeito da depreciação do capital humano. Os resultados são positivos para a experiència e negativos para a experiència ao quadrado. Ou seja, quanto mais experiència adquirida, maiores são as oportunidades de emprego, até determinado ponto máximo. A partir dele, a participação começa a decrescer, refletindo a perda das habilidades pelo envelhecimento. Seu trabalho mostra também que um aumento no nivel de educação provoca aumento nos rendimentos, tanto no setor rural quanto no urbano, para ambos os sexos. Comparando os retornos da educação aos da experiência, constatou que a educação possui rendimentos superiores à experiência. Os rendimentos da educação mostraram-se aproximadamente duas vezes superiores no setor urbano em comparação ao rural.

A literatura dispõe de muitos trabalhos enfatizando os investimentos em educação e seus efeitos no mercado de trabalho. Um deles refere-se ao aumento da participação da mulher no mercado de trabalho. A esse respeito, Becker (1993) destaca que, nos Estados Unidos, o nível educacional das mulheres tem aumentado, em comparação ao dos homens. Isso talvez contribua para a explicação do aumento significativo da participação da mulher no mercado de trabalho. O autor aponta, ainda, uma associação positiva entre os rendimentos e o nivel de escolaridade. Nesse contexto, ressalta-se que pouca atenção tem sido dada à alocação do tempo dos trabalhadores fora do mercado de trabalho, isto é, aos trabalhos domésticos. Malathy (1994) desenvolveu 
uma pesquisa para medir a influència da educação nesse mercado. $\mathrm{O}$ autor estimou uma função de demanda para trabalhos domésticos, contendo, entre as variáveis explicativas, os salários das esposas e dos esposos, e o nível de educação. Seus resultados mostraram que o aumento da educação implica aumento dos rendimentos e diminuição do tempo disponivel para trabalhos domésticos, principalmente para as mulheres. Isto é, quanto mais aumenta a educação das mulheres, menos tempo elas dedicam às tarefas domésticas.

\subsection{Educação e o desenvolvimento agrícola}

Para o processo de crescimento econômico, o desenvolvimento da agricultura é um fator fundamental. Diversos trabalhos, entre eles o de Griliches (1957), apresentam a importància do aumento do nível tecnológico para elevar a quantidade produzida no setor agrícola. Juntamente com o crescimento dos niveis tecnologicos, está o aumento nos niveis educacionais face à elevação da demanda por trabalhadores mais qualificados. Nesse contexto, serão apresentados os trabalhos que tratam da educação no setor rural e seus efeitos.

Gisser (1965) tratou a questão da educação nos Estados Unidos, analisando seus efeitos sobre renda e mercado de trabalho. Segundo o autor, se houvesse elevação do nível escolar dos trabalhadores rurais, isso implicaria dois efeitos: efeito mobilidade e efeito capacitação. O primeiro é uma amplitude maior de opções de trabalho, fora do setor agrícola, proporcionada pelo melhor nivel de escolaridade. Já o segundo diz respeito a uma habilidade maior para execução de funções, adaptação a novas técnicas, bem como a uma capacitação maior dos trabalhadores para alocação otima dos recursos. O objetivo do estudo era mostrar que o aumento do nivel de escolaridade propiciava maior migração rural-urbana e superava o efeito de uma produtividade maior no setor rural. A metodologia utilizada foi a estimação de curvas de 
oferta e demanda por trabalhadores do setor agricola, obtendo as elasticidades e o uso da taxa interna de retorno (TIR). Os resultados do estudo mostram que um aumento de $10 \%$ no nivel de escolaridade na zona rural induziria a uma migração rural da ordem de 6 a $7 \%$, elevando o salário rural em $5 \%$.

As modificações ocasionadas pela educação no meio rural também foram estudadas por Welch (1970), que destacou que a educação dos trabalhadores contribui para o processo produtivo com très efeitos: a) efeito insumo-seleção: refere-se à capacidade de determinar quantidades e tipos de recursos a serem utilizados em um processo produtivo: b) efeito alocativo: capacidade de alocar corretamente os recursos disponiveis à produção; e c) efeito trabalhador: melhora da qualidade do trabalhador. Esses efeitos possibilitam o aumento da produção. da produtividade do trabalhador e de seus rendimentos.

O trabalho de Schultz (1975.a) relaciona a educação com a elevação média da produtividade em duas situações: condições tradicionais e modernas, nos Estados Unidos. Os resultados mostram que o incremento médio na produtividade depende do grau de modernização. Para cada quatro anos adicionais de estudos, o autor encontrou um aumento de $1,3 \%$ e $9,5 \%$ na produtividade, sob condições tradicionais e de modernização, respectivamente.

Lockeed et al. (1980) analisaram 37 conjuntos de dados discutidos em 18 estudos, correlacionando educação e produção de pequenos agricultores em 13 países da África, Europa e América Latina. Utilizaram o método de regressão múltipla. O efeito da educação foi positivo (significativo) nos 31 conjuntos de dados, sendo que o ganho médio estimado chegou a $7,4 \%$ na produtividade para cada quatro anos adicionais de educação formal.

Também estudando aumento de produção e produtividade ocasionados pela educação, Ram (1980) utilizou uma função de produção do tipo Cobb-Douglas, para os anos de 1961 e 1971, na agricultura da Índia. Os resultados contrariam outros estudos 
citados, apontando que o nivel educacional não se mostrou significativo para o aumento da produção agrícola indiana. Mais tarde, Ilha \& Lima (1989) estudaram os impactos da educação em pequenas propriedades agricolas em Minas Gerais. Utilizando-se também de um modelo de estimativa de função de produção do tipo Cobb-Douglas, e de outro modelo para medir o efeito total do trabalhador, dividido em efeito trabalhador e efeito insumo-seleção e alocativo, os autores encontraram resultados positivos para a educação em ambas as culturas, tradicional e moderna.

Thame et al. (1987) desenvolveram um trabalho com a finalidade de mensurar a contribuição da educação nos niveis de renda da população agrícola, bem como sua importància na migração para o setor não-agrícola no Brasil, utilizando a mesma metodologia de Gisser (1965). Os resultados encontrados pelos autores, com os dados de 1980, para a função demanda, apontaram uma elasticidade do valor do produto marginal do trabalho de 0,15 para escolaridade; e para os dados de 1970-1980, uma elasticidade de 0,04. Já para a função oferta, foram encontrados 0,31 e 0,28 , respectivamente, para os dados de 1980 e os do conjunto 1970-1980. A taxa interna de retorno (TIR) da educação encontrada para o ano de 1970 foi $29 \%$; e, para 1970-80, $33 \%$.

No que se refere às contribuições da educação na eficiència alocativa dos recursos, podem-se ressaltar os trabalhos de Huffman (1977 e 1980). No primeiro, o autor centrou seus objetivos na apresentação das evidências econométricas que os investimentos em educação e extensão apresentaram na agricultura dos Estados Unidos. O modelo utilizado consistia na estimação de uma função de demanda por fertilizantes nitrogenados. Os resultados encontrados mostraram uma contribuição positiva e significativa para a eficiência alocativa dos recursos. Ou seja, quanto maior a educação, maior a eficiência alocativa. No segundo trabalho, o autor preocupou-se com a alocação dos trabalhadores dentro e fora do setor agricola. Com o moderno crescimento econômico, muitas pessoas realocam seus recursos na tentativa de mudar suas condições econòmicas. Suas melhoras são atribuidas à habilidade alocativa. Nos Estados Unidos, as 
maiores realocações tèm sido feitas com a força de trabalho entre campo e cidade. Para atingir esses objetivos, o autor utilizou um modelo de maximização de uma função utilidade, sujeito a algumas restrições, $O$ coeficiente da educação e extensão dos trabalhadores do campo mostra-se conforme o esperado. Os resultados empíricos mostram que o trabalhador rural com mais educação, quando o mesmo não migra, tem realocado seus serviços para trabalhos autònomos e/ou fora do setor agricola. Portanto, parte do retorno da educação na zona agricola deve-se à alocação do trabalho entre os mercados de trabalho agricola e não-agricola.

Além dos trabalhos que se preocuparam em avaliar a influència da educaçào no processo produtivo, encontra-se na literatura um trabalho que mostra o impacto dos niveis educacionais após o processo produtivo. O estudo de Goodwin \& Schroeder (1994) analisa a importância da educação no processo de comercialização e gerenciamento dos riscos de mercado, via mercados futuros nos Estados Unidos. Seu objetivo consiste em avaliar a contribuição da educação na comercialização via mercados futuros, para um melhor gerenciamento dos riscos de mercado. O método utilizado foi a maximização de uma função lucro, dadas algumas restrições. Os resultados apresentaram-se positivos para a educação, mostrando que, quanto maior o nivel de educação, mais eficientemente os produtores procuram os mercados futuros para uma melhor proteção na comercialização.

\subsection{Educação, modernização da agricultura e migração rural-urbana}

Muitas pesquisas mostram que a educação possibilita o acesso a melhores postos de trabalho. Entretanto, quando os postos encontram-se fora do setor agricola, pode haver o efeito da migração (efeito mobilidade) ${ }^{18}$, provocado, em parte, pelos niveis

\footnotetext{
${ }^{18}$ Gisser (1965).
} 
educacionais, refletindo a intenção dos individuos em buscar melhores condições de rendimentos e, conseqüentemente, melhores padrões de vida. Assim, o estudo sobre o processo de migração rural-urbana faz-se necessário, pois suas causas encontram-se, entre outras, no processo de modernização da agricultura e/ou nos niveis educacionais. Por um lado, a modernização da agricultura provocou uma queda na demanda por trabalhadores com pouca qualificação. Por outro, os níveis educacionais criaram expectativas de melhores empregos no setor urbano. Portanto, a modernização e os niveis de educação constituiram condições favoráveis para a migração rural-urbana. $O$ estudo de Araújo et al. (1985) destaca que, em 1980, dos 119 milhões de pessoas residentes no Brasil. 49 milhões não eram naturais dos municipios onde residiam e. destas, 24 milhões migraram entre 1970 e 1980. Os autores constataram, também, que a migração implicou o aumento de produtividade média do trabalhador agrícola. No entanto, para o prosseguimento da modernização, houve necessidade de investimentos na capacidade dos recursos humanos na agricultura. Significa dizer que a modernização provocou o aumento de produtividade dos trabalhadores elevando seus rendimentos, mas também necessitou, para sua manutenção, fundamentalmente do desenvolvimento do capital humano.

No Brasil, o processo de migração aconteceu principalmente em função da modernização da agricultura nos anos 70. Em um estudo comparativo, Vera \& Alves (1985) destacam que, em 40 anos (de 1940 a 1980), a percentagem da população brasileira residindo no meio urbano elevou-se de $31,2 \%$ para $67,6 \%$. Nos Estados Unidos, foram necessários 100 anos para que tal número se elevasse de $30 \%$ para $70 \%$. Como efeito, o Brasil teve de aumentar sua produção por habitante no meio rural em $20,9 \%$ para compensar os efeitos da concentração urbana

Com o processo de modernização, o setor agricola apresentou várias modificações destacando-se, entre elas, a distribuição da terra e da renda. A esse respeito, já destacado anteriormente, Andrade (1989) desenvolveu seu estudo objetivando verificar essas inter-relações, encontrando como resultado uma associação positiva entre 
modernização e desigualdade de distribuição da terra (aumentando-se a modernização, eleva-se tal desigualdade). O autor mostra, também, uma associaçào positiva entre modernização e rendimento médio, além de uma associação negativa entre modernização e indice de pobreza.

Ainda sobre a modernização da agricultura, Del Grossi (1989) destaca inicialmente que o Paraná, nos anos 70, conheceu um acentuado processo de modernização no setor agropecuario. Seu trabalho, já destacado anteriormente, objetivou estudar como se deu a distribuição dos frutos da modernização. O autor observou correlação significativa e positiva entre renda média e desigualdade da distribuição da renda. Entretanto, os efeitos benéficos da modernização, propiciando o aumento da renda média, foram neutralizados pelo aumento da desigualdade da distribuição da renda. Destaca-se ainda que, tomando apenas a População Economicamente Ativa (PEA) no setor agrícola, houve redução de 250 mil pessoas no período de 1970-1980 (quase 20\% da população). O autor observou tal acontecimento em que o processo de modernização foi mais intenso. E concluiu que as regiões com maior uso de tecnologias modernas apresentaram renda média superior à das demais, bem como menor nivel de pobreza. No entanto, os aumentos das rendas geradas foram desiguais, causando elevação da desigualdade no campo.

Os efeitos descritos acima podem ser frutos do processo de crescimento e desenvolvimento econômico de um país. Para Black (1993), o processo de migração no desenvolvimento agrícola na serra do Alvão, norte de Portugal, foi visto como um processo necessário para a economia como um todo e para o próprio setor agrícola, destacando em seu estudo que, através do êxodo rural, a agricultura se moderniza, contribuindo na geração dos excedentes de capital e mão-de-obra e no aumento da produção de alimentos e matérias-primas, bem como no aumento da produtividade e, conseqüentemente, do rendimento médio dos trabalhadores agricolas. 
Os trabalhos descritos nesta seção indicam certa relação entre educação. modernização da agricultura e migração rural-urbana, aparentando ser um processo natural do desenvolvimento da agricultura e da economia como um todo. 


\section{MATERIAL E MÉTODOS}

Este capitulo descreve inicialmente a área de estudo compreendida pelo trabalho. Em seguida, apresenta a metodologia a ser utilizada, destacando as pressuposições feitas e o modelo proposto. Mostra também, de forma pormenorizada, como foram compostos os dados utilizados e discute as soluções encontradas diante de alguns problemas envolvendo a obtenção de certas variáveis necessárias ao trabalho

\subsection{O Estado do Paraná}

O Paraná é considerado um dos estados com agricultura de grande relevància no cenário nacional. Nos anos 70 , passou por profundas modificações, ocasionadas principalmente pelo processo de modernização da agricultura brasileira. Percebe-se, porém, certa escassez de trabalhos desenvolvidos relacionando a agricultura com modernização, migração rural-urbana, niveis de educação, renda e suas interrelações. Assim, acredita-se que o Estado do Paraná constitui-se em uma importante fonte de pesquisa, principalmente nos anos analisados (1970 e 1980). Esse periodo é considerado como sendo de grandes transformações na agricultura. Entretanto, tal período constitui-se em um fator limitante do trabalho por depender de dados dos Censos Demográfico e Agropecuário ${ }^{19}$. Para tanto, pretende-se destacar as características principais do Estado do Paraná de acordo com os objetivos propostos no trabalho.

\footnotetext{
${ }^{19}$ O Censo Demogrático é divulgado de dez em dez anos, sendo o último disponivel o de 1991: já o Censo Agropecuário é divulgado de cinco em cinco anos, sendo o último disponivel o de 1985.
} 
O Paraná possui $199.554 \mathrm{Km}^{2}$ e uma população de 8.443 .299 habitantes, sendo 6.192.976 residentes na zona urbana e 2.250 .323 na zona rural, divididos em 24 Microrregiões Homogèneas (MRH) (Fundação Instituto Brasileiro de Geografia e Estatistica - Censo Demográfico do Paraná, 1991).

Segundo Konzen \& Zapparoli (1990), o processo de ocupação do estado, a partir do século XVI, foi determinado pelos grandes ciclos: o do escravo-indigena, o do ouro, o do tropeirismo, o da erva-mate e madeira, o do café, e os mais atuais, de soja e pecuária. A esse respeito, Magalhães Filho (1996) destaca que os ciclos do ouro e do tropeirismo iniciaram seus predominios em meados e ultimo quarto do seculo XVII, respectivamente. O ciclo da erva-mate deu-se a partir do século XIX, enquanto que o madeireiro consolidou-se no inicio do século $\mathrm{XX}$, impulsionado principalmente pelas diminuições das importações de madeira ocasionadas pela Primeira Grande Guerra. O café, no final do século XIX e inicio do XX, destacava-se como um dos mais importantes ciclos da história do Estado do Paraná. Entretanto, a partir dos anos 60, o mesmo diminuiu sua importància relativa no PIB agricola, em função de geadas, secas e da queda acentuada dos preços. Em sua substituição, passaram a ganhar importància soja, trigo, milho, algodão, cana-de-açúcar e pecuária.

$\mathrm{Na}$ década de 70, o Paraná passou por modificações significativas que determinaram novas formas de crescimento econômico. Assumpção et al. (1990) apresentam dois padrões de desenvolvimento: o primeiro refere-se ao padrão histórico, através do qual a expansão e a localização da agroindústria eram estimuladas pelas regiões fornecedoras de matérias-primas. O segundo está relacionado às condições de adequação à produção de matérias-primas exigidas pelas agroindústrias. Como exemplo do primeiro, os autores destacam produção de óleos vegetais, beneficiamento de fibras, abate de animais e produção de couros. Como exemplos do segundo padrão, destacam-se sericicultura, stévia, cana-de-açúcar e laranja.

No contexto das modificações do padrão de desenvolvimento da agricultura paranaense, houve significativas mudanças nas áreas ocupadas com as 
principais culturas, como mostra a Tabela 3. Segundo Pereira \& Lugnani (1989), entre os periodos de 1974-75 e 1979-80, as culturas que mais se retrairam foram mandioca, amendoim e arroz, com variação percentual na área plantada de $-52,2 \%,-49,9 \%$ e $-28,0 \%$, respectivamente. Por outro lado, as culturas que mais se expandiram foram fumo, soja e cana-de-açúcar ( $168,5 \%, 59,9 \%$ e $27,9 \%$, respectivamente). Destaca-se que a soja faz parte de uma cultura intensiva em terra e capital e utiliza, relativamente, pouca mão-de-obra.

Tabela 3. Area média (em mil ha) ocupada com as principais culturas do Estado do Paraná e suas variações de 1974-1985

\begin{tabular}{|c|c|c|c|c|c|}
\hline \multirow[b]{2}{*}{ Cultura } & \multicolumn{3}{|c|}{ Ano } & \multicolumn{2}{|c|}{ Variação $(\%)^{n}$} \\
\hline & $197+-75$ & $1979-80$ & $198+-85$ & $197+-75 / 1979-80$ & $1979-80 / 108+-85$ \\
\hline Arroz & 496.4 & 357.2 & 197.3 & -28.0 & $-4+.8$ \\
\hline Feijão & 801.6 & 780.8 & $732 t$ & -2.6 & -6.2 \\
\hline Mandioca & 92.5 & +4.2 & 79.7 & -52.2 & 80.4 \\
\hline Algodão & $3+3.8$ & 311.4 & 431.1 & -9.4 & 38.4 \\
\hline Amendoim & 98.9 & +9.5 & 12.1 & -49.9 & -75.6 \\
\hline Café & 1.165 .3 & 915.9 & 627.5 & $-21 .+$ & -31.5 \\
\hline Milho & 2.016 .5 & 2.137 .6 & 2.389 .9 & 6.0 & 11.8 \\
\hline Soja & 1.485 .9 & 2.375 .6 & 2.187 .1 & 59.9 & -7.9 \\
\hline Pastagens & 3.299 .0 & $3.986 . \mathrm{I}$ & -- & 20.8 & -- \\
\hline Cana & 42.7 & 54.7 & 131.3 & 27.9 & 139.9 \\
\hline Fumo & 9.4 & 25.3 & 19.3 & 168.5 & -23.8 \\
\hline Batata & nd & 48.8 & 39.9 & -- & -18.1 \\
\hline
\end{tabular}

Fonte: Pereira \& Lugnani (1989)

(1) Elaborado a partir dos dados dos autores.

No periodo de 1979-80 a 1984-85, observa-se que a área plantada do amendoim retraiu-se significativamente $(-75,6 \%)$, seguida do arroz $(-44,8 \%)$ e do café $(-31,5 \%)$. Em contrapartida, as áreas das culturas que mais se expandiram foram as da cana-de-açúcar $(139,9 \%)$, seguidas das da mandioca e do algodão, com variações de $80,4 \%$ e $38,4 \%$, respectivamente (Tabela 3 ). Faz-se necessário enfatizar que as variações 
negativas da área media ocupada, principalmente para o periodo de 1974-75/1979-80, foram para as culturas tradicionais, enquanto as positivas, para as culturas consideradas modernas. Isso mostra também a evolução do nivel de modernização da agricultura paranaense nos anos 70 e 80

Essas modificações nas áreas cultivadas referem-se às transformações ocasionadas pelo processo de modernização da agricultura, colaboradas pelo uso do crédito rural. O Estado do Paraná, principalmente no inicio dos anos 70, apresentou significativa participação no uso do crédito rural, instituido no final dos anos 60 como incentivo à modernização (Tabela 4). De 1974 a 1976, o estado detinha em torno de $21 \%$ do crédito rural total, caindo moderadamente nos anos subseqüentes ate $1985(18,4 \%)$.

Tabela 4. Valores reais em credito destinado à atividade agricola do Brasil e do Paraná, participação percentual do Paraná no crédito agricola, taxa real de juros e subsídio concedido à atividade agrícola do Paraná

\begin{tabular}{|c|c|c|c|c|c|}
\hline \multirow[b]{2}{*}{ Anos } & \multicolumn{2}{|c|}{$\begin{array}{l}\text { Valor do credito rural } \\
\text { (em billoóes de CrS de } 1985 \text { ) }\end{array}$} & \multirow{2}{*}{$\begin{array}{l}\text { Participação do } \\
\text { Paraná no } \\
\text { crédito rural } \\
(\mathrm{em} \%)^{1 .}\end{array}$} & \multirow{2}{*}{$\begin{array}{l}\text { Taxa real de } \\
\text { juros }(\%) \text { do } \\
\text { crédito rural }\end{array}$} & \multirow{2}{*}{$\begin{array}{c}\text { Valor do } \\
\text { subsidio à } \\
\text { agricultura } \\
\text { (Cr\$ bilhões - } \\
1985 \text { ). }\end{array}$} \\
\hline & Brasil & Paraná & & & \\
\hline 1974 & +1.753 .7 & 8.903 .8 & 21.3 & -17.6 & 1.567 .10 \\
\hline 1975 & 59.613 .2 & 12.975 .7 & 21.8 & $-1+.4$ & 1.868 .40 \\
\hline 1976 & 61.806 .7 & 13.038 .2 & 21.1 & $-2+.3$ & 3.168 .30 \\
\hline 1977 & 60.192 .7 & 12.208 .6 & 20.3 & -19.9 & 2.492 .50 \\
\hline 1978 & 57.538 .2 & 10.633 .7 & 18.5 & -18.3 & 1.946 .00 \\
\hline 1979 & 71.259 .7 & 13.581 .5 & 19.1 & -33.4 & +.536 .20 \\
\hline 1980 & 76.186 .3 & 13.101 .8 & 17.2 & -+2.9 & 5.620 .70 \\
\hline 1981 & 69.461 .1 & $12.2+2.9$ & 17.6 & -28.0 & $3 .+28.00$ \\
\hline 1982 & 67.214 .7 & 12.052 .2 & 17.9 & -30.0 & 3.615 .70 \\
\hline 1983 & $51.2+8.4$ & 8.839 .8 & 17.2 & -23.0 & 2.033 .20 \\
\hline 1984 & $32.20+.1$ & 6.217 .4 & 19.3 & -5.0 & 310.90 \\
\hline 1985 & $+7.3+7.3$ & 8.720 .4 & 18.4 & -2.0 & 174.40 \\
\hline
\end{tabular}

Fonte: Pereira \& Lugnani (1989)

(1) Elaborado a partir de dados dos autores. 
Destacam-se tambem, como incentivos à agricultura, as taxas de juros negativas destinadas ao crédito rural, como forma de subsídios, além dos subsidios diretos concedidos ao setor agricola, também apresentados na Tabela 4 .

Dessa forma, com o processo de modernização da agricultura, aliado ao uso do crédito rural e dos subsídios, o Paraná apresentou um desempenho crescente do Produto Interno Bruto (PIB) nos anos 80 (Tabela 5). Ressalta-se que o PIB do Paraná manteve, praticamente durante todo o período, uma participação relativa de aproximadamente 6\% do PIB total, ao longo de 1980-1994.

Tabela 5. Produto Interno Bruto (PIB) do Brasil e do Paraná: proporção do PIB do Paraná em relação ao PIB do Brasil; PIB per capita do Brasil e do Paraná, 1980-1994

\begin{tabular}{|c|c|c|c|c|c|}
\hline \multirow{3}{*}{ Anos } & \multicolumn{5}{|c|}{ Produto Interno Bruto (PIB) } \\
\hline & \multicolumn{2}{|c|}{ Total" } & \multirow[b]{2}{*}{$\begin{array}{c}\% \\
(3) /(2)\end{array}$} & \multicolumn{2}{|c|}{ Per capita: } \\
\hline & $\begin{array}{c}\text { Brasil } \\
(2)\end{array}$ & $\begin{array}{c}\text { Paraná } \\
\text { (3) }\end{array}$ & & Brasil & Paraná \\
\hline 1980 & 213.4 & 14.3 & 6.7 & 1.799 .0 & 1.871 .3 \\
\hline 1981 & 225.3 & 15.2 & 6.7 & 1.863 .4 & 1.972 .2 \\
\hline 1982 & $2+1.9$ & 15.1 & 6.2 & 1.963 .0 & 1.936 .7 \\
\hline 1983 & $2+5.2$ & 16.1 & 6.5 & 1.951 .6 & 2.047 .7 \\
\hline 1984 & 271.1 & 18.0 & 6.6 & 2.116 .7 & 2.270 .5 \\
\hline 1985 & 304.5 & 19.8 & 6.5 & 2.332 .4 & 2.481 .2 \\
\hline 1986 & 337.4 & 20.0 & 5.9 & 2.535 .2 & $2 .+81.2$ \\
\hline 1987 & 361.7 & 23.1 & 6.4 & 2.666 .6 & 2.845 .0 \\
\hline 1988 & 378.5 & 25.4 & 6.7 & 2.737 .5 & 3.092 .8 \\
\hline 1989 & +12.8 & 26.1 & 6.3 & 2.929 .1 & 3.143 .1 \\
\hline 1990 & +17.1 & 25.1 & 6.0 & 2.902 .9 & 3.001 .4 \\
\hline 1991 & +36.8 & 26.0 & 5.9 & 2.982 .9 & 3.084 .1 \\
\hline 1992 & +49.9 & 26.9 & 6,0 & 3.013 .9 & 3.163 .3 \\
\hline 1993 & +84.8 & 30.1 & 6.2 & 3.186 .3 & 3.495 .9 \\
\hline 1994 & 531.0 & 33.2 & 6.2 & $3 .+23.5$ & $3.82+.1$ \\
\hline
\end{tabular}

Fonte: Gazeta Mercantil (1995)

(1) en USS Bilhões.

(2) em USS. 


\subsection{Considerações metodológicas}

A metodologia utilizada neste trabalho baseia-se no trabalho de Micha Gisser (1965), ressaltando-se que a mesma também foi aplicada, em estudos para o Brasil, por Thame et al. (1987). Faz-se necessário destacar que parte considerável dos trabalhos encontrados na literatura utilizou estimativas de funções de produção, geralmente do tipo Cobb-Douglas, ou taxa interna de retorno para quantificar a importància dos niveis educacionais no aumento do produto $\mathrm{e}$ da renda Alternativamente, Micha Gisser desenvolveu uma metodologia, em meados da década de sessenta, que fundamenta-se na estimativa de equações de oferta e demanda de trabalho.

Embora já tenham surgido modelos mais sofisticados com maior poder de detalhamento, o modelo de Gisser (1965) não está ultrapassado e se diferencia dos demais por possibilitar uma análise intramercado. Esse modelo trata dos efeitos diretos da educação em um sistema de equilibrio entre oferta e demanda dentro do mercado de trabalho. Para o uso da mesma, faz-se necessário apresentar algumas pressuposições, também ressaltadas pelos autores anteriormente citados. A primeira é a aceitação de equilibrio estável no mercado de trabalho, sendo o fator equilibrador a competição via salários ${ }^{20}$. Pressupõe-se também que haja incentivos à realocação de recursos e que a diferença de habilidades entre individuos reflita a diferença entre seus desempenhos. Os preços relativos têm papel fundamental nos modelos neoclássicos para aliviar a pressão sobre a demanda por recursos escassos e incentivar o uso de recursos abundantes e mais baratos.

Segundo Hayami \& Ruttan (1970), a substituição entre capital e trabalho é circunscrita pela rigidez do capital e por equipamentos existentes. No longo prazo, as restrições desaparecem e as relações de produção podem ser definidas pela função de

\footnotetext{
20 Segundo Cunha e Maia (1984), a existência de desemprego e vagas a serem preenchidas, em um nivel nãoexplicável pelas friç̧ões do mercado, põe em questão a existência de equilibrio no mercado de trabalho, via competição salarial. Entretanto. este trabalho não abarcará tal questão.
} 
produção neoclássica. As relações produtivas podem ser descritas por uma metafunção de produção (curva envelope) ${ }^{21}$, pois as restrições de produção são relaxadas e as proporções dos fatores, em resposta às mudanças em seus preços relativos, ajustam o processo produtivo ao longo da superficie de isoproduto da curva envelope, com a adoção de tecnologia moderna.

\subsubsection{O modelo}

O modelo 22 utilizado, baseado no trabalho de Micha Gisser (1965), ajusta funçōes de demanda e oferta e tem sua idéia básica representada pela Figura $\mathrm{I}$, onde $\mathrm{S}$ representa o nivel de salário dos trabalhadores do meio rural, $\mathrm{T}$ é a quantidade de força de trabalho empregada no mesmo setor, $\mathrm{O}_{0}$ e $\mathrm{O}_{1}$ são as curvas de oferta e $\mathrm{D}_{0}$ e $\mathrm{D}_{1}$, as curvas de demanda, em periodos distintos

Figura 1: Oferta e demanda por trabalhadores no mercado de trabalho rural<smiles>[SiH3]</smiles>

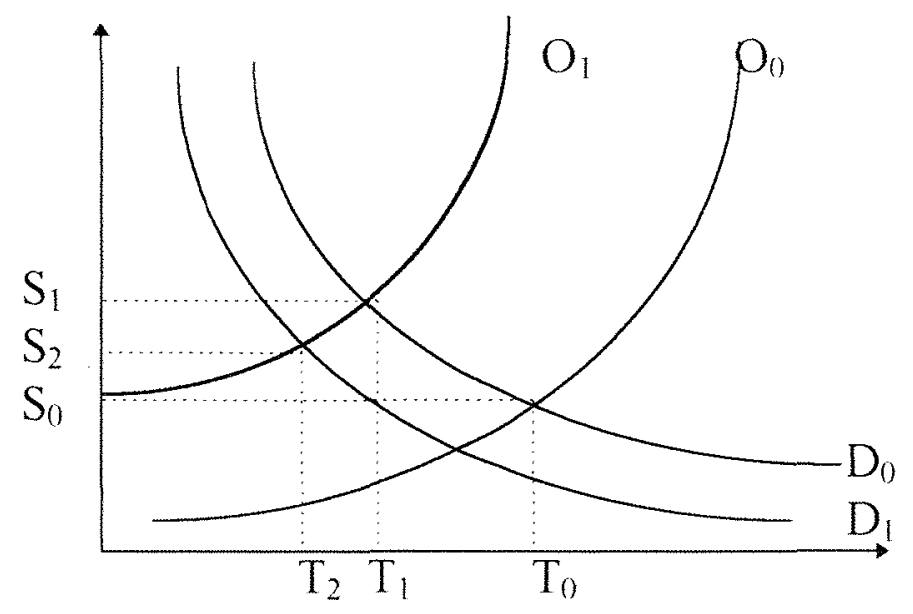

Fonte: Gisser (1965)

\footnotetext{
A esse respeito, ver Silberberg p. 190-207, (1978).

I2 Este modelo consiste na resolução de um sistema de equações simultâneas, utilizando-se. para a análise de regressão múltipla, o método dos minimos quadrados em dois estágios.
} 
O modelo supõe uma situação inicial em que o mercado de trabalho do setor agricola encontra-se em equilibrio, sendo ofertada e demandada a quantidade $T_{0}$ de mão-de-obra ao salário $S_{0}$. Suponha-se, agora, que os trabalhadores do setor rural recebem mais educação (de àmbito geral) e que tal acréscimo de educação thes forneça mais habilidade e destreza, propiciando-lhes dois efeitos: mobilidade e capacitação. O efeito mobilidade ${ }^{2 \Sigma}$, conforme apontado por Gisser (1965), propicia uma amplitude maior de opções de trabalho, fora do setor agricola, e isso reduz a oferta de mão-de-obra no setor rural. deslocando a curva de oferta de trabalho para a esquerda $\left(\mathrm{O}_{0} \text { para } \mathrm{O}_{1}\right)^{24}$. $\mathrm{O}$ outro efeito, capacitação ${ }^{25}$, possibilita maior habilidade na execução das funçōes, com melhor adaptação a novas técnicas de produção e alocação mais eficiente dos recursos disponiveis, mantendo a produção a despeito da redução da oferta de mão-de-obra. Esse efeito garante uma mesma quantidade de produção com o uso de uma quantidade menor de mão-de-obra, isto é, implica aumento da produtividade do trabalhador do setor agrícola. Sendo assim, além do deslocamento da curva de oferta de trabalho para $\mathrm{O}_{1}$ quando se considera o efeito capacitação, há também um deslocamento da curva de demanda por trabalho para $\mathrm{D}_{1}$, pois o custo por trabalhador torna-se mais elevado e uma quantidade menor de trabalhadores satisfaz as necessidades requeridas na produção. Assim, o salário dos trabalhadores do setor rural passa para um nivel maior, de $\mathrm{S}_{0}$ para $\mathrm{S}_{2}$, ou seja, situa-se em um nivel mais alto em comparação ao anterior, em função do aumento da produtividade do trabalho via escolarização e da redução da oferta de trabalhadores.

Como pressuposições do modelo, tem-se que: os salários rurais e as quantidades de pessoal ocupado observadas nas diferentes microrregiões do Estado do Paraná, são pontos de interseção entre demanda e oferta de mão-de-obra; os salários

\footnotetext{
${ }^{23} \mathrm{O}$ efeito mobilidade é a diferença entre a quantidade $T_{0} \mathrm{e} \mathrm{T}_{\mathrm{l}}$ em função do aumento da escolaridade

"A curva de oferta desloca-se proporcionalmente mais que a da demanda. pois está implícito que o valor do produto marginal do trabalho seja igual ao seu preço (salário). Logo, como teoricamente a educação eleva o valor do produto marginal do trabalho, espera-se um nivel de salários mais elevado.

${ }_{25} \mathrm{O}$ efeito capacitação é a diferença entre a quantidade de trabalhadores entre $\mathrm{T}_{1}$ e $\mathrm{T}_{2}$.
} 
rurais variam entre cada microrregião (as informações fluem livremente); o produto agricola pode ser representado por uma função de produção agregada. Admite-se ainda que a educação (qualquer nivel) aumenta as habilidades dos individuos e que tais habilidades contribuem para que os mesmos possam equacionar melhor os problemas, não só os escolares, mas também os de âmbito mais geral, e encontrar suas soluções. Isto é, a educação escolar propicia, além de conhecimentos escolares, conhecimentos gerais, e isso possibilita um aumento de sua renda, bem como a busca por melhores empregos, através da migração. Para verificar tal hipótese, são utilizados dois cortes seccionais, ajustando funçòes de oferta e demanda isoladamente para os anos de 1970 e 1980 e, por fim, as funçōes de oferta e de demanda para o conjunto 1970-1980 ("poof' $)^{26}$.

\subsubsection{As equações de demanda e oferta}

O modelo econométrico adotado neste trabalho especifica as quantidades demandadas e ofertadas de trabalho no meio rural do Estado do Paraná, através do seguinte sistema de equações:

$$
\begin{aligned}
& \text { Demanda } \quad \Rightarrow \quad S_{d}=a_{I} T^{a_{2}} C^{a_{3}} E^{a_{4}} A^{a_{5}} u \\
& \text { Oferta } \quad \Rightarrow \quad S_{0}=b_{1} T^{b_{2}} I^{b_{3}} E^{b_{4}} v \\
& \text { Demanda }=\text { Oferta } \quad \Rightarrow \quad S_{d}=S_{0}
\end{aligned}
$$

\footnotetext{
20 "Pool" é definido, entre outras, como comunhãa, isto é, uma combinação de recursos para obtenção de um
} objetivo comum, sendo, neste caso, uma combinação dos dados de 1970 e 1980. 
Colocando na forma logaritmica tem-se:

$$
\begin{aligned}
& \text { Demanda } \quad \Rightarrow \quad \ln S_{d}=a_{1}-a_{2} \ln T-a_{3} \ln C-a_{+} \ln E \cdots a_{5} \ln A-\ln u \\
& \text { Oferta } \quad \Rightarrow \quad \ln S_{i}=b_{l}-b_{2} \ln T-b_{3} \ln I-b_{+} \ln E-\ln v \\
& \text { Demanda }=\text { oferta } \quad \Rightarrow \ln S_{d}=\ln S_{i}
\end{aligned}
$$

Onde:

$\underline{S}_{\underline{I}}$ e $\underline{S}_{2}$ representam o nivel salarial médio no meio rural:

I representa o insumo força de trabalho;

C corresponde à variável capital:

$\underline{E}$ representa o nivel de escolaridade dos trabalhadores na atividade agricola;

$A$ indica a área cultivada por homem (área trabalhador);

I representa o salário dos trabalhadores da indústria da construção civil;

$\underline{\text { u }}$ e são termos aleatórios (erros aleatórios)

As variáveis anteriormente definidas foram medidas em logaritmos, de modo que os parâmetros estimados são as elasticidades. Assume-se que $C, E, I$, e $A$, são variáveis exógenas, isto é, determinadas fora do sistema de equações. Já $S$ e $T$ são variáveis endógenas do modelo. 
Na eq.(4), $a_{2}, a_{3}, a_{4}$, e $a_{5}$ são os coeficientes que medem a sensibilidade dos salários no Paraná às variações nas variáveis explicativas a eles associadas. Na eq.(5), $b_{2}, b_{3}$, e $b_{4}$ são, da mesma forma que na anterior, os coeficientes que medem a sensibilidade dos salários no Paraná às variações nas variáveis explicativas a eles correspondentes.

De conformidade com a teoria econòmica, em condições normais, esperase que os coeficientes apresentem os seguintes resultados:

Para a função demanda temos:

$$
\begin{aligned}
& a_{z}=\frac{\partial \ln S_{d}}{\partial \ln T} \quad 0 \\
& a_{z}=\frac{\partial \ln S_{d}}{\partial \ln C}>0 \\
& a_{+}=\frac{\partial \ln S_{d}}{\partial \ln E}>0 \\
& a_{5}=\frac{\partial \ln S_{d d}}{\partial \ln A}>0
\end{aligned}
$$

Como as variáveis incluídas na função demanda de trabalho serão medidas em logaritmos, as quatro equações acima serão as respectivas elasticidades.

Cabe ressaltar que as desigualdades anteriores são restrições teóricas. $\mathrm{Na}$ eq. (7), $a_{z}$ diz respeito à pressuposição usual sobre a inclinação negativa da curva de demanda por trabalho; na eq. (8), $a_{3}$ significa que o valor do produto marginal do trabalho aumenta quanto mais capital é aplicado ao processo produtivo; na eq. (9), $a_{+}$ indica que o valor do produto marginal do trabalho rural aumenta quanto maior for 0 grau de escolaridade dos trabalhadores; por fim, na eq. (10), $a_{5}$ aponta para um 
aumento no valor do produto marginal do trabalho a medida que se eleve a relação area trabalhador.

Para a equação de oferta temos:

$$
\begin{aligned}
& b_{z}=\frac{\hat{\partial} \ln S_{b}}{\partial \ln T}>0 \\
& b_{3}=\frac{\hat{C} \ln S_{u}}{\partial \ln I}>0 \\
& b_{+}=\frac{\partial \ln S_{u}}{\partial \ln E}>0
\end{aligned}
$$

Considerando situações normais, as très condições relativas à oferta também devem ser satisfeitas. Na eq. (11), $b_{2}$ representa a suposição sobre a inclinação positiva da curva de oferta de trabalho. Na eq. (12), $b_{3}$ mostra-se que o nivel da curva de oferta é mais elevado quanto maiores forem os rendimentos alternativos obtidos pelos trabalhadores do setor não-agricola. Já na eq. (13), $b$, demonstra que os trabalhadores com mais escolaridade possuem uma curva de oferta relativamente mais elevada ${ }^{27}$, aumentando os rendimentos à medida que aumenta o nível de escolaridade. A estimativa dos paràmetros desse sistema de equações simultàneas pode ser obtida através de regressão múltipla por Mínimos Quadrados em dois Estágios (MQ2E).

O método dos MQ2E consiste em uma técnica de estimativa de duas ou mais equações simultâneas em duas etapas distintas. A idéia básica é bastante simples e consiste em estimar a variável endógena (que aparece no lado direito das equações) do sistema em função das variáveis exógenas e predeterminadas. Ela constitui a primeira etapa do processo, também conhecida como primeiro estágio. Nessa etapa, elimina-se da variável endógena a parte correlacionada ao termo perturbação. A partir dai, cria-se um

\footnotetext{
${ }^{27}$ Esta atirmativa baseia-se na interpretação de que os trabalhadores rurais com grau mais elevado de escolaridade estão cientes de suas vantagens e em melhores condições de oferecer e vender seus serviços no setor não-agricola.
} 
novo conjunto de valores estimados para a referida variável, "livre" da correlação com o termo aleatório. $\mathrm{Na}$ segunda etapa (segundo estágio), as equações estruturais são estimadas em função da estimativa da variável endógena (que aparece no lado direito da equação) e das variáveis exógenas relacionadas a cada equação.

Para ilustração, nesse caso, tomam-se as eq. (4) e (5) do modelo proposto neste estudo, sendo $S$ e $T$ as variáveis endógenas, enquanto que $C, E, A$ e $I$ são exógenas:

$$
\begin{aligned}
& \text { Demanda } \Rightarrow \ln S_{d}=a_{1}-a_{2} \ln T-a_{3} \ln C-a_{+} \ln E \cdots a_{5} \ln A-\ln u \\
& \text { Oferta } \Rightarrow \ln S_{0}=b_{1} \cdots b_{2} \ln T-b_{3} \ln I \cdots b_{4} \ln E \cdots \ln
\end{aligned}
$$

A primeira fase consiste na estimativa, por Mínimos Quadrados Ordinários (MQO), da variável endógena (T) em função das demais exógenas do sistema de equações ( $\mathrm{C}, \mathrm{E}, \mathrm{A}$ e I). Isto é:

$$
\ln T=c_{1}-c_{2} \ln C-c_{3} \ln E-c_{f} \ln A-c_{5} \ln I-\ln z
$$

Essa estimativa elimina a correlação entre a variável $T$ e o termo perturbação $(u)$. A partir dela, cria-se um vetor $(\hat{T})$ com as estimativas isentas de correlação com o termo perturbação. Para a segunda etapa (segundo estágio), pode-se estimar as duas equações, por MQO, substituindo $\mathrm{T}$, das eq. (4) e (5), por $\hat{\mathrm{T}}$ e, dessa forma, serão obtidas as estimativas de parâmetros consistentes ${ }^{28}$.

$$
\begin{aligned}
& \text { Demanda } \Rightarrow \ln S_{d}=a_{1}-a_{2} \ln \hat{T}-a_{3} \ln C+a_{+} \ln E \cdots a_{5} \ln A-\ln u \\
& \text { Oferta } \Rightarrow \ln S_{0}=b_{1}-b_{2} \ln \hat{T}+b_{3} \ln I-b_{+} \ln E \div \ln \mathrm{l}
\end{aligned}
$$

\footnotetext{
${ }^{28}$ Um detalhamento desse metodo de estimativa pode ser encontrado em Kmenta (1994).
} 


\subsection{Fontes de dados}

Para a realização deste trabalho foi necessário, primeiramente, discutir as fontes de dados, bem como as variáveis que serão utilizadas. Os dados deste estudo foram encontrados, principalmente, nos Censos Agropecuários e Demográficos do Estado do Paraná, publicados pelo IBGE, referentes aos anos de 1970 e 1980. Além disso, foram utilizados também dados fornecidos pelo Instituto Paranaense de Desenvolvimento Econômico e Social (IPARDES). Este subitem mostra também as variáveis utilizadas e suas composiçōes, de forma mais abrangente, nos itens seguintes

\subsubsection{Salário rural (S)}

O salário rural (S) anual utilizado neste trabalho é a razão entre a soma dos salários mais quota-parte, e o número de trabalhadores. Os salários e a quota-parte ${ }^{29}$ são as remunerações recebidas pelos trabalhadores permanentes, temporários e parceiros. A quantidade de trabalhadores encontra-se desagregada em permanentes, temporários e parceiros. O salário, a quota-parte e o número de trabalhadores foram extraidos do Censo Agropecuário do Paraná nos anos de 1970 e 1980.

\subsubsection{Força de trabalho $(\mathrm{T})$}

A variável força de trabalho (T) é formada pela quantidade do pessoal ocupado ponderado pela equivalència-homem.

\footnotetext{
29 Os valores de 1970 toram transtomados em mil cruzeiros de 1980, utilizando-se o Índice Geral de Preços (IGP DI) da Fundação Getúlio Vargas.
} 
A quantidade do pessoal ocupado foi obtida atraves dos Censos Agropecuarios do Paraná de 1970 e 1980, e se encontrava subdividida em: a) responsaveis e membros não-remunerados da familia; b) empregados permanentes; c) empregados temporários; d) parceiros e, por fim, e) outra condição.

O procedimento para a definição de equivalència-homem ${ }^{30}$, descrito a seguir, obedeceu à seguinte ponderação:

a) homens com 14 anos ou mais $=1.00$

b) homens com menos de 14 anos $=0,50$

c) mulheres com 14 anos ou mais $=0.65$

d) mulheres com menos de 14 anos $=0,40$.

Para se chegar a esses valores relativos, buscaram-se, inicialmente, os valores primários sobre os rendimentos, sendo os mesmos encontrados no Censo Demográfico do Paraná de 1980, no volume Mão-de-Obra, referente a pessoas economicamente ativas, de 10 ou mais anos de idade, por rendimento médio mensal e sexo, segundo os setores de atividade e posição na ocupação. Os rendimentos dos trabalhadores (empregados) em atividades agropecuárias, de extração vegetal e de pesca mostraram-se inferiores, em torno de $35 \%$, para os trabalhadores do sexo feminino, em comparação aos do sexo masculino. Os dados referentes ao diferencial de rendimento de homens e mulheres com idade inferior a 14 anos foram obtidos informalmente nos sindicatos rurais (empregados e patronais) de Maringá e Curitiba, sendo que o sindicato patronal informou uma diferença maior entre crianças e adultos se comparada à informada pelo sindicato dos empregados. Os sindicatos confirmaram, ainda, o diferencial entre homens e mulheres - fornecidos pelo Censo Demográfico - baseado na remuneração recebida por produção.

\footnotetext{
${ }^{30}$ Os valores de equivalencia-homem foram definidos e utilizados nos estudos de Thame at al. (1987). Entretanto. os valores encontrados em seu trabalho diferem destes e são: $1,00,0,77,0,95,0,73$ para homens com 14 anos ou mais e abaixo de 14 anos, mulheres com 14 anos ou mais e abaixo de 14 anos, respectivamente.
} 


\subsubsection{Capital $(\mathrm{C})^{31}$}

A variável capital (C) foi obtida a partir de quatro subvariáveis. De maneira resumida, pode ser definida como a soma da remuneração do capital, da depreciação do capital e das despesas de custeio. Esse somatório é dividido pela área ocupada com as culturas plantadas nas microrregiões homogèneas do Paraná.

$$
C=\frac{[\mathrm{r}(\text { capital })-\text { Depreciação do capital }+ \text { Despesas de custeio }]}{\text { Area plantada }}
$$

Para obter as variàveis remuneração do capital e depreciação, foi necessário definir os itens que compõem capital. Este é formado pelos valores dos bens imóveis e de outros bens. O Censo Agropecuário do Paraná compõe os bens imóveis com os itens terras, prédios (residenciais e para outros fins), instalações e outras benfeitorias. Já na variável outros bens, inserem-se as culturas permanentes, matas plantadas, veículos e outros meios de transporte, animais (reprodução, criação etc.), máquinas e instrumentos agrários.

$\mathrm{Na}$ variavel remuneração do capital, utilizou-se uma taxa de juros real anual de 6\% referindo-se à taxa de poupança, nos anos de 1970 e 1980, correspondente ao custo de oportunidade do capital empregado no setor agricola. Essa taxa foi aplicada sobre o valor médio do capital. Para a definição da variável depreciação do capital, utilizou-se o método da linha reta. Esse método é largamente utilizado pelas empresas rurais e considera a depreciação como uma função linear da idade do bem. A fórmula do

\footnotetext{
${ }^{\text {I }}$ A definiçăo desta variavel baseia-se. em grande parte, em Thame et al. (1987).
} 
cálculo desse método é $\mathrm{D}=\frac{\mathrm{Va}-\mathrm{Vr}}{\mathrm{Vu}}$, onde $\mathrm{D}$ é a depreciação anual; $\mathrm{Va}$, o valor de aquisição dos bens de capital; Vr, o valor residual final; por fim, Vu é o tempo, em anos, da vida útil dos bens. Entretanto, neste trabalho considerou-se o valor residual dos bens igual a zero $(\mathrm{Vr}=0)$. Portanto, a depreciação fica resumida à razão entre o valor de aquisição e a vida útil do bem de capital.

No que diz respeito ao tempo de vida útil dos imóveis, buscou-se, de forma coerente, estabelecer os anos de vida útil dos imóveis, máquinas e instrumentos agrícolas utilizados por diversos órgãos ligados às empresas rurais. Quando em contato com vários desses órgãos (Banco do Brasil, Banestado, Emater-PR, Receita Federal), percebeu-se que não existe um critério único e bem definido para estabelecer o tempo de vida útil, mas sim, uma certa convenção, utilizada pelos principais órgãos ligados às atividades agrícolas que se diferenciam muito pouco em seus resultados. Dessa forma, considerou-se razoável e expressivo a adoção da convenção definida para os tempos de vida útil utilizados e fornecidos pela Emater-PR. Assim, para os imóveis, foram considerados 30 anos para prédios residenciais, 20 anos para instalações e benfeitorias e 10 anos para máquinas, instrumentos agrícolas e veículos.

A variável despesas de custeio consiste na soma dos gastos anuais com fertilizantes (adubo e calcário), defensivos (animal e vegetal), práticas de conservação do solo, consumo de energia elétrica (comprada), consumo de combustiveis (gasolina, lenha, óleo combustivel, óleo diesel, querosene, residuos vegetais, carvão vegetal, gás liqüefeito de petróleo, lubrificantes), sementes e mudas, inseticidas e fungicidas, alimentação e trato de animais (rações e medicamentos), serviços de empreitada, transporte da produção, impostos e taxas, e outras despesas. Somando-se os valores dessas variáveis, obteve-se o total das despesas de custeio. Por fim, a área ocupada com as culturas teve como fonte os Censos Agropecuários do Estado. Dessa forma, tem-se o capital (C) por hectare cultivado, para cada microrregião homogênea do Paraná, nos anos de 1970 e 1980. 


\subsubsection{Salário Alternativo (I)}

A variavel salário alternativo objetiva mostrar que o trabalhador rural possui uma alternativa fora do setor agrícola, de maneira que pode ser considerada como um custo de oportunidade para o deslocamento do trabalhador da zona rural para a urbana.

Para a composição do salario alternativo, tentou-se utilizar a média dos salários de pedreiros e serventes das principais cidades de cada microrregião do Estado do Parana. uma vez que o setor da construção civil foi um dos principais absorvedores de mão-de-obra advinda do campo, nas décadas de 70 e $80^{32}$. Para isso, foi enviada correspondência solicitando os rendimentos médios dos trabalhadores da construção civil nas principais cidades de cada MRH. As respostas enviadas continham, no entanto, os resultados da convenção da categoria, que estabeleceu salários iguais para todas as MRH. Logo, não foi possivel a realização de análises de regressão com essas informações.

$\mathrm{Na}$ tentativa de solucionar o problema, foi obtida, no IPARDES-PR, a renda interna por MRH por setores de atividades nos anos de 1970 e 1980. O setor industrial compreende os subsetores indústria extrativa vegetal, indústria da transformação, da construção civil, serviços industriais e serviços de utilidade pública. Segundo o IPARDES (1988), o subsetor da construção civil do Paraná compreendia, em $1970,26,3 \%$ do PIB a custo de fatores do setor industrial e, aproximadamente, 17,7\% em 1980. A participação relativa do setor da indústria da construção civil no PIB a custo de fatores do setor industrial, foi aplicada na renda do setor industrial ${ }^{\circledR}$. Dessa forma, obteve-se a renda da construção civil, nos anos de 1970 e 1980. Essa renda pertence aos

\footnotetext{
3 Segundo o SNDDUSCON (1995), em pesquisa realizada com os trabalhadores da construção civil da região metropolitana de Curitiba, em maio de 1995, dos trabalhadores que ingressaram nesse setor, 52,3\% eram provenientes da zona rural. Assim, acredita-se que, nas demais MRH do Paraná, na década de 70 , esse percentual apresentava-se bem superior ao encontrado em 1995

33 Faz-se a suposição de que a participação relativa da indústria da construção civil no PIB a custo de fatores também se dê. na mesma proporçào, para a renda do setor industrial do Paraná.
} 
proprietários dos fatores de produção. Entretanto, há necessidade de saber qual a proporção que remunera o fator trabalho. Para tanto, pesquisou-se e se encontrou informações, através do IBGE - Inquérito Especial - Indústria da Construção Civil para o ano de 1980 , sobre a participação do fator trabalho no PIB a custo de fatores para as unidades de federações, para o Brasil. Conhecido o percentualit do PIB a custo de fatores, pertencentes à classe dos trabalhadores, para o Estado do Paraná, aplicou-se o mesmo para cada microrregião homogènea, tanto para 1980 como para 1970

Informações relativas à quantidade de pessoal ocupado na indústria da construção civil, por MRH, foram encontradas no Censo Demográfico do Paraná de 1980, onde foram observadas quantidades referentes aos trabalhadores de 10 anos ou mais, por subsetor do setor industrial e, nesse, o da indústria da construção civil. No entanto, não foi possivel encontrar essa informação relativa ao pessoal ocupado, para o ano de 1970, pois a mesma não se encontra disponivel no Censo Demográfico de 1970 Entretanto, foi possivel encontrar as quantidades do pessoal ocupado, por sexo e por MRH, para o setor industrial como um todo. Dessa forma, admitiu-se que a relação proporcional dos trabalhadores, homens e mulheres, de 1980, da indústria da construção civil, em relação ao setor industrial, se aplicasse para 1970. Com essa suposição, foi possivel obter as quantidades de pessoas de 10 anos ou mais pertencentes ao setor da indústria da construção civil. A partir do pessoal ocupado e dos rendimentos por MRH, para ambos os anos, foi possivel obter o rendimento per capita dos trabalhadores da indústria da construção civil, considerado como um salário alternativo para trabalhadores rurais do Paraná.

\footnotetext{
${ }^{34}$ O percentual encontrado toi de $20,3 \%$ para o ano de 1980 , sendo o mesmo aplicado tambem para 1970 , haja vista a indisponibilidade dessa informação para o ulltimo ano.
} 


\subsubsection{Escolaridade (E)}

Os dados que se encontram disponiveis sobre escolaridade no Censo Demográfico do Paraná referem-se aos anos de 1970 e 1980, sendo que os mesmos contemplam os anos de estudo de toda a população, independentemente de zona rural ou urbana. Utilizando esses dados, podemos antecipar que os valores sobre escolaridade das zonas rurais nas $\mathrm{MRH}$, em que há predominància das atividades urbanas, serão superestimados. Isto é, espera-se que o grau de escolaridade nas regiões tipicamente agricolas seja menor do que nas regiões mais voltadas à industrialização. Entretanto, cabe ressaltar que, em 1970, 79\% das microrregiões homogêneas possuiam mais de $50 \%$ da população em atividades agrícolas. Já em $1980,62,5 \%$ das microrregiões possuíam mais de $50 \%$ da população residindo no setor rural. Contribuindo para a diminuição desse viés, acredita-se que muitas pessoas que residiam nas zonas urbanas desempenhavam atividades agrícolas no estado.

O Censo Demográfico do Paraná fornece o número de pessoas em seus respectivos anos de escolaridade. Entretanto, o trabalho necessita de um ano médio ponderado de escolaridade para cada microrregião. A idéia, a princípio, foi utilizar a Média Aritmética Ponderada $(M A P)$ sendo: $M A P=\frac{\sum x_{i} \cdot f_{i}}{\sum f_{i}}$, onde $x_{i}$ corresponde aos anos de escolaridade (peso) e $f_{i}$, às quantidades de pessoas em cada ano (freqüências). $\mathrm{O}$ menor peso foi zero, atribuído para pessoas sem instrução, enquanto o maior, 17, para as pessoas com 17 anos de estudos completados. Dessa forma, descrevem-se a seguir os pesos adotados: Pessoas sem instrução $=0$; sem declaração $=0,5^{35} ; \operatorname{com} 1$ ano $=1$; com 2 anos $=2 ; \operatorname{com} 3$ anos $=3 ;$ e assim sucessivamente ate com 17 anos $=17$. Utilizando-se

\footnotetext{
${ }^{35} \mathrm{O}$ peso atribuido as pessoas que não declararam a escolaridade $(0,5)$ foi estabelecido arbitrariamente, ressaltando que essas pessoas representavam apenas $0,06 \% \mathrm{em} 1970$ e $0,05 \% \mathrm{em} 1980$.
} 
essa metodologia, obteve-se os anos médios de escolaridade para cada microrregião homogènea do Estado do Paraná, para os anos de 1970 e 1980.

\subsubsection{Area/trabalhador (A)}

A variável área trabalhador (A) corresponde à razão entre a área ocupada pelas principais culturas permanentes e temporárias plantadas no Paraná e as quantidades de pessoas (homens e mulheres) ocupadas de forma permanente, temporária e em parceria. A primeira variável - a área - foi obtida nos Censos Agropecuários do Paraná e corresponde à área ocupada pelas culturas permanentes e temporárias plantadas nas MRH. Já a quantidade de pessoas ocupadas corresponde àquelas que desenvolviam seus trabalhos como assalariados e parceiros. Esta variável pode ser considerada como uma medida das inovações mecânicas havidas na agricultura, indicando que quanto maior a razão, maior a produtividade do trabalhador em cada MRH. 


\section{RESULTADOS E DISCUSSÕES}

Este capitulo tem como objetivo apresentar as variáveis destacando suas inter-relações. a fim de mostrar o cenário no qual aconteceram transformações expressivas na agricultura paranaense e. em seguida, explicitar os resultados obtidos com o modelo econométrico. Inicialmente, será feita uma análise das variáveis utilizadas, juntamente com outras informações que auxiliam na compreensão das mudanças nas décadas de 70 e 80 . A partir de então, serão analisados os resultados do modelo de regressão adotado e, posteriormente, far-se-á uma análise conjunta dos mesmos para a formulação de conclusões pertinentes aos dados observados.

\subsection{Descrição e análise das variáveis}

Será apresentado, primeiramente, o comportamento das variaveis para os anos de 1970 e 1980, bem como suas evoluções, relacionando-as com outras mudanças na estrutura agropecuária do estado. Em seguida, apresentar-se-ão algumas relações, que possam ter existido, entre salário rural e as demais variáveis que compõem o modelo de regressão. Embora possa parecer densa e até mesmo exaustiva, esta seção nos parece extremamente importante no que concerne à apresentação de cada variável, com o objetivo de explicitar algumas transformações havidas no estado. 


\section{a) Salário rural/ano}

A variável salário mural foi constituida pela razão entre os salários mais quota-parte e as quantidades de trabalhadores permanentes, temporários e parceiros. Percebe-se. por um lado, que tanto em 1970 como em 1980 a MRH Litoral Paranaense (269) apresentou um valor relativamente superior ao das demais (Tabela 6).

Tabela 6. Salario rural/ano e estatisticas selecionadas, por MRH. 1970 e 1980

\begin{tabular}{|c|c|c|c|c|c|c|c|c|c|}
\hline \multirow[b]{2}{*}{$\therefore$} & \multirow[b]{2}{*}{ Microrregiăo } & \multicolumn{2}{|c|}{ Salario miraliano } & \multirow[b]{2}{*}{$x_{0}$} & \multirow[b]{2}{*}{$x^{*}$} & \multirow[b]{2}{*}{ Microtegiào } & \multicolumn{2}{|c|}{ Salario murallano } & \multirow[b]{2}{*}{$l^{10}{ }^{3}$} \\
\hline & & 1970 & 1980 & & & & 1970 & 1980 & \\
\hline 268 & Curitiba & 28.018 .17 & +0.966 .90 & +6.2 & 280 & Kigodoeira de Lssai & 20.805 .34 & 53.665 .85 & 157.9 \\
\hline 269 & Litural Paranaunse & 110.300 .96 & 95.502 .32 & -13.4 & 281 & Corte $X$ de Londrina & 22.946 .33 & 40.405 .02 & 76.1 \\
\hline 270 & Ato Ribeira & 30.039 .69 & 20.049 .31 & -33.3 & 282 & Vorte $\therefore$ de Maringi & 32.301 .52 & 31.730 .32 & -1.8 \\
\hline 271 & Ato R. N. Paranaense & 8.863 .60 & 19.127 .01 & 115.8 & 283 & Vorte N. Paranavai & 35.703 .18 & 48.140 .94 & 34.8 \\
\hline 272 & Campos de Lapa & 26.402 .14 & 35.005 .97 & 32.6 & 284 & Sorte $\mathrm{A}$ Apucarana & 19.500 .45 & 37.046 .29 & 90.0 \\
\hline 271 & Camp. Ponta Grossa & 36.824 .27 & 33.759 .74 & -8.3 & 285 & Vorte N. Lmuarama & 30.416 .78 & +1.659 .23 & 37.0 \\
\hline 274 & Campos Jaguaniava & 14.504 .61 & 39.173 .52 & 170.1 & 286 & Campo Nourão & 21.109 .98 & +7.992 .82 & 127.3 \\
\hline 275 & São Mfateus do Sul & 97.485 .77 & 15.756 .31 & -83.8 & 287 & Pitanga & 17.567 .43 & 20.807 .91 & 18.4 \\
\hline 276 & Colonial do Irati & 21.467 .68 & 23.629 .32 & 10.1 & 288 & Extr. O. Paranactse & 24.953 .87 & 28.877 .29 & 15.7 \\
\hline 277 & Ho Lai & 17.357 .72 & 20.037 .32 & 15,4 & 289 & Sudoeste Paranacase & 16.287 .94 & 24.829 .68 & 52.4 \\
\hline 278 & Sorte V: Vens Braz & 18.406 .68 & 28.746 .89 & 56.2 & 290 & Campos Guarapuava & 25.627 .86 & 38.275 .59 & +9.4 \\
\hline \multirow[t]{4}{*}{279} & Sorte $\mathrm{V}$. Jacarezinho & 28.239 .35 & 38.773 .35 & 37.3 & 291 & Médio Iguaçu & 28.650 .60 & 28.585 .46 & -0.2 \\
\hline & Media & $30.57+.25$ & 35.522 .68 & 16.2 & & Falor minimo & 8.863 .60 & 15.756 .31 & \\
\hline & Variància & $559.38 \mathrm{E}-6$ & $266.67 \mathrm{E}-6$ & & & Valor maximo & 110.300 .96 & 95.502 .32 & \\
\hline & Desrio-Padrão & 23.651 .13 & 16.330 .03 & & & Coet Variação & $77.3^{\circ} \circ$ & $45.9^{\circ} \mathrm{o}$ & \\
\hline
\end{tabular}

Fonte: FIBGE - Censos Agropecuários do Parana 1970-1980; dados da pesquisa

(I) em mil cruzeiros de 1980.

Analisando os tipos de cultura predominantes, verificou-se que a mesma cultivou arroz, mandioca e milho ${ }^{36}$. Como são culturas que não demandam relativamente grande quantidade de trabalhadores, não se encontrou, assim, uma explicação satisfatória para o entendimento desses valores com essa análise ${ }^{i 7}$. Por outro lado, a MRH de Alto

\footnotetext{
So Anexo B.1.

Ressalta-se que a quantidade de trabalhadores verificada no Censo Agropecuario do Paraná ce relativamente baixa, implicando um alto valor do salário médio. Este problema será diagnosticado novamente na apresentação da arrea trabalhador, constituindo assim um dos fatores limitantes do trabalho, qual seja, erro na tabulação dos dados.
} 
Rio Negro Paranaense (271), em 1970, ficou com o menor salário rurat ${ }^{8}$. Em 1980, com menor valor, apresentou-se a MRH de São Mateus do Sul $(275)^{39}$.

De 1970 para 1980, no âmbito geral, o salário rural aumentou para a maioria das MRH do Estado do Paraná, (Tabela 6). As MRH com maior elevação foram Campos de Jaguariaiva (274), com 170,1\%; Algodoeira de Assai (280), com 157,9\%; e Campo Mourão (286), com 127,3\%. Esses aumentos nos salários rurais podem ser explicados pelo comportamento dos trabalhadores permanentes, temporários e parceiros, verificando-se que houve uma redução no número de trabalhadores ${ }^{+0}$ de 1970 para 1980 nas MRH de Campos de Jaguariaiva (274) e Algodoeira de Assaí (280), com 7,8 e 30,5\%, respectivamente. e um aumento $(21,9 \%)$ abaixo da média para a MRH de Campo Mourão $(286)^{41}$.

Por outro lado, as diminuições mais sensiveis do salário rural verificaramse (Tabela 6) nas MRH de São Mateus do Sul (275), Alto Ribeira (270) e Litoral Paranaense (269), com $83,8 \%, 33,3 \%$ e $13,4 \%$, respectivamente. Nessas très MRH, como já foi ressaltado, a elevação de trabalhadores permanentes, temporários e parceiros provocou uma redução no salário rural médio ${ }^{+2}$.

\footnotetext{
${ }^{3}$ Nessa MRH. verificou-se (Anexo B.2) que a cultura do milho correspondia a $64.3 \%$ da área plantada em 1970.

30 1970 para 1980, houve uma variação positiva mais que proporcional da quantidade de trabalhadores em relação aos salários pagos, diminuindo a razão do salario rural, contorme o Anexo B.4 e o Apêndice V.

tô Apendice VII.

"1) Destaca-se (Anexos B.4, B.7, B. 10) que Campos de Jaguariaiva (274) apresentou uma diminução da importância relativa da área cultivada com milho $(59,9 \%$ para $34,0 \%)$, face ao aumento das culturas de trigo $(3,6 \%$ para $14,3 \%)$ e soja (2,0\% para 18,6\%), contorme Anexo B.4. Algodoeira de Assai (280), conforme Anexo B.7, também diminuiu a importância relativa da área plantada com milho $(26.8 \%$ para $10.8 \%)$ e algodão $(33.3 \%$ para $26.0 \%)$ vis-á-vis o aumento substancial do trigo e soja ( $5,4 \%$ para $23,3 \%$ e $2,6 \%$ para $27,1 \%$, respectivamente). A MRH de Campo Mourão (286), conforme Anexo B. 10. diminuiu a importảncia relativa das áreas plantadas com o algodão $(16,4 \%$ para $8,4 \%)$, arroz (12,8\% para $2,3 \%$ ) e teijão $(16,2 \%$ para $5.1 \%)$, diante do aumento do trigo $(3,3 \%$ para $21,4 \%)$ e da soja $(9,0 \%$ para $42,6 \%)$.

42 Destaca-se também. que as culturas das MRH do Litoral Paranaense (269) e Alto Ribeira (270) praticamente năo variaram de 1970 para 1980 (Anexo B.1 e B.2). Na MRH de São Mateus do Sul (275), percebe-se uma elevação da área plantada de soja $(0,03 \%$ para $10.3 \%)$, tace à diminuição relativa nas áreas com as culturas de tẹjão (38,4\% para $36,4 \%$ ) e milho ( $51.7 \%$ para $44,4 \%$ ), conforme Anexo B. 4 .
} 


\section{a ) Força de trabalho (T)}

Esta variável foi representada pela quantidade do pessoal ocupado ${ }^{43}$, ponderada pela equivalència-homem. Tanto em 1970 como em 1980, as MRH do Extremo Oeste Paranaense (288) e do Litoral Paranaense (269) apresentaram maiores e menores valores, respectivamente, (Tabela 7). Na primeira, verificou-se a maior participação relativa da área plantada para a cultura do milho em 1970, sendo, em parte, substituída por soja e trigo em $1980^{44}$. Já em relação à MRH do Litoral Paranaense (269), em função dos tipos de cultura, apesar de o milho ser o principal produto plantado, sua quantidade representava um percentual pequeno diante das demais MRH do estado.

Tabela 7. Força de trabalho/ano e estatísticas selecionadas, por MRH, 1970 e 1980

\begin{tabular}{|c|c|c|c|c|c|c|c|c|c|}
\hline \multirow[b]{2}{*}{$x^{\circ}$} & \multirow[b]{2}{*}{ Microrregião } & \multicolumn{3}{|c|}{ Força de trabalho/ano } & \multirow[b]{2}{*}{$N^{\circ}$} & \multirow[b]{2}{*}{ Microrregião } & \multicolumn{3}{|c|}{ Força de trabalho ano } \\
\hline & & 1970 & 1980 & $1 \%$ & & & 1970 & 1980 & $\perp^{0} \%$ \\
\hline 268 & Curitibar & 41.737 & 45.143 & 8.2 & 280 & Ngodoeira de Assai & 31.051 & 21.966 & -29.3 \\
\hline 269 & Litoral Paranaense & 5.764 & 9.704 & 68.4 & 281 & Vorte $\mathrm{N}$ de Londrina & 133.160 & 90.006 & -32.4 \\
\hline 270 & Alto Ribeira & 8.812 & 12.556 & +2.5 & 282 & Yorte $\mathrm{V}$ de Maringa & 57.634 & 45.083 & -21.8 \\
\hline 271 & Ato R. \. Paranatnse & 14.204 & 13.094 & -7.8 & 283 & Vorte X Paranavaí & 68.444 & 59.862 & -12.5 \\
\hline 272 & Campos de Lapa & 17.682 & 21.664 & 22.5 & 284 & Vorte N Apucarana & 125.200 & 99.546 & $-20,5$ \\
\hline 271 & Camp Ponta Grossa & 22.476 & 36.362 & 61.8 & 285 & Vorte $\backslash$ C Cnuarama & 179.846 & 132.082 & -26.6 \\
\hline 274 & Campos Jaguariaiva & 11.898 & 14.815 & 24.5 & 286 & Campo Mourão & 157.939 & 113.978 & -27.8 \\
\hline 275 & São Mateus do Sul & 14.274 & 16.441 & 15.2 & 287 & Pitanga & 36.826 & 51.741 & 40.5 \\
\hline 276 & Colonial do Irati & 43.858 & 47.873 & 9.2 & 288 & Extr. Oeste Paranaense & 236.825 & 231.134 & -2.4 \\
\hline 277 & Ato Ivai & 34.242 & 43.315 & 26.5 & 289 & Sudoeste Paranatense & 146.498 & 170.628 & 16.5 \\
\hline 278 & Norte V. Vanc. Bráz & 54.628 & 56.833 & 4.0 & 290 & Campos Guarapuava & +1.494 & 58.317 & 40.5 \\
\hline \multirow[t]{4}{*}{279} & Sorte $Y$. Jacarezinho & 87.554 & 63.385 & -27.6 & 291 & Mèdio Iguaçu & 29.696 & 29.821 & 0.4 \\
\hline & Média & 66.739 & 61.889 & -7.27 & & Valor minimo & 5.764 & 9.704 & \\
\hline & Variancia & $396690 \mathrm{E}+4$ & $296870 \mathrm{E}+4$ & & & Valor maximo & 236.825 & 231.134 & \\
\hline & Desvio-Padrão & 62.983 & 54.486 & & & Coef. Variaçăo & $94.3^{\circ} 0$ & $88.0^{\circ} 0$ & \\
\hline
\end{tabular}

Fonte: FIBGE - Censos Agropecuários do Paraná 1970-1980; dados da pesquisa

\footnotetext{
t3. Corresponde aos trabalhadores responsáveis e membros não-remunerados da familia: cmpregados permanentes: temporários: parceiros; e, por fim, outra condição.

it Anexo C. 11
} 
Em uma análise sobre a evolução da variável de 1970 para 1980, verificouse que, em média. houve uma diminuição de 7,27\%. Por um lado, o decréscimo mais acentuado foi para a MRH de Norte Novo de Londrina (281), que passou de 133.160 para 90.006 trabalhadores em equivalente-homens, representando uma diminuição de $32,4 \%$, conforme Tabela 7. Essa informação pode estar indicando mudanças na pauta de produção agropecuária do estado ${ }^{+5}$. Por outro lado, a MRH com maior acréscimo de força de trabalho foi a do Litoral Paranaense (269), passando de 5.764 para 9.704 trabalhadores, representando um aumento de $68,4 \%{ }^{46}$.

\section{e) Capital}

Esta variável foi formada pela razão entre a soma da remuneração do capital, depreciação e despesas de custeio pela área das culturas ${ }^{47}$.

Analisando a variável capital no ano de 1970, destaca-se. por um lado, a MRH de Norte Novissimo de Paranavai (283), com o maior valor por área ${ }^{+8}$. Por outro, a MRH de Alto Ribeira (270) encontra-se com menor valor conforme a Tabela 8

Para 1980 , tem-se que o maior valor foi verificado na MRH do Litoral Paranaense $(269)^{49}$ e o menor, na MRH Alto Ivai (277). O aumento mais expressivo da variável capital foi para as MRH Litoral Paranaense (269) e Alto Ribeira (270), com $596,5 \%$ e $492,2 \%$, respectivamente ${ }^{50}$.

\footnotetext{
15 Percebe-se (Anexo B.7) uma diminuição da área plantada, principalmente com algodão, arroz. caté e milho (intensivos em mão-de-obra), lace ao aumento relativo da área cultivada com trigo e soja.

${ }^{\text {to }}$ Nessa MRH, praticamente năo houve mudanças nos tipos de cultura, confonne o Anexo B.1.

${ }^{5}$ As culturas destacadas pelo Censo Agropecuário são: algodão, amendoim, arroz, batata inglesa. cana-de-açúcar. feijào, mandioca. milho, trigo, soja, caté, laranja e uva.

18 Verificou-se que a cultura predominante em 1970) era o café (Anexo C.8).

${ }^{10}$ Constatou-se, no Apèndice VII, um baixo valor da área cultivada. Logo, o alto valor da razào capital/área tó influenciado pelo baixo valor da ärea.

${ }_{50}^{50}$ Analisando paralelamente os tipos de cultura, percebe-se que a MRH Litoral Paranaense (269) não apresentou mudanças signiticativas nas áreas, apresentando apenas uma redução nas áreas plantadas com anroz (37,9\% para $30,7 \%$ ) e mandioca $(27.4 \%$ para $20,7 \%$ ). lace a um aumento nas culturas da cana-de-açucar $(5,3 \%$ para $7.4 \%)$,
} 
Tabela 8. Capital/ano e estatísticas selecionadas, por MRH. 1970 e 1980

\begin{tabular}{|c|c|c|c|c|c|c|c|c|c|}
\hline \multirow[b]{2}{*}{10} & \multirow[b]{2}{*}{ Microrregião } & \multicolumn{3}{|c|}{ Capital/ano } & \multirow[b]{2}{*}{$x^{\circ}$} & \multirow[b]{2}{*}{ Microrteglăo } & \multicolumn{3}{|c|}{ Capital ano } \\
\hline & & 1970 & 1980 & $\perp^{0} o$ & & & 1970 & 1980 & $1_{0} \theta_{\alpha}$ \\
\hline 268 & Curitiba & 13.700 .94 & 44.500 .23 & 224.8 & 280 & Hgodoeira de Assai & 13.702 .39 & 23.223 .69 & 69.5 \\
\hline 269 & Litoral Paranaunse & 19.287 .28 & 134.333 .44 & 596.5 & 281 & Corte N Londrina & 24.102 .75 & 38.502 .21 & 59.7 \\
\hline 270 & Alto Ribeira & 2.745 .62 & 16.258 .24 & 492.2 & 282 & Vorte $\mathrm{N}$. de Maringa & 11.550 .53 & 21.843 .40 & 89.1 \\
\hline 271 & Ato R. N. Paranaense & +.516 .65 & 16.996 .52 & 276.3 & 283 & Torte N. Paranavai & 38.093 .83 & 127.591 .23 & 234.9 \\
\hline 272 & Campos de Lapa & 9.087 .43 & 29.752 .17 & 227.4 & 284 & Sorte N. Lucarana & 4.988 .60 & 17.996 .15 & 260.7 \\
\hline 271 & Camp. Ponta Grossa & 16.903 .89 & 30.584 .27 & 80.9 & 285 & Vorte N. Lmuarama & 12.945 .65 & 51.111 .30 & 294.8 \\
\hline 274 & Campos Jaguariaiva & 11.019 .96 & 25.048 .52 & 127.3 & 286 & Campo Mourào & 7.918 .23 & 16.269 .56 & 105.5 \\
\hline 275 & São Mateus do Sul & 3.945 .26 & 13.393 .56 & 239.5 & 287 & Pitanga & 4.959 .31 & 9.928 .50 & 100.2 \\
\hline 276 & Colonial do Irati & 5.190 .00 & $\{0.458 .80$ & 101.5 & 288 & Extr. O. Paranamse & 5.916 .62 & 16.742 .50 & 183.0 \\
\hline 277 & Nto lvai & 4.156 .76 & 9.120 .76 & 119.4 & 289 & Sudoeste Paranatuse & 3.878 .22 & 14.330 .05 & 269.5 \\
\hline 278 & Vorte 5 . Vence Bráz & 6.688 .11 & 20.586 .24 & 207.8 & 290 & Campos Ciuarapuava & 8.996 .80 & 15.989 .90 & 7.7 .7 \\
\hline \multirow[t]{4}{*}{279} & Vorte 1. Jacarezinho & 10.662 .03 & 24.621 .71 & 130.9 & 291 & $\triangle$ Cédio Iguaçu & 7.240 .67 & 21.416 .64 & 195.8 \\
\hline & Média & 10.508 .23 & 31.274 .98 & 197.6 & & Valor minimo & 2.745 .62 & 9.120 .76 & \\
\hline & Variancia & $63.56 \mathrm{E}+6$ & $1.05 \mathrm{E}-9$ & & & Valor maximo & 38.093 .83 & 134.333 .40 & \\
\hline & Desvio-Padrão & 7.972 .49 & 32.458 .60 & & & Coef Variaçăo & $75.8^{\circ} \circ$ & $103.70 \%$ & \\
\hline
\end{tabular}

Fonte: FIBGE - Censos Agropecuários do Paraná 1970-1980; dados da pesquisa

(1) em mil cruzeiros de 1980.

No que diz respeito à evolução da variável capital, observa-se, na Tabela 8, que todas as MRH apresentaram aumentos acima de 59\%, destacando-se a MRH do Litoral Paranaense (269), com 596,5\%. Isso leva à indicação de que houve, em praticamente todas elas, um aumento da intensificação do uso de capital $l^{5 l}$ e que isso pode ter contribuido para um aumento da mão-de-obra assalariada temporária ${ }^{52}$, fàce às transformações na agricultura paranaense.

teijào $(2,1 \%$ para $9,1 \%)$ e laranja $(0,6 \%$ para 4,4\%), contorme Anexo B. 1. A MRH de Alto Ribeira (270) apresentou uma redução na importancia relativa no cultivo do milho $(66,1 \%$ para $54,7 \%)$ diante do aumento de feijão $(29,4 \%$ para $38,0 \%)$ e de laranja $(2,0 \%$ para $3.8 \%)$, contorme Anexo B. 2 .

51 Destacam-se as MRH de São Mateus do Sul (275), Colonial do Irati (276). Pitanga (287), Extremo Oeste Paranaense (288) e Sudoeste Paranaense (289), com variações substanciais em máquinas e equipamentos, seguidas de aumentos na participação do cultivo de culturas mais intensivas em capital, como é o caso de soja, trigo, milho e cana-de-açúcar, conforme os Anexos A. B.4. B.10 e B. 11, respectivamente.

5 Apêndices V e VI. 


\section{d) Escolaridade}

Os anos medios de escolaridade não mostraram grandes variações, apresentando valores proximos da média para a maioria das MRH. Por um lado, destacase a MRH de Curitiba (268), que apresentou a maior média de escolaridade em $1970(4,1$ anos). Por outro, a MRH de Alto Ribeira, com a menor (0,86 anos). Para 1980, a MRH com maior média de escolaridade foi novamente Curitiba $(268)^{53}, \operatorname{com} 4,6$, enquanto a de menor média foi Alto Ribeira (270), com 1,4 anos. A variância e o desvio-padrão foram 0,52 e 0,72 , respectivamente, tanto para 1970 como para 1980 e o coeficiente de variação indicou uma menor dispersão relativa dos dados para o ano de 1980 (Tabela 9).

Tabela 9. Escolaridade e estatísticas selecionadas, por MRH, 1970 e 1980

\begin{tabular}{|c|c|c|c|c|c|c|c|c|c|}
\hline \multirow[b]{2}{*}{$x^{\circ}$} & \multirow[b]{2}{*}{ Microrregião } & \multicolumn{3}{|c|}{ Escolaridade } & \multirow[b]{2}{*}{$\mathrm{N}^{\mathrm{o}}$} & \multirow[b]{2}{*}{ Microrregião } & \multicolumn{3}{|c|}{ Escolaridade } \\
\hline & & 1970 & 1980 & $3 \%$ & & & 1970 & 1980 & $\Delta \sigma_{\sigma}$ \\
\hline 268 & Curitiba & 4.163 & 4,596 & 10,4 & 280 & Algodoeira de Assaí & 1,582 & 2,515 & 58.9 \\
\hline 269 & Litoral Paranaense & 2.700 & 3,433 & 27.1 & 281 & Vorte $\mathrm{N}$. de Londrina & 2,263 & 3,534 & 56.2 \\
\hline 270 & Alto Ribeira & 0.860 & 1.403 & 63,1 & 282 & Vorte N. de Maringá & 2.219 & 3,704 & 66.9 \\
\hline 271 & tho R. N. Paranaense & 1.546 & 2.236 & 44.7 & 283 & Vorte N. Paranavai & 1.770 & 2.895 & 63.6 \\
\hline 272 & Campos de Lapa & 2.622 & 3.230 & 23.2 & 284 & Norte N. Apucarana & 1.391 & 2.477 & 78.1 \\
\hline 271 & Camp. de Ponta Grossa & 2.980 & 3.541 & 18.8 & 285 & Vorte Nov. Lmuarama & 1.284 & 2.543 & 98.0 \\
\hline 274 & Campos de Jaguariaiva & 1.786 & 2.268 & 26.9 & 286 & Campo Mourão & 1.171 & 2.285 & 95,1 \\
\hline 275 & São Mateus do Sul & 2.157 & 2.715 & 25.9 & 287 & Pitanga & 1.093 & 1,734 & 58.6 \\
\hline 276 & Colonial do Irati & 2.337 & 2.940 & 25.8 & 288 & Extr. Oeste Paranaense & 1.774 & 2.930 & 65.2 \\
\hline 277 & Alto Ivai & 1.184 & 1.604 & 35,5 & 289 & Sudoeste Paranaense & 1,727 & 2.784 & 61.2 \\
\hline 278 & Yorte V. Vanc. Bráz & 1.417 & 2.191 & 54,6 & 290 & Campos Guarapuava & 1,832 & 2.702 & 40.7 \\
\hline \multirow[t]{3}{*}{279} & Norte V. Jacarezinho & 1.780 & 2.890 & 62.3 & 291 & Médio Iguaçu & 2.076 & 3.038 & 33,1 \\
\hline & Média & 1.917 & 2,758 & 43,9 & & Valor minimo & 0,86 & 1,40 & \\
\hline & Desvio-Padrão & 0.72 & 0.72 & & & Coef. Variação & $37.5 \%$ & $26.1 \%$ & \\
\hline
\end{tabular}

Fonte: FIBGE - Censos Demográficos do Paraná 1970-1980; dados da pesquisa

No que se refere à evolução da escolaridade, de 1970 para 1980, observase que todas as MRH do Paraná tiveram melhoras nos anos médios de escolaridade. Com

\footnotetext{
${ }^{53}$ Isso confirma nossa expectativa, qual seja, de que as MRH onde os niveis de atividades industriais foram maiores, também se apresentaram maiores os niveis de escolaridade.
} 
um aumento mais expressivo, destacam-se as MRH de Norte Novíssimo de Umuarama (285), passando de 1,3 para 2,5, e de Campo Mourão (286), passando de 1,2 para 2,3 anos de escolaridade, representando aumentos de $98,0 \%$ e $95,1 \%$, respectivamente. Por outro lado, com um aumento modesto, a MRH de Curitiba (268) passou de 4,2 para 4,6 anos de escolaridade, apresentando um crescimento de $10,4 \%$.

\section{e) Salário alternativo}

Esta variável foi introduzida no trabalho na tentativa de captar o poder de atração do setor urbano sobre os trabalhadores da zona rural. No entanto, na sua apresentação, será feita apenas uma análise das estatisticas básicas apresentadas na Tabela 10. Pelo fato de não termos evidências das relações com outras variáveis que não seja o salário rural, nos limitaremos às análises estatísticas para não cometermos falhas na tentativa de indicar relações com as variáveis de que dispomos.

Tabela 10. Salário alternativo ano e estatísticas selecionadas, por MRH, 1970 e 1980

\begin{tabular}{|c|c|c|c|c|c|c|c|c|c|}
\hline \multirow[b]{2}{*}{$N^{\circ}$} & \multirow[b]{2}{*}{ Microrregião } & \multicolumn{3}{|c|}{ Salário alternativo ano ${ }^{i 1\}}$} & \multirow[b]{2}{*}{$\mathrm{N}^{\mathrm{o}}$} & \multirow[b]{2}{*}{ Microrregião } & \multicolumn{3}{|c|}{ Salánio altemativo/ano ${ }^{(1)}$} \\
\hline & & 1970 & 1980 & $\nu^{\%} \alpha$ & & & 1970 & 1980 & $1 \%$ \\
\hline 268 & Curitiba & 23.680 .40 & 61.344 .67 & 159.1 & 280 & Algodoeira de Assai & 52.140 .67 & 49.518 .81 & $-5,0$ \\
\hline 269 & Litoral Paranaense & $5.618,18$ & 7.934 .57 & 41.2 & 281 & Vionte $\mathrm{N}$. de Londrina & 24.376 .33 & $31.168,22$ & 27,9 \\
\hline 270 & Alto Ribeira & 6.952 .25 & 24.775 .85 & 256.4 & 282 & Norte N de Maringá & 34.021 .52 & 35.578 .46 & 4,6 \\
\hline 271 & Alto R. N. Paranaense & 4.796 .66 & 7.205 .96 & 50.2 & 283 & Norte N. Paranavaí & 15.213 .43 & $23.808,62$ & 56,5 \\
\hline 272 & Campos de Lapa & 17.418 .30 & 23.037 .17 & 32.3 & 284 & Norte N. Apucarana & 15.452 .15 & 24.790 .55 & 60.4 \\
\hline 271 & Camp. de Ponta Grossa & 28.104 .49 & 59.862 .58 & 113,0 & 285 & Norte Nov. Umuarama & 24.410 .89 & $35.547,01$ & 45.6 \\
\hline 274 & Campos de Jaguariaiva & $44.104,26$ & $69.070,36$ & 56.6 & 286 & Canpo Mourão & 23.972 .57 & $21.932,86$ & $-8,5$ \\
\hline 275 & São Mateus do Sul & 11.005 .28 & 20.673 .89 & 87.9 & 287 & Pitanga & 25.032 .97 & $29.658,95$ & 18,5 \\
\hline 276 & Colonial do Irati & 26.879 .72 & 30.883 .28 & 14.9 & 288 & Extr. Oeste Paranaense & 8.634 .32 & $8.956,60$ & 3,7 \\
\hline 277 & Atto Ivai & $6.891,30$ & 11.347 .26 & 64.7 & 289 & Sudoeste Paranaense & $14.539,72$ & $15.256,64$ & 4,9 \\
\hline 278 & Norte V. Venc. Bráz & 7.731 .45 & $12.568,77$ & 62,6 & 290 & Canpos Guarapuava & 22.582 .57 & $34.948,43$ & 54,8 \\
\hline \multirow[t]{4}{*}{279} & Norte V. Jacarezinho & 17.333 .19 & $28.033,11$ & 61,7 & 291 & Médio Iguaçu & 49.015 .80 & $67.334,00$ & 37,4 \\
\hline & Média & 21.246 .18 & 30.634 .86 & 44,2 & & Valor minimo & 4.796 .66 & $7.205,96$ & \\
\hline & Variància & $176,35 \mathrm{E} \div 6$ & $342.18 \mathrm{E} \div 6$ & & & Valor máximo & 52.140 .67 & $69.070,36$ & \\
\hline & Desvio-Padrão & 13.279 .74 & 18.498 .08 & & & Coet. Variação & $62,5^{\circ}$ & $60.4 \%$ & \\
\hline
\end{tabular}

Fonte: FIBGE - Inquéritos Especiais - 1980; IPARDES (1988); dados da pesquisa

(1) em mil cruzeiros de 1980. 
Ressalta-se, inicialmente, que a MRH de Algodoeira de Assai (280), em 1970, apresentou maior valor da variável salário alternativo. O menor ficou para Alto Rio Negro Paranaense (271). A média encontrada para o estado foi $\operatorname{Cr} \$ 21.246,18$, enquanto o desvio-padrão ficou em Cr\$13.279,74, conforme Tabela 10.

Em 1980, verificou-se o maior valor para a MRH de Campos de Jaguariaiva (274), com $\operatorname{Cr} \$ 69.070,36$, enquanto o menor foi encontrado novamente na MRH de Alto Rio Negro Paranaense (271), com Cr\$ 7.205,96. O desvio-padrão para 1980 foi Cr\$ $18.498,08$, e o coeficiente de variação indicou uma menor disperção relativa dos dados para o ano de 1980 (Tabela 10).

\section{f) Área trabalhador}

A área trabalhador indica, a grosso modo, o grau de inovações mecânicas em cada MRH do estado. Logo, onde houver um alto valor desta razão, espera-se verificar uma maior participação das culturas modernas, sendo a recíproca verdadeira.

Em 1970, a maior razão árealtrabalhador observada foi para a MRH de São Mateus do Sul $(275)^{54}$, com 98,31 hectares por homem. Pelo lado oposto, a menor razão foi apresentada pela MRH de Norte Novo de Londrina (281), com 3,27 hectares por homem, sendo verificada, ainda, uma razão média de 27,23 (Tabela 11). No caso da MRH de Norte Novo de Londrina, confirma-se nossa expectativa, pois a cultura predominante em 1970 era o café ${ }^{55}$. Já em 1980, a MRH que apresentou o valor mais alto da razão áreatrabalhador foi Sudoeste Paranaense (289), com 35,33 hectares por

\footnotetext{
${ }^{4}$ Sugere-se certo cuidado na interpretação deste resultado, pois suspeita-se de erro na tabulação dos dados para a quantidade de trabalhadores em 1970 , conforme já destacado anteriormente.

55 Anexo B.7.
} 
homem $^{56}$. Por outro lado, a MRH de Norte Novissimo de Paranavaí (283) registrou apenas $1,95^{57}$

Tabela 11. Areatrabalhador ano e estatísticas selecionadas, por MRH, 1970 e 1980

\begin{tabular}{|c|c|c|c|c|c|c|c|c|c|}
\hline \multirow[b]{2}{*}{$x^{\circ}$} & \multirow[b]{2}{*}{ Microrregião } & \multicolumn{3}{|c|}{ Area trabalhador ano } & \multirow[b]{2}{*}{$\mathrm{N}^{\circ}$} & \multirow[b]{2}{*}{ Microrregião } & \multicolumn{3}{|c|}{ Area trabalhador ano } \\
\hline & & 1970 & 1980 & $\Delta \%$ & & & 1970 & 1980 & $\Delta \%$ \\
\hline 268 & Curitiba & 25,40 & 10,58 & -58.32 & 280 & Algodoeira de Assai & 7,07 & 16,79 & 137,34 \\
\hline 269 & Litoral Paranaense & 9.75 & 2.56 & -73.75 & 281 & Norte N. de Londrina & 3.27 & 6.06 & 85.47 \\
\hline 270 & Ato Ribeira & 47,70 & 7,12 & $-85,07$ & 282 & Norte $\mathrm{N}$. de Maringá & 16,90 & 11.20 & $-33,71$ \\
\hline 271 & Alto R. N. Paranaense & 16.72 & 12.97 & .22 .39 & 283 & Norte N. Paranavaí & 5.58 & 1,95 & $-65,11$ \\
\hline 272 & Campos de Lapa & 23.19 & 14.49 & -37.51 & 284 & Torte N. Apucarana & 20.44 & 11.26 & -44.93 \\
\hline 271 & Camp. Ponta Grossa & 13.72 & 11.58 & -15.62 & 285 & Yorte Nov. Umuarama & 16.08 & 5.43 & -66.22 \\
\hline 274 & Campos Jaguariaiva & 7.88 & 16.53 & 109.90 & 286 & Campo Mourão & 16.25 & 23,09 & 42.04 \\
\hline 275 & São Mateus do Sul & 98.31 & 14.14 & -85.61 & 287 & Pitanga & 38.85 & 24.55 & -36.80 \\
\hline 276 & Colonial do Irati & 49.86 & 27.56 & -44.72 & 288 & Extr. Oeste Paranaense & 42,77 & 33.63 & -21.38 \\
\hline 277 & Alto Ivai & 38,71 & 21.52 & -44.40 & 289 & Sudoeste Paranaense & 67.35 & 35,33 & -47.55 \\
\hline 278 & Norte V. Venc. Bráz & 17.89 & 13.53 & $-24,40$ & 290 & Campos Guarapuava & 38,07 & 25,21 & $-33,78$ \\
\hline \multirow[t]{4}{*}{279} & Norte V. Jacarezinho & 7.26 & 9.48 & 30.61 & 291 & Médio Iguaçu & 24.61 & 16.39 & .33 .42 \\
\hline & Mèdia & 27.23 & 15,54 & $-42,9$ & & Valor minimo & 3,27 & 1,95 & \\
\hline & Variància & 502.23 & 81.66 & & & Valor máximo & 98,31 & 35,33 & \\
\hline & Desvio-Padrão & 22,41 & 9.04 & & & Coef. Variação & $82.3 \%$ & $58.2 \%$ & \\
\hline
\end{tabular}

Fonte: FIBGE - Censos Agropecuários do Paraná 1970-1980; dados da pesquisa

Com relação à evolução dessa variável, percebe-se que a razão

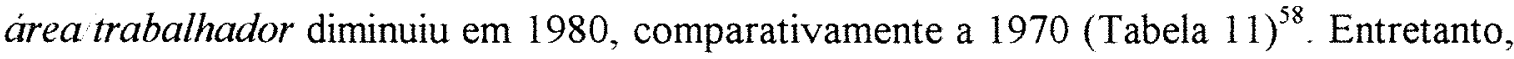
para as MRH de Campos de Jaguariaiva (274), Algodoeira de Assaí (280) e Campo Mourão (286), observa-se uma elevação da razão área trabalhador de 1970 para 1980 $(109,9 \%, 137,3 \% \text { e } 42,0 \% \text {, respectivamente })^{59}$.

\footnotetext{
${ }_{50}^{50}$ Verificou-se (Anexo C.11) uma grande participação das culturas de milho e soja, representando aproximadamente $75,0 \%$ da área plantada.

${ }^{57} \mathrm{O}$ café era a principal cultura, com $61,4 \%$ da área plantada (Anexo C.8).

${ }^{58}$ Analisando pormenorizadamente, observa-se que a variação positiva da quantidade de trabalhadores permanentes, temporários e parceiros (Apêndice VII) foi a principal responsável pela queda da razão áreaitrabalhador na maioria das MRH do Paraná. Observa-se também que, com exceção das MRH de Curitiba (268), Alto Ribeira (279): Alto Rio Negro Paranaense (271), Norte Novo de Apucarana (284) e Norte Novissimo de Umuarama (285), todas as demais tiveram variações positivas nas áreas plantadas com culturas temporárias e permanentes, em 1980, conforme os Anexos B.1 a B.12. Entretanto, na maioria das MRH onde houve aumento da área plantada, também foi verificado um aumento mais que proporcional dos trabalhadores permanentes, temporários e parceiros, implicando a diminuição da razão área/trabalhador.

59 Verificando o comportamento da razão área'trabalhador relacionado às áreas plantadas para as MRH que se destacaram com variações positivas, observa-se que Campos de Jaguariaiva (274), Norte Velho de Jacarezinho
} 
g) Análise descritiva entre as variáveis

A MRH do Extremo Oeste Paranaense (288), por um lado, apresentou, nos dois periodos analisados, as maiores quantidades de força de trabalho e, em contrapartida. salários rurais sempre abaixo da média. Por outro, a MRH do Litoral Paranaense (269) apresentou os maiores salários rurais e menores valores para a força de trabalho. Com a suposição de que um maior numero da força de trabalho poderia implicar salário rural menor, verificou-se que, em 1970, 50,0\% das MRH apresentaram sinais opostos simultaneamente. enquanto que. em 1980, esse percentual diminuiu para $33,3 \%$. Dessa forma. essa hipotese parece ser mais aceita para o ano de 1970

Fazendo-se uma analise conjunta da escolaridade com o salário rural, nota-se que houve certo grau de associação nos anos analisados. No ano de 1970, as MRH do Litoral Paranaense (269) e de Campos de Ponta Grossa (271), que apresentaram escolaridade (2,7 e 2,9, respectivamente) acima da média do Estado do Paraná $(1,9)$, tambèm possuiram salário rural acima da média. No que se refere à escolaridade abaixo da média. destaca-se que, a partir da MRH de Norte Novo de Apucarana (284) até a MRH de Campos de Guarapuava (290), ou seja, da 284 a 290, todas possuiam escolaridade e salário rural inferiores à média, ou seja, em $1970,66,7 \%{ }^{61}$ das MRH possuiam valores ou abaixo ou acima da media, simultaneamente, nas duas varáveis.

\footnotetext{
(279). Algodoeira de Assai (280). Norte Novo de Londrina (281) e Campo Mourão (286) tiveram aumentos da razão área mabalhador, e possuiram também um aumento no cultivo de culturas "modernas" em detrimento das "tradicionais". Arroz, milho, feijão (com exceção de Campos de Jaguariaiva (274)), caté (exceto Algodoeira de Assai (280) e Campo Mourão (286)) e algodão (com exceção de Algodoeira de Assai (280)) tiveram uma diminução relativa das áreas plantadas em fiução do aumento das culturas de trigo e soja (Anexos B).

¿ô Destaca-se ainda que, a partir da MRH Norte Velho de Jacarezinho (279) ate a Campo Mourão (286). apresentaram-se variações positivas no salário rural (com exceção de Norte Novo de Maringá (282)) e variações negativas na força de trabalho. Nessas MRH. foram veriticadas mudanças na pauta de produção agropecuária, com a substituição de culturas tradicionais pelas modernas (Anexos B.6 a B.10).

${ }^{-1}$ Esse percentual toi encontrado analisando-se as MRH que apresentavam valores acima ou abaixo da média com sinais positivos e negativos, respectivamente, para as duas variáveis em cada ano. A partir de então, foram veriticados sinais para cada $\mathrm{MRH}$ nas duas variáveis simultaneamente, extraindo-se a proporção em relação ao total.
} 
Em 1980, o destaque foi para as MRH de Curitiba (268), Norte Novo de Maringa (282), Campos de Ponta Grossa (271), Norte Novo de Londrina (281) e Litoral Paranaense (269), com 4,6, 3,7, 3,5, 3,5 e 3,4, respectivamente. Analisando o salário rural dessas MRH, observou-se que très ficaram acima da média do estado - Litoral Paranaense (269), Norte Novo de Maringá (282) e Campos de Ponta Grossa (271) -, sendo que as outras duas encontraram-se com o salário rural próximo à média. De outra forma, em 1980, verificou-se que $58,3 \%$ das MRH possuiam valores abaixo ou acima da média. simultaneamente, nas duas variáveis analisadas, representando uma relação diretamente proporcional.

Comparando o salário alternativo com o salario rural, nota-se que, em média, para os dois anos, o primeiro mostrou-se inferior em relação ao segundo. Verificou-se ainda que, em 1970, 45,8\% das MRH possuiam valores ou acima ou abaixo da média simultaneamente, indicando modesto valor de associação. Já em 1980, esse percentual aumentou para 62,5\%. Dessa forma, pode-se sugerir que o salário alternativo, representado pelo salário dos trabalhadores da indústria da construção civil, não se constituiu, em 1970, em uma força de atração para os trabalhadores rurais. Já em 1980, apresentou grau consideravel de associação. Entretanto, cabe frisar que esse setor possuiu grande importància no que se refere ao inicio dos trabalhos no setor não-agrícola, ou seja, como uma passagem quase que obrigatória para os trabalhadores rurais em busca de outros empregos nos demais setores da economia nos períodos subseqüentes à sua migração.

Em uma análise conjunta entre salcirio rural e capital, verificou-se a indicação de associação positiva, isto é, em boa parte das MRH onde o capital situava-se abaixo da média, também o salário rural encontrava-se com valores inferiores, tanto no ano de 1970 como em 1980. Da mesma forma, onde os capitais situavam-se acima da média, também os salários posicionavam-se superiores, ou seja, em 1970,66,7\% das MRH possuiam salário rural e capital acima ou abaixo da média simultaneamente. No ano de 1980 , esse percentual subiu para $70,8 \%$. 
Tomando como ponto de análise as médias do salário rural e a razão área trabalhador, percebeu-se que há uma associação entre as variáveis para a maioria das MRH do estado, principalmente em 1970. Nas MRH onde a razão área trabalhador situa-se abaixo da média, com frequêencia, o salário rural também encontra-se abaixo da média nos dois períodos analisados. Em outras palavras, verificou-se que o comportamento conjunto entre as variáveis área trabalhador e salário rural, em 1970, deram-se em $54,2 \%$ das MRH com valores acima ou abaixo da média simultaneamente. Já em 1980, esses valores apresentaram-se inferiores $(45,8 \%)$, não apresentando poder de associação significativo.

\subsection{Resultados do modelo econométrico}

De modo geral, ressalta-se, desde o início, que não foram detectados problemas sobre a possivel indicação de violação dos pressupostos básicos do modelo de regressão que pudessem prejudicar os resultados encontrados no trabalho.

No que se refere ao problema da escolha das variáveis, houve a indicação de que as mesmas contribuiram satisfatoriamente na especificação do modelo. No que diz respeito à heterocedasticidade, também não foram verificados, através da matriz de variància-covariância $^{62}$, problemas que pudessem afetar as estimativas confirmando a pressuposição de variância constante. Da mesma forma, observou-se que não houve indicios que apontassem autocorrelação de resíduos, através do teste de Durbin-Watson.

Entretanto, as estimativas de correlações entre as variáveis para os anos de 1970, 1980 e o conjunto 1970-1980 apresentaram um nivel significativo, principalmente entre as variáveis capital e área trabalhador para os três periodos analisados, indicando certo grau de multicolinearidade.

${ }^{62}$ Apèndice II. 
$\mathrm{Na}$ tentativa de solucionar esse possivel problema, foram sugeridas, por Kmenta (1994), algumas medidas descritas a seguir: a primeira diz respeito ao aumento do número de observações, mas isso não foi possivel, nesse caso, pelo fato de trabalharmos com microrregiões homogêneas, existindo apenas 24 no Estado do Paraná; a segunda seria a eliminação de uma das variáveis correlacionadas, para obtenção de um número maior de parâmetros estatisticamente significativos e, feito isso, ou seja, ora sem a variável capital, ora sem a variável área trabalhador, percebeu-se que o modelo tornouse não-significativo (teste "F"), bem como os paràmetros que, na sua maioria, apresentaram-se não-significativos (teste " $t$ ") a niveis inferiores a $10 \%$.

Analisando atentamente as regras de decisão nesses casos, Kmenta (1994) argumenta que grande parte das equações estimadas possui certo grau de multicolinearidade. A questão é saber qual magnitude desse grau deixa de ser normal e qual passa a ser prejudicial à estimativa. Não há, segundo o autor, consenso a esse respeito. Entretanto, o autor ainda sugere que existe um alto grau de multicolinearidade (prejudicial) quando as variáveis correlacionadas na estimativa provocam um valor de "F" significativo ao nivel de $5 \%$ para o modelo, e se nenhum dos parâmetros o for através do teste " $t$ ". Em outras palavras, a multicolinearidade é considerada aceitável se o valor de "F" for estatisticamente significativo a $5 \%$, juntamente com pelo menos um dos parâmetros estimados. Como alternativa, considera-se um grau de multicolinearidade nãoprejudicial ao modelo quando os parâmetros contribuem para a explicação da variável dependente, sendo significativos estatisticamente. Entretanto, percebe-se, neste estudo, que mesmo as variáveis capital e áreatrabalhador apresentando certo grau de multicolinearidade, as mesmas demonstraram contribuições para a explicação econômica do fenômeno estudado, optando-se por mantê-las, pois as mesmas possibilitam um melhor ajuste do modelo sob a luz da teoria econômica.

Conforme destacado no capítulo anterior, a metodologia de estimação de curvas de oferta e demanda deste trabalho foi utilizada inicialmente por Gisser (1965). Para um conjunto de observações referentes aos anos de 1950 e 1960, o autor encontrou 
coeficientes de elasticidade positivos para escolaridade, com um valor mais elevado para a equação de oferta. A equação de demanda apontou 0,47 enquanto a de oferta, 0,79 .

Para o Brasil, Thame et al. (1987) desenvolveram um estudo semelhante, sendo suas observações baseadas nos estados da Federação, nos anos de 1970, 1980 e no conjunto 1970-1980. Os resultados encontrados para as elasticidades da escolaridade foram, para $1980,0,15$ para a demanda e 0,31 para a oferta. Embora com valores relativamente menores para o Brasil, também foram verificados valores superiores para a equação de oferta, da mesma forma que os encontrados no trabalho de Gisser (1965) para os Estados Unidos. Para o conjunto de observações referentes a 1970-1980, verificou-se tambem o mesmo comportamento, ou seja, os valores das elasticidades para a curva de oferta $(0,28)$ foram superiores em comparação aos da curva de demanda $(0,04)$. Assim, nesse aspecto, o trabalho de Thame et al. (1987) confirma os resultados encontrados por Gisser (1965).

Fazendo uso da metodologia dos dois autores anteriores, este trabalho estima as elasticidades da escolaridade no setor agrícola do Paraná, nos anos de 1970, 1980 e no conjunto 1970-1980, utilizando as observações por microrregiões homogêneas. Além disso, dispõe também de uma análise descritiva, a fim de colher uma quantidade maior de subsidios no intuito de aumentar a confiabilidade dos resultados encontrados.

A seguir serão apresentados os resultados das estimativas das curvas de demanda e de oferta para os anos de 1970, 1980 e o "pool" 1970-1980. A exposição dos resultados será feita separadamente entre os períodos, iniciando-se pelo ano de 1970 e se distinguindo os paràmetros das equações de demanda e de oferta. Entretanto, no modelo de regressão adotado, alerta-se inicialmente que o conjunto de observações refere-se aos anos de 1970 e 1980 separadamente, caracterizando-se em dados "cross-section". Assim, ressaltamos que o modelo de regressão pode não apresentar bons ajustes, do ponto de vista estatístico, no que se refere ao coeficiente de determinação $\left(\mathrm{R}^{2}\right)^{63}$, como acontece

\footnotetext{
${ }^{03}$ Do ponto de vista estatístico, há também uma grande discussão sobre a contiabilidade da conclusão sobre os valores do teste " $t$ " para a estimativa de equações simultâneas. No modelo de regressão clássico normal,
} 
com a maioria dos trabalhos ${ }^{64}$ que usa esse tipo de dados, pelo fato de não apresentarem tendència para períodos sucessivos.

\subsubsection{Resultados para o ano de 1970}

Iniciando com os dados sobre as correlações entre as variáveis, observa-se, através da Tabela 12, que as mesmas são baixas e que somente a correlação entre as variáveis capital e escolaridade e capital e área trabalhador mostrou-se significativas ao nivel de $5 \%$.

Tabela 12. Matriz de correlações simples entre as variáveis salário mural (S), força de trabalho (T), capital (C), salário alternativo (I), escolaridade (E) e área trabalhador (A) para o ano de 1970

\begin{tabular}{lcccccc}
\hline & $\begin{array}{c}\text { Salário } \\
\text { rural }\end{array}$ & $\begin{array}{c}\text { Forçade } \\
\text { trabalho }\end{array}$ & Capital & $\begin{array}{c}\text { Salário } \\
\text { alternativo }\end{array}$ & $\begin{array}{c}\text { Escolaridade } \\
\text { Areatraba- } \\
\text { lhador }\end{array}$ \\
\hline Salário rural & 1.00 & -0.29 & 0.30 & -0.10 & 0.39 & 0.05 \\
Força de trabalho & & 1.00 & 0.10 & 0.21 & -0.16 & -0.07 \\
Capital & & & 1.00 & 0.37 & $0.50^{* *}$ & $-0.81^{* *}$ \\
Salário alternativo & & & & 1.00 & 0.24 & -0.27 \\
Escolaridade & & & & & 1.00 & -0.15 \\
Sreatrabalhador & & & & & & 1.00 \\
\hline
\end{tabular}

Fonte: Dados da pesquisa

** significativo a $5 \%$

No que diz respeito ao modelo, observa-se (Tabela 13) que, para a equação de demanda, o mesmo mostrou-se, através do teste " $F$ " ( $F=3,26)$, significativo a $5 \%$, com um $\mathrm{R}^{2}$ de 0,41 . Destaca-se ainda que não se verificou, através do teste de Durbin-Watson, autocorrelação dos resíduos.

pressupõe-se que as variáveis possuem distribuição normal Como a regressão por MQ2E necessita da estimativa de uma variável, é possivel que esta não tenha distribuição normal. Logo, o uso dos resultados dos testes " $t$ " pode não ser uma medida com o mesmo rigor do MQO. No entanto, neste estudo, serão usados os valores do teste " $t$ ". Uma discussão detalhada a esse respeito pode ser vista em Morimune (1989).

${ }^{64} \mathrm{O}$ trabalho de Thame (1987) apresentou um $\mathrm{R}^{2}$ de 0,38 para a demanda e 0,71 para a oferta no ano de 1980 . No conjunto 1970-1980, o $\mathrm{R}^{2}$ foi de 0,46 e 0,73 para a demanda e oferta respectivamente. 
Tabela 13. Resultados estatisticos da estimativa da demanda por força de trabalho, 1970

\begin{tabular}{llllcc}
\hline Variácel & Intercepto & $\begin{array}{l}\text { Força de } \\
\text { trabalho }\end{array}$ & Capital & Escolaridade & $\begin{array}{c}\text { Areatraba- } \\
\text { lhador }\end{array}$ \\
\hline Coeticientes da regressão & $5.944^{\text {n.s. }}$ & $-0.680^{\text {n.s. }}$ & $1.292^{*}$ & $-0.636^{\text {n.s. }}$ & $0.7+1^{*}$ \\
Valor de "t" & 1.415 & -1.464 & 2.666 & -1.059 & 2.757 \\
Nivel de significància & 0.17 & 0.16 & 0.01 & 0.30 & 0.01 \\
Valor de "F" & $3.26^{* *}$ & & & & \\
$\mathrm{R}^{2}$ & 0.41 & & & & \\
Durbin-Watson & 2.08 & & & &
\end{tabular}

Fonte: Dados da pesquisa

* significativo a 1\%:** significativo a $5 \%$ :*** significativo a 10\%: n.s. não-signilicativo.

No que se refere aos parâmetros estimados, verificou-se que somente os coeficientes do capital e da área trabalhador foram significativos. Os coeficientes das demais variáveis, embora não-significativos a niveis inferiores a $10 \%$, apresentaram os sinais esperados, com exceção da variável escolaridade. Para um aumento de $10 \%$ da variaivel capital, ter-se-ia um aumento de 12,9\% nos salários rurais. Da mesma forma, um aumento de $10 \%$ na razão área trabalhador ocasionaria uma elevação de $7,4 \%$ no valor do produto marginal do trabalho rural. Ressalta-se que não há como fazer comparações com os resultados de Thame et al. (1987), pois uma das suas equações (demanda) estimadas para 1970 apresentou-se não-significativa estatisticamente.

Para a equação de oferta, os resultados mostraram-se estatisticamente melhores em comparação aos da equação de demanda (Tabela 14). O modelo foi significativo $(F=4,17)$ a $1 \%$, com um $\mathrm{R}^{2}$ de 0,38 . Para essa equação, também não se apresentaram problemas de autocorrelação de residuos, verificado através do teste de Durbin-Watson.

Analisando os paràmetros estimados, observa-se que, com exceção da variável salário alternativo, todas tiveram seus sinais de acordo com o esperado, sendo também significativas estatisticamente a $1 \%$ e $5 \%$. 
Tabela 14. Resultados estatísticos da estimativa de oferta por força de trabalho, 1970

\begin{tabular}{lllcc}
\hline Variavel & Intercepto & Força de trabalho & Salánio altemativo & Escolaridade \\
\hline Coeticientes da regressão & $-8.604^{* * *}$ & $1.202^{* *}$ & $-0.626^{*}$ & $1.431^{*}$ \\
Valor de "t" & -1.782 & 2.482 & -2.683 & 3.482 \\
Nivel de significància & 0.08 & 0.02 & 0.01 & 0.01 \\
Valor de "F" & $+.17^{*}$ & & & \\
$\mathrm{R}^{2}$ & 0.38 & & & \\
Durbin-Watson & 2.217 & & & \\
\hline
\end{tabular}

Fonte: Dados da pesquisa

* significativo a $1 \%$ : ** significativo a $5 \%:{ }^{* * *}$ signiticativo a $10 \%$ : n.s. năo-significativo.

Um aumento de 10\% na quantidade ofertada de mão-de-obra só aconteceria caso houvesse um aumento de $12,0 \%$ nos salários dos trabalhadores rurais, ou seja, os trabalhadores só estariam dispostos a aumentar a quantidade ofertada da força de trabalho por um nivel maior de salários, ou seja, oferta positivamente inclinada. Da mesma forma, um aumento de 10\% nos niveis de escolaridade implicaria um aumento de $14,3 \%$ nos salários rurais, também de acordo com estudos realizados sob a luz da teoria do capital humano.

A variável salário alternativo, que representa os salários dos trabalhadores da indústria da construção civil, mostrou-se com o sinal contrário ao esperado, ou seja, $10 \%$ de aumento no salário alternativo, levaria a uma queda de $6,3 \%$ no salário rural. Isso indica que o setor da indústria da construção civil não serviu como fonte de atração, sobre os trabalhadores rurais, para os trabalhos desempenhados na cidade, confirmando as análises feitas através dos dados tabelados, no início deste capítulo, para o ano de 1970. A expectativa do sinal positivo para a variável salário alternativo fundamenta-se na hipótese de que o aumento dessa variável provoca a elevação da migração rural-urbana, diminuindo a quantidade ofertada de trabalhadores no setor agricola. Entretanto, cabe ressaltar que o setor da construção civil funcionou (funciona), em muitos casos, como uma passagem para outros empregos. Os trabalhadores que saem da agricultura, na grande maioria, empregam-se inicialmente no setor da construção civil e, posteriormente, em outros setores da zona urbana. 
Os resultados para o ano de 1970 podem ser resumidos destacando-se que, na equação de demanda, somente as variáveis capital e áreatrabalhador foram significativas estatisticamente, não apresentando assim o efeito capacitação. Já na equação de oferta, todas as variáveis foram significativas, demonstrando o efeito mobilidade atraves do deslocamento da curva de oferta para a esquerda, em função da escolaridade.

\subsubsection{Resultados para o ano de 1980}

Partindo para a análise sobre os dados de 1980, observa-se que, no geral, seus resultados mostraram-se semelhantes aos de 1970. Os indicadores de correlação são apresentados na Tabela 15. Ressalta-se que as correlações entre as variáveis salários e capital, salários e escolaridade, salários e áreatrabalhador, capital e escolaridade e, por fim, capital e área trabalhador, mostraram-se significativas a 5\%. Entretanto, as correlações entre salários e área trabalhador e capital e área trabalhador mostraram-se negativas, contrariando as expectativas iniciais. As demais correlações significativas encontram-se de acordo com o esperado, baseado na teoria econômica.

Tabela 15. Matriz de correlações simples entre as variáveis salários (S), força de trabalho $(\mathrm{T})$, capital (C), salário alternativo (I), escolaridade (E) éreatrabalhador (A) para o ano de 1980

\begin{tabular}{|c|c|c|c|c|c|c|}
\hline & $\begin{array}{c}\text { Salário } \\
\text { rural }\end{array}$ & $\begin{array}{l}\text { Força de } \\
\text { trabalho }\end{array}$ & Capital & $\begin{array}{c}\text { Salário } \\
\text { alternativo }\end{array}$ & Escolaridade & $\begin{array}{l}\text { Areatraba- } \\
\text { Ihador }\end{array}$ \\
\hline Salario rural & 1.00 & -0.01 & $0,73 * *$ & 0.26 & $0,48 * *$ & $-0.47 * *$ \\
\hline Força de trabalho & & 1.00 & -0.14 & -0.04 & 0.14 & 0.28 \\
\hline Capital & & & 1,00 & 0,06 & $0.51^{* *}$ & $-0,86 * *$ \\
\hline Salário alternativo & & & & 1.00 & 0.28 & 0,02 \\
\hline Escolaridade & & & & & 1.00 & -0.21 \\
\hline Irea trabalhador & & & & & & 1.00 \\
\hline
\end{tabular}

Fonte: Dados da pesquisa

** signiticativo a $5 \%$

Analisando-se a equação estimada da demanda para 1980, observa-se que o modelo é significativo estatisticamente ao nivel de $1 \%$ com o valor de "F" igual a 9,61 
(Tabela 16). O coeficiente de determinação $\left(\mathrm{R}^{2}=0,67\right)$ apresentou uma boa explicação, ou seja, $67 \%$ das variações nos salários rurais são explicados pelas variações no capital e na áréa trabalhador.

Tabela 16. Resultados estatísticos da estimativa da demanda por força de trabalho, 1980

\begin{tabular}{lccccc}
\hline Variável & Intercepto & Força de trabalho & Capital & Escolaridade & $\begin{array}{c}\text {. Area traba- } \\
\text { lhador }\end{array}$ \\
\hline Coeficientes da regressào & $6.628^{\text {n.s. }}$ & $-0.869^{\text {n.s. }}$ & $1.129^{*}$ & $0.197^{\text {n.s. }}$ & $0.958^{* *}$ \\
Valores de 'T" & 1.424 & -1.452 & 3.780 & 0.571 & 2.259 \\
Nivel de significância & 0.17 & 0.16 & 0.01 & 0.57 & 0.03 \\
Valor de "F" & $9.61^{*}$ & & & & \\
$\mathrm{R}^{2}$ & 0.67 & & & & \\
Durbin-Watson & 1.99 & & & & \\
\hline
\end{tabular}

Fonte: Dados da pesquisa

* significativo a $1 \%:{ }^{* *}$ significativo a $5 \%{ }^{* * *}$ significativo a $10 \%$ : n.s. não-significativo.

Os resultados assemelham-se aos de 1970, quando essas duas variáveis foram responsáveis por $41 \%$ das variações nos salários rurais. Da mesma forma que nas análises anteriores, destaca-se que não foi verificada autocorrelação dos residuos, através do teste de Durbin-Watson.

No que se refere aos parâmetros estimados, verificou-se que todos apresentaram os sinais esperados inicialmente. Entretanto, somente capital e área trabalhador mostraram-se significativos estatisticamente. Para a variável capital, tem-se que um aumento de $10 \%$ no volume de capital implicaria um aumento de $11,3 \%$ nos salários murais. Para a variável área/trabalhador, constatou-se que um aumento de $10 \%$ na relação área trabalhador implicaria um aumento de $9,6 \%$ nos salários dos trabalhadores rurais.

Analisando a equação estimada da oferta, observamos que o modelo foi significativo a $5 \%$, apresentando um valor de "F" de 2,81 (Tabela 17). No entanto, seu coeficiente de determinação $\left(\mathrm{R}^{2}\right)$ foi igual a $30 \%$. Também nessa equação não foi verificada autocorrelação dos resíduos, através do teste Durbin-Watson. 
Tabela 17. Resultados estatísticos da estimativa de oferta por força de trabalho, 1980

\begin{tabular}{llccc}
\hline Variável & Intercepto & Força de trabalho & Salário alternativo & Escolaridade \\
\hline Coeficientes da regressão & $5.798^{* *}$ & $-0.305^{\text {n.s }}$ & $0.050^{\text {n.s }}$ & $0.838^{*}$ \\
Valor de "t" & 2.032 & -1.144 & 0.393 & 2.553 \\
Nivel de signiticância & 0.05 & 0.26 & 0.69 & 0.01 \\
Valor de "F" & $2.81^{* *}$ & & & \\
$\mathrm{R}^{2}$ & 0.30 & & & \\
Durbin-Watson & 2.06 & & & \\
\hline
\end{tabular}

Fonte: Dados da pesquisa

* significativo a $1 \%$ : ** significativo a $5 \%: * * *$ significativo a $10 \%$ : n.s. não-significativo

No que se refere aos coeficientes estimados, observa-se sinal contrário ao esperado para a variável força de trabalho, sendo, porém, não-significativo estatisticamente, da mesma forma que para a variável salário alternativo. O coeficiente de elasticidade da escolaridade apresentou-se positivo, indicando que um aumento de $10 \%$ na escolaridade implicaria um aumento de $8,4 \%$ nos rendimentos dos trabalhadores rurais do Paraná, estando de acordo com a teoria do capital humano. Para essa equação, Thame et al. (1987) encontraram um coeficiente de elasticidade de 0,31, mostrando-se inferior ao verificado neste estudo $(0,84)$.

De forma sumarizada, o ano de 1980 apresentou somente as variáveis capital e área trabalhador, na equação de demanda, e escolaridade, na de oferta. Da mesma forma que, em 1970, ao contrário do efeito mobilidade, apresentado na equação de oferta, o efeito capacitação não foi verificado na equação de demanda.

\subsubsection{Resultados para o conjunto (Pool) $1970-1980$}

Foi feita uma análise conjunta ("pool") para 1970-1980, com a introdução de uma variável dummy com valor zero para o ano de 1970 e valor um para 1980, encontrando-se os resultados que serão apresentados a seguir. 
A matriz de correlação de Pearson apontou o grau de correlação entre as variáveis salário mural e capital, salário rural e escolaridade, capital e escolaridade e, por fim. capital e área trabalhador, estatisticamente significativos a 5\%. Entre eles, ressalta-se que a correlação entre capital e área trabalhador mostrou-se com o sinal contrário ao esperado inicialmente (Tabela 18).

Tabela 18. Matriz de correlações simples entre as variáveis salário nural (S), força de trabalho $(\mathrm{T})$, capital $(\mathrm{C})$, salário alternativo (I), escolaridade $(\mathrm{E})$, área trabalhador $(\mathrm{A}) \mathrm{e}$ dummy para ("Pool") 1970-1980.

\begin{tabular}{|c|c|c|c|c|c|c|c|}
\hline & $\begin{array}{l}\text { Salario } \\
\text { rural }\end{array}$ & $\begin{array}{l}\text { Força de } \\
\text { trabalho }\end{array}$ & Capital & $\begin{array}{l}\text { Salário } \\
\text { alternativo }\end{array}$ & Escolaridade & $\begin{array}{l}\text { trea rraba- } \\
\text { lhador }\end{array}$ & Dummy \\
\hline Salario rural & 1.00 & -0.17 & $0.54 * *$ & 0.12 & $0.49 * *$ & -0.22 & 0.27 \\
\hline Força de trabalho & & 1.00 & 0.01 & 0.09 & -0.03 & 0.07 & 0.02 \\
\hline Capital & & & 1.00 & 0.33 & $0.66 * *$ & $-0,80^{* *}$ & $0.61 * *$ \\
\hline Salärio alternativo & & & & 1.00 & 0.36 & -0.20 & 0.28 \\
\hline Escolaridade & & & & & 1.00 & -0.29 & $0.54^{* *}$ \\
\hline Areatrabalhador & & & & & & 1.00 & $-0,28$ \\
\hline Dummy: & & & & & & & 1.00 \\
\hline
\end{tabular}

Fonte: Dados da pesquisa

** signiticativo a $5 \%$.

Analisando-se o modelo de regressão para a curva de demanda (Tabela 19), percebe-se que o mesmo é altamente significativo ( $1 \%$ de significância), com o valor de "F" igual a 7,87 .

Tabela 19. Resultados estatísticos da estimativa da demanda por força de trabalho, ("Pool") 1970-1980.

\begin{tabular}{|c|c|c|c|c|c|c|}
\hline Variável & Intercepto & $\begin{array}{l}\text { Força de } \\
\text { trabalho }\end{array}$ & Capital & Escolaridade & $\begin{array}{c}\text { Area traba- } \\
\text { lhador }\end{array}$ & Dummy \\
\hline Coetícientes da regressão & $3.429^{1.58}$ & $-0.389^{\text {n.S. }}$ & $1.014^{*}$ & $-0.193^{\text {n.s. }}$ & $0,6+3^{*}$ & $-0.383^{* *}$ \\
\hline Valor de " $\mathrm{t}$ " & 0.726 & -0.731 & 3.218 & -0.579 & 2.532 & $-2,405$ \\
\hline Nivel de signifícància & 0.47 & 0.46 & 0.01 & 0.56 & 0.01 & 0.02 \\
\hline Valor de "F" & $7.87^{*}$ & & & & & \\
\hline $\mathrm{R}^{2}$ & 0.48 & & & & & \\
\hline Durbin-Watson & 2.00 & & & & & \\
\hline
\end{tabular}

Fonte: Dados da pesquisa

* significativo a $1 \%$ ** significativo a $5 \%$ ** * signilicativo a $10 \%$ : n.s. não-significativo. 
O coeficiente de determinação $\left(\mathrm{R}^{2}\right)$ apontou que $48 \%$ das variações nos salários rurais eram explicados pelas variáveis capital, área trabalhador e dummy. No que se refere à autocorrelação residual, ressalta-se que também não foi verificada nesse caso, através do teste de Durbin-Watson.

Referindo-se aos parâmetros estimados, verificou-se que somente a escolaridade possui sinal contrário ao esperado. O sinal negativo da força de trabalho indica a inclinação da curva de demanda. Entretanto, ressalta-se que os coeficientes estimados tanto para a força de trabalho quanto para a escolaridade mostraram-se nãosignificativos estatisticamente. O coeficiente estimado para a variável capital mostrou-se positivo, o que nos permite dizer que um aumento de $10 \%$ no volume de capital ocasionaria um aumento de $10,1 \%$ nos salários rurais dos trabalhadores. Da mesma forma, um aumento de $10 \%$ na relação área trabalhador implicaria aumento de $6,4 \%$ no valor do produto marginal do trabalho no setor rural. A variável dummy mostrou-se estatisticamente diferente de zero, indicando que, no ano de 1980, a equação estimada da demanda possuiu um intercepto relativamente menor comparado a 1970, sugerindo uma retração da demanda por trabalho.

Na equação de oferta (Tabela 20), nota-se que o modelo é altamente significativo a $1 \%$, com o valor de " $F$ " igual a 6,63 .

Tabela 20. Resultados estatísticos da estimativa da oferta por força de trabalho, ("Pool") $1970-1980$

\begin{tabular}{lccccc}
\hline & Intercepto & $\begin{array}{c}\text { Força de } \\
\text { trabalho }\end{array}$ & $\begin{array}{c}\text { Salário } \\
\text { altemativo }\end{array}$ & Escolaridade & Dummy \\
\hline Coeticientes da regressão & $-9,546^{*}$ & $1,212^{*}$ & $-0.234^{* *}$ & $0.929^{*}$ & $-0.054^{\text {n.s }}$ \\
Valor de "đ" & $-2,334$ & 3,072 & $-2,106$ & +.367 & -0.379 \\
Nível de significância & 0,01 & 0,01 & 0,03 & 0.01 & 0,70 \\
Valor de "F" & $6.63^{*}$ & & & & \\
$\mathrm{R}^{2}$ & 0,38 & & & & \\
Durbin-Watson & 1.77 & & & & \\
\hline
\end{tabular}

Fonte: Dados da pesquisa

${ }^{*}$ significativo a $1 \%$; ${ }^{* *}$ significativo a $5 \%{ }^{* * *}$ significativo a $10 \%$; n.s. não-significativo. 
Da mesma forma que na equação de demanda, o coeficiente de determinação apresentou-se relativamente baixo $\left(R^{2}=0,38\right)$. Pode-se também observar que não houve autocorrelação residual, conforme o teste de Durbin-Watson.

No que diz respeito aos parâmetros estimados, percebe-se sinal positivo do paràmetro para a variavel força de trabalho, de acordo com a teoria econômica sobre a inclinação positiva da curva de oferta. Os trabalhadores do setor agrícola só estariam dispostos a aumentar em $10 \%$ a quantidade ofertada da força de trabalho caso houvesse um aumento de $12,1 \%$ em seus salários. Para a variável salário alternativo, observa-se que. se a mesma aumentasse em $10 \%$ ocasionaria uma diminuição de $2,3 \%$ nos salários dos trabalhadores rurais. Isso pode estar sugerindo que o setor não-agrícola atrai relativamente pessoas mais qualificadas, diminuindo o valor do produto marginal do trabalho agricola. Já o paràmetro estimado da variável escolaridade apresentou-se positivo, indicando que um aumento de $10 \%$ nos niveis de escolaridade implicaria um aumento no valor do produto marginal do trabalho em $9,3 \%$, estando de acordo com a teoria do capital humano. O resultado encontrado por Thame et al. (1987) foi inferior $(0,28)$ em comparação ao verificado neste trabalho $(0,93)$.

Sumarizando os resultados do "pool" 1970-1980, verifica-se que as variáveis capital, área trabalhador e dummy, na demanda, foram significativas estatisticamente, não sendo verificado o efeito capacitação. Já na equação de oferta, o efeito mobilidade foi observado, pois as variáveis escolaridade, força de trabalho e salário alternativo apresentaram-se significativas estatisticamente. 


\section{CONCLUSÕES}

A nova exigència do mercado de trabalho por melhor qualificação mudou o perfil da demanda por trabalhadores. Várias empresas passaram a investir em qualificação da mão-de-obra, seja com capacitação, dentro ou fora das mesmas, seja com escolaridade formal. Dessa forma, neste estudo, verificou-se a importância da educação no que concerne à busca por melhores empregos e, também, à reivindicação de melhores rendimentos em função da maior produtividade dos trabalhadores.

Todavia, esse novo perfil do trabalhador mais qualificado, hoje explícito principalmente na zona urbana, mostra que o investimento em educação possibilita um aumento da produtividade dos trabalhadores e, consequentemente, de seus rendimentos. Entretanto, a hipótese deste trabalho é que tal fato não foi exclusividade da zona urbana. Também para o trabalhador rural, uma melhor qualificação foi requerida para combinar e alocar mais eficientemente os fatores de produção, principalmente no "periodo de modernização da agricultura".

Diante desse cenário, este estudo teve como objetivo principal testar aquela hipotese, qual seja, verificar se o grau de escolaridade formal dos trabalhadores rurais do Paraná teve importância na determinação de seus salários nos anos de 1970 e 1980. Através da análise descritiva, verificou-se que houve uma elevação dos níveis de escolaridade para todas as MRH do Estado do Paraná para o ano de 1980, comparado a 1970. Verificou-se também que a maioria das MRH do Estado do Paraná apresentou aumentos nos salários rurais associados a acréscimos nos anos médios de escolaridade. Ressalta-se que, além da escolaridade formal, muitos foram os fatores que contribuiram para a elevação dos salários rurais; entre eles, destaca-se o aumento no número de 
máquinas e equipamentos agricolas (inovações mecânicas), elevando, consequentemente a produtividade do trabalhador rural.

Analisando os resultados do modelo econométrico adotado, observou-se que, tanto para 1970, 1980 como para o conjunto 1970-1980, houve correlação positiva entre salários rurais e escolaridade, embora, em 1970, o coeficiente de elasticidade para a escolaridade apresentou-se não-significativo estatisticamente. Corroborando essa análise, destaca-se o fato de que, nas equações estimadas de oferta, a escolaridade apontou expressivos coeficientes de elasticidade, variando de 0,84 a 1,42 . Isso significa que o nivel de escolaridade possibilitou uma maior amplitude de opções de trabalho em outros mercados fora do setor agricola, ou seja, implicou o efeito mobilidade, isto é, implicou na redução da quantidade ofertada de trabalhadores rurais no Estado do Paraná. $\mathrm{Na}$ equação de demanda, os resultados apresentados não foram satisfatórios, pois todos os parâmetros foram não-significativos estatisticamente, demonstrando que o efeito capacitação não foi observado para os trabalhadores do estado, nos anos analisados. Dessa forma, os resultados nos induzem a concluir que, pelo fato da baixa escolaridade em todo o estado, os empresários agricolas foram indiferentes ao contratar trabalhadores com maiores ou menores niveis de educação, haja visto que a diferença foi muito pequena e aparentemente não possuiu reflexos perceptiveis nos niveis de produtividade.

Essa superioridade da equação de oferta confirma os resultados dos estudos anteriores elaborados por Gisser (1965) e Thame et al. (1987), ou seja, a escolaridade apresentou-se importante na equação de oferta indicando predomínio no que se refere ao efeito mobilidade comparado ao efeito capacitação. Uma análise conjunta utilizando os resultados da análise descritiva e do modelo econométrico adotado nos permitiu concluir que, mesmo com as diversas transformações e indefinições nas estruturas produtiva, fundiária e no mercado de trabalho, principalmente no ano de 1970 , a escolaridade apresentou importante papel na determinação dos rendimentos dos trabalhadores rurais do Paraná, nos anos de 1970 e 1980 . O fáto de o efeito capacitação não ter sido significativo estatisticamente, neste caso, não diminui a importância da 
educação no setor agrícola no que compete ao aumento da produtividade e dos salários rurais, sugerindo sim mais investimentos em educação, buscando efeitos positivos no que concerne à mobilidade, e à capacitação dos trabalhadores.

A esse respeito pode-se destacar que, em 1970, o Paraná investiu aproximadamente $2,0 \%$ do PIB em educação. Já em 1980, o estado investiu 2,7\%, ficando abaixo das médias da região sul $(2,8 \%)$ e do Brasil (3,3\%). Em 1990, o Estado aumentou o investimento para $4,4 \%$ do PIB, mas permaneceu abaixo das médias da região sul e do Brasil (4,5\% e 5,7\% respectivamente), segundo o Relatório sobre o Desenvolvimento Humano no Brasil (1996). Entretanto, faz-se necessário, não só continuar aumentando os investimentos em educação formal como também investir em qualificação técnica aos trabalhadores rurais, permitindo que os mesmos possam aumentar sua produtividade e renda, fixando suas atividades no setor agrícola. Significa dizer que os investimentos em qualificação técnica, fornecidos por agrônomos, técnicos agrícolas, etc., poderiam provocar o efeito capacitação sem implicar o efeito mobilidade. Esta seria uma medida de política educacional que aumentaria os rendimentos dos trabalhadores agrícolas, amenizando possivelmente, vários problemas sociais nos grandes centros, ocasionados, principalmente, por um grande número de trabalhadores que aparentemente não encontram trabalho em função de seus baixos niveis de escolaridade.

No que se refere aos resultados encontrados acerca da contribuição do salário alternativo para o processo de migração rural-urbana, ressalta-se que o mesmo mostrou-se com modesta atração na análise descritiva. Destaca-se, no entanto, que houve um acréscimo dos salários alternativos para a maioria das MRH do Estado em 1980 comparado com 1970. Entretanto, os níveis dos salários alternativos, tanto em 1970 como em 1980, foram inferiores aos niveis dos salários rurais sugerindo insuficiência do poder de atração por parte do setor não agrícola, através desta variável. Nas estimativas das equações de oferta, pôde-se perceber, no ano de 1970, o sinal contrário ao esperado inicialmente. No ano de 1980 e no conjunto 1970-1980, mesmo com os sinais esperados inicialmente, constatou-se que os coeficientes de elasticidade foram relativamente baixos. 
Assim, os resultados indicam que o poder de atração do salário alternativo, representado pelo salário dos trabalhadores da indústria da construção civil, apresentou-se insuficiente, no que concerne ao processo de migração rural-urbana para os trabalhadores do Paraná nos anos de 1970 e 1980.

Aparentemente, houve outros fatores que explicaram a saída de trabalhadores do setor agrícola para o não-agrícola, além dos salários que receberiam na construção civil. Entre eles, talvez a modernização da agricultura, com a incorporação de máquinas e equipamentos, bem como as mudanças nos tipos de cultura, expliquem melhor a migração rural-urbana. Entretanto, ressalta-se ainda que o setor da indústria da construção civil, em muitos casos, funciona como uma importante passagem (primeiro emprego) dos trabalhadores que saem do campo a caminho da zona urbana, ou seja, empregam-se inicialmente na construção civil e continuam buscando emprego em outros setores. Estes setores, por sua vez, possuem niveis semelhantes de qualificação exigido, porém requer menos esforço físico para execução de suas tarefas.

Com relação à variável capital, observou-se, na análise descritiva, um aumento expressivo de máquinas e equipamentos agrícolas, principalmente nas MRH onde vieram a predominar as culturas "modernas". Examinando-se a evolução desta variável constatou-se uma elevação expressiva para o ano de 1980 comparado com 1970. verificou-se que todas as MRH tiveram aumentos do capital por área, sendo que as proporções maiores foram verificadas para as MRH que apresentaram maiores mudanças na pauta de cultivo de culturas mais intensivas em capital. Onde houve um aumento de culturas modernas, em relação as tradicionais, verificou-se uma grande evolução da razão capital por área.

No que se refere ao modelo adotado, verificou-se uma correlação sempre positiva entre capital e salário rural, com valores bem mais elevados para o ano de 1980 confirmando a importância do capital para o aumento dos salários rurais. Da mesma forma, os coeficientes de elasticidades apresentaram-se, nos três períodos analisados, com 
significativo poder de implicação sobre o salário rural, destacando-se que as mesmas mostraram-se extremamente altas, comparadas às do trabalho de Thame et al. (1987), para os anos de 1970, 1980 e para o conjunto 1970-1980. Dessa forma, conclui-se que a variável capital apresentou-se muito favorável ao aumento dos salários dos trabalhadores rurais do Paraná.

No que se refere a relação área trabalhador, como foi destacado anteriormente, a mesma indica, a grosso modo, o grau de inovações mecânicas em cada MRH do estado. A análise descritiva indicou um maior valor relativo desta variável para aquelas MRH onde havia uma maior quantidade dos cultivos de culturas modernas, mais intensivas em capital, confirmando nossa expectativa inicial. No que diz respeito a sua evolução, verificou-se aumento principalmente para as MRH onde houve a substituição de culturas tradicionais pelas modernas. Em contrapartida, percebeu-se uma diminuição dessa razão para a maioria das MRH onde permaneceram culturas mais intensivas em mão-de-obra.

Este resultado foi confirmado pelo modelo econométrico adotado, através dos coeficientes de elasticidade, que apresentaram significativa participação nas mudanças dos salários dos trabalhadores rurais. Assim, esta variável permitiu concluir que a relação área trabalhador contribuiu de maneira substancial para o aumento do nivel de inovações mecànicas no setor rural, aumentando os salários dos trabalhadores deste setor.

Finalmente, pode-se destacar que os instrumentais utilizados mostraram-se satisfatórios para mensurar o grau de contribuição da educação formal nos rendimentos dos trabalhadores rurais, nos anos de 1970 e 1980 e no conjunto 1970-1980, no Estado do Paraná. Permitiram confirmar não só os resultados apresentados nos estudos anteriores, como também a importância da educação como determinante dos salários também no setor agricola. Por fim, o trabalho modestamente sugere políticas educacionais que promovam uma melhor qualificação técnica, permitindo ao trabalhador, além de melhores rendimentos, uma combinação mais eficientemente dos fatores de produção, bem como seu domicílio permanente no setor agrícola. 
ANEXO 
Anexo A Máquinas e equipamentos agricolas, variações percentuais, por microrregiões homogêneas do Paraná. 1970 - 1980.

\begin{tabular}{|c|c|c|c|c|c|c|c|c|c|}
\hline \multirow[b]{3}{*}{ MRH } & \multicolumn{3}{|c|}{ Tratores acima de $50 \mathrm{CV}$} & \multicolumn{3}{|c|}{ Colhedeiras } & \multicolumn{3}{|c|}{ Arados de tração mecânica } \\
\hline & \multicolumn{2}{|c|}{ Quantidades } & \multirow[b]{2}{*}{$\Delta \%$} & \multicolumn{2}{|c|}{ Quantidades } & \multirow[b]{2}{*}{$\Delta \%$} & \multicolumn{2}{|c|}{ Quantidades } & \multirow[b]{2}{*}{$\Delta \%$} \\
\hline & 1970 & 1980 & & 1970 & 1980 & & 1970 & 1980 & \\
\hline 268 & 117 & 1.175 & 904.3 & 145 & 273 & 88.3 & 408 & 1.815 & 344.9 \\
\hline 269 & 7 & 95 & 1.257 .1 & 13 & 6 & -53.8 & 59 & 298 & 405,1 \\
\hline 270 & 1 & 61 & 6.000 .0 & 9 & 1 & -88.9 & 9 & 59 & 555.6 \\
\hline 271 & 3 & $1+3$ & +666.7 & 172 & 26 & -84.9 & 15 & 257 & 1.613 .3 \\
\hline 272 & 84 & 1.153 & 1.272 .6 & 107 & 362 & 238.3 & 270 & 1.174 & 334.8 \\
\hline 271 & 404 & 2.395 & +92.8 & 317 & 766 & $1+1.6$ & 932 & $2 .+57$ & 163.6 \\
\hline 274 & 119 & 626 & +26.1 & 73 & 203 & 178.1 & 157 & 618 & 293.6 \\
\hline 275 & 11 & 358 & 3.154 .5 & 11 & 88 & 700.0 & 32 & 359 & 1.021 .9 \\
\hline 276 & 79 & 1.131 & 1.331 .6 & 118 & 385 & 226.3 & 108 & 1.265 & 1.071 .3 \\
\hline 277 & 42 & 797 & 1.797 .6 & 32 & 282 & 781,3 & 97 & 923 & 851.5 \\
\hline 278 & 105 & 1.251 & 1.091 .4 & 327 & 309 & -5.5 & 391 & 1.795 & 359.1 \\
\hline 279 & 1.119 & 4.588 & 310.0 & 782 & 1.095 & 40.0 & 3.344 & 6.919 & 106.9 \\
\hline 280 & 321 & 1.841 & 473.5 & 506 & 534 & 5,5 & 2.154 & +.126 & 91.6 \\
\hline 281 & 1.002 & 6.181 & 516.9 & 872 & 1.550 & 77.8 & 3.535 & 9.959 & 181.7 \\
\hline 282 & $4+3$ & 3.531 & 697.1 & 553 & 994 & 79,7 & 1.114 & +.920 & 341.7 \\
\hline 283 & 249 & 2.151 & 763.9 & 153 & 228 & 49.0 & 621 & 3.919 & 531.1 \\
\hline 284 & 273 & 3.325 & 1.117 .9 & 859 & 1.885 & 119.4 & 815 & +.661 & $+71,9$ \\
\hline 285 & 272 & 2.564 & 842.6 & 265 & 594 & 124.2 & 690 & 3.525 & $+10,9$ \\
\hline 286 & 640 & 6.932 & 983.1 & 788 & 2.593 & 229.1 & 1.434 & 8.603 & 499.9 \\
\hline 287 & 45 & 897 & 1.893 .3 & 246 & 690 & 180.5 & 85 & 1.066 & $1.154,1$ \\
\hline 288 & 719 & 14.271 & 1.884 .8 & 8.199 & 9.064 & 10.6 & 1.485 & 21.761 & 1.365 .4 \\
\hline 289 & 130 & 4.975 & 3.726 .9 & 4.259 & 4.194 & -1.5 & 337 & 6.488 & 1.825 .2 \\
\hline 290 & 405 & 2.324 & 473,8 & 470 & 1.430 & 204,3 & 652 & 2.239 & 243,4 \\
\hline 291 & 67 & 1.021 & 1.423 .9 & 443 & 491 & 10,8 & 139 & 1.320 & 849.6 \\
\hline Total & 6.657 & 63.786 & 858.2 & 19.719 & 28.043 & 42.2 & 18.883 & 90.526 & 379.4 \\
\hline
\end{tabular}

Fonte: FIBGE - Censos Agropecuário do Paraná 1970-1980. 
Anexo B.1 Áreas plantadas e participação (\%) das culturas temporárias e permanentes por microrregiões homogèneas do Paraná. nos anos de 1970 e 1980.

\begin{tabular}{|c|c|c|c|c|c|c|c|c|}
\hline \multirow[b]{2}{*}{ Culturas } & \multicolumn{4}{|c|}{268 - Curitiba } & \multicolumn{4}{|c|}{269 - Litoral Paranaense } \\
\hline & 1970 & part ${ }^{\circ}$ & 1980 & part. $\%$ & 1970 & part. ${ }_{0}^{\circ}$ & 1980 & part $\%$ \\
\hline Algodão & 0 & 0.00 & 0 & 0.00 & 0 & 0,00 & 0 & 0.00 \\
\hline Amendoim & 11 & 0.01 & 100 & 0.12 & 0 & 0,00 & 2 & 0.04 \\
\hline ArToz & 1.128 & 1.09 & 1.282 & 1.53 & 1.766 & 37,97 & 1.642 & 30.67 \\
\hline Batata Inglesa & 10.004 & 9.66 & 9.781 & 11,64 & 1 & 0.02 & 0 & 0,00 \\
\hline Cana-de-açuear & 17 & 0.02 & 18 & 0.02 & 245 & 5,27 & 398 & 7,44 \\
\hline Feijão & 26.209 & 25.30 & 23.746 & 28.26 & 99 & 2,13 & 491 & 9,17 \\
\hline Mandioa & 115 & 0.11 & 158 & 0,19 & 1.274 & 27.39 & 1.112 & 20.77 \\
\hline Milho & 59.556 & 57.49 & +6.809 & 55.70 & 1.198 & 25.76 & 1.324 & 24.73 \\
\hline Trigo & 5.617 & 5.42 & 353 & 0.42 & 0 & 0.00 & 0 & 0.00 \\
\hline Soja & 98 & 0.09 & 1.373 & 1.63 & 0 & 0.00 & 0 & 0.00 \\
\hline Cafè & 0 & 0.00 & 0 & 0,00 & 41 & 0,88 & 149 & 2,78 \\
\hline Laranja & 114 & 0.11 & 58 & 0,07 & 27 & 0.58 & 235 & 4,39 \\
\hline Uva & 720 & 0,70 & 353 & 0.42 & 0 & 0,00 & 0 & 0,00 \\
\hline Total & 103.589 & 100.00 & 84.031 & 100,00 & 4.651 & 100.00 & 5.353 & 100.00 \\
\hline
\end{tabular}

Fonte: FIBGE - Censos Agropecuário do Paraná 1970-1980.

Anexo B.2 Áreas plantadas e participação (\%) das culturas temporárias e permanentes por microrregiões homogèneas do Paraná. nos anos de 1970 e 1980.

\begin{tabular}{|c|c|c|c|c|c|c|c|c|}
\hline \multirow[b]{2}{*}{ Culturas } & \multicolumn{4}{|c|}{270 - Alto Ribeira } & \multicolumn{4}{|c|}{271 - Alto Rio Negro Paranaense } \\
\hline & 1970 & part. ${ }_{0}$ & 1980 & part $0_{0}$ & 1970 & part. $\%$ & 1980 & part. $\%$ \\
\hline Algodāo & 0 & 0.00 & 0 & 0.00 & 0 & 0,00 & 0 & 0.00 \\
\hline Amendoim & 16 & 0.06 & 14 & 0.06 & 3 & 0.01 & 10 & 0,04 \\
\hline Arroz & 334 & 1.31 & 703 & 2.97 & 92 & 0,30 & 228 & 0,92 \\
\hline Batata Inglesa & 3 & 0.01 & 0 & 0,00 & 840 & 2.77 & 1.468 & 5.94 \\
\hline Cana-de-açuicar & 96 & 0.38 & 19 & 0,08 & 0 & 0.00 & 0 & 0.00 \\
\hline Feijāo & 7.528 & 29.43 & 9.021 & 38,05 & 6.769 & 22,32 & 7.247 & 29.33 \\
\hline Mandioca & 142 & 0,56 & 54 & 0,23 & 57 & 0.19 & 25 & 0,10 \\
\hline Milho & 16.924 & 66.17 & 12.962 & 54,67 & 19.495 & 64,29 & 15.532 & 62,85 \\
\hline Trigo & 0 & 0.00 & 0 & 0,00 & 3.005 & 9,91 & 133 & 0,54 \\
\hline Soja & 0 & 0,00 & 26 & 0,11 & 50 & 0,16 & 64 & 0,26 \\
\hline Café & 14 & 0.05 & 8 & 0.03 & 0 & 0.00 & 0 & 0,00 \\
\hline Laranja & 516 & 2.02 & 894 & 3,77 & 4 & 0.01 & 2 & 0,01 \\
\hline Uva & 5 & 0,02 & 8 & 0,03 & 10 & 0.03 & 2 & 0,01 \\
\hline Total & 25.578 & 100.00 & 23.709 & 100,00 & 30.325 & 100.00 & 24.711 & 100,00 \\
\hline
\end{tabular}

Fonte: FIBGE - Censos Agropecuário do Paraná 1970-1980. 
Anexo B.3 Áreas plantadas e participação (\%) das culturas temporárias e permanentes por microrregiões homogèneas do Paraná, nos anos de 1970 e 1980.

\begin{tabular}{|c|c|c|c|c|c|c|c|c|}
\hline \multirow[b]{2}{*}{ Cutturas } & \multicolumn{4}{|c|}{272 - Campos da Lapa } & \multicolumn{4}{|c|}{273 - Campos de Ponta Grossa } \\
\hline & 1970 & part. $\%$ & 1980 & part $\%$ & 1970 & part. $\%$ & 1980 & part. ${ }^{\circ}$ \\
\hline Algodão & 0 & 0.00 & 0 & 0,00 & 0 & 0,00 & 0 & 0,00 \\
\hline Amendoim & 44 & 0.08 & 132 & 0.17 & 30 & 0.03 & 56 & 0,03 \\
\hline Arroz & 1.793 & 3.21 & 4.391 & 5,73 & 10808 & 12.52 & 8091 & 4.13 \\
\hline Batata Inglesa & 2.465 & 4.42 & 3.714 & 4.84 & 2.931 & 3,40 & 2.324 & 1,19 \\
\hline Cana-de-açucar & 6 & 0,01 & 0 & 0,00 & 47 & 0,05 & 905 & 0,46 \\
\hline Feijão & 17.771 & 31.84 & 15.572 & 20,31 & 15.516 & 17,97 & 17.557 & 8.96 \\
\hline Mandioca & 321 & 0.58 & 149 & 0.19 & 1.013 & 1.17 & 238 & 0.12 \\
\hline Mitho & 27.165 & 48.67 & 27.863 & 36.35 & 32.992 & 38.22 & 42.562 & 21.72 \\
\hline Trigo & 5.643 & 10.11 & 5.540 & 7.23 & 16.453 & 19.06 & 35.280 & 18.01 \\
\hline Soja & 568 & 1.02 & 19.227 & 25.08 & 6.410 & 7.43 & 88.824 & 45.33 \\
\hline Cafè & 0 & 0.00 & 0 & 0.00 & 2 & 0.00 & 2 & 0.00 \\
\hline Laranja & 27 & 0.05 & 56 & 0,07 & 36 & 0,04 & 39 & 0,02 \\
\hline tva & 16 & 0.03 & 17 & 0.02 & 87 & 0.10 & 53 & 0.03 \\
\hline Toxal & 55.819 & 100,00 & $76.66 \mathrm{I}$ & 100,00 & 86.325 & 100,00 & 195.931 & 100,00 \\
\hline
\end{tabular}

Fonte: FIBGE - Censos Agropecuário do Paraná 1970-1980.

Anexo B.4 Áreas plantadas e participação (\%) das culturas temporárias e permanentes por microrregiões homogêneas do Paraná, nos anos de 1970 e 1980.

\begin{tabular}{|c|c|c|c|c|c|c|c|c|}
\hline \multirow[b]{2}{*}{ Culturas } & \multicolumn{4}{|c|}{274 - Campos de Jaguariaiva } & \multicolumn{4}{|c|}{275 - São Mateus do Sul } \\
\hline & 1970 & part. \% & 1980 & part. $\%$ & 1970 & part. \% & 1980 & part. ${ }^{\circ} o$ \\
\hline Algodão & 0 & 0,00 & 29 & 0,04 & 0 & 0.00 & 0 & 0,00 \\
\hline Amendoim & 2 & 0.01 & 12 & 0,02 & 15 & 0,04 & 22 & 0.05 \\
\hline Arroz & 3.788 & 10,29 & 3.983 & 5,61 & 2.188 & 6,08 & 2.113 & 4,36 \\
\hline Batata Inglesa & 41 & 0.11 & 2 & 0,00 & 121 & 0,34 & 794 & 1.64 \\
\hline Cana-de-açucar & 1 & 0.00 & 8 & 0,01 & 0 & 0,00 & 0 & 0,00 \\
\hline Feijão & 8.615 & 23.41 & 19.130 & 26,93 & 13.807 & 38,37 & 17.639 & 36.38 \\
\hline Mandioca & 16 & 0.04 & 83 & 0,12 & 129 & 0,36 & 95 & 0.20 \\
\hline Nitho & 22.063 & 59.96 & 24.188 & 34,05 & 18.607 & 51,70 & 21.536 & 44.42 \\
\hline Trigo & 1.312 & 3.57 & 10.140 & 14,27 & 1.105 & 3,07 & 1.283 & 2,65 \\
\hline Soja & 738 & 2.01 & 13.214 & 18,60 & 9 & 0,03 & 4.994 & 10,30 \\
\hline Café & 211 & 0.57 & 220 & 0,31 & 0 & 0,00 & 0 & 0,00 \\
\hline Laranja & 8 & 0.02 & 30 & 0,04 & 7 & 0,02 & 3 & 0.01 \\
\hline lva & 0 & 0.00 & 0 & 0,00 & 0 & 0,00 & 2 & 0,00 \\
\hline Toal & 36.795 & 100.00 & 71.039 & 100,00 & 35.988 & 100.00 & 48.481 & 100,00 \\
\hline
\end{tabular}

Fonte: FIBGE - Censos Agropecuário do Paraná 1970-1980. 
Anexo B.5 Áreas plantadas e participação (\%) das culturas temporárias e permanentes por microrregiões homogêneas do Paraná, nos anos de 1970 e 1980

\begin{tabular}{|c|c|c|c|c|c|c|c|c|}
\hline \multirow[b]{2}{*}{ Culturas } & \multicolumn{4}{|c|}{276 - Colonial do Irati } & \multicolumn{4}{|c|}{277 - Alto Ivaí } \\
\hline & 1970 & part. $\%_{0}^{\circ}$ & 1980 & part $\%$ & 1970 & part. $\%$ & 1980 & part. $\%$ \\
\hline Hgodão & 0 & 0.00 & 0 & 0,00 & 7 & 0,01 & 388 & 0.23 \\
\hline Amendoim & 62 & 0.04 & 100 & 0,05 & 29 & 0.02 & 125 & 0,08 \\
\hline Arroz & 6.960 & 4.66 & 8.294 & 4.40 & 9.686 & 7.74 & 7.165 & 4,32 \\
\hline Batata Inglesa & 4.771 & 3,20 & 1.917 & 1,02 & 605 & 0,48 & 105 & 0,06 \\
\hline Cana-de-açucar & 19 & 0.01 & 15 & 0.01 & 32 & 0.03 & 27 & 0,02 \\
\hline Feijão & 49.027 & 32.83 & 66.942 & 35,49 & 35.796 & 28.59 & 37.892 & 22,83 \\
\hline Mandioca & 767 & 0.51 & 249 & 0.13 & 577 & 0.46 & 213 & 0.13 \\
\hline Milho & 79.435 & $\$ 3.20$ & 87.677 & 46.49 & 76.741 & 61,29 & 91.035 & 54.84 \\
\hline Trigo & 7.713 & 5.17 & 2.801 & 1.49 & 1.566 & 1.25 & 9.133 & 5.50 \\
\hline Soja & 376 & 0.25 & 20.511 & 10,88 & 121 & 0.10 & 19.711 & 11.87 \\
\hline Cafë & 0 & 0.00 & 0 & 0.00 & 35 & 0.03 & 146 & 0.09 \\
\hline Laranja & 67 & 0,04 & 43 & 0,02 & 9 & 0,01 & 53 & 0,03 \\
\hline Uva & 121 & 0.08 & 54 & 0,03 & 11 & 0.01 & 8 & 0,00 \\
\hline Total & 149.318 & 100,00 & 188.603 & 100,00 & 125.215 & 100,00 & 166.001 & 100,00 \\
\hline
\end{tabular}

Fonte: FIBGE - Censos Agropecuário do Paraná 1970-1980

Anexo B.6 Áreas plantadas e participação (\%) das culturas temporárias e permanentes por microrregiões homogêneas do Paraná, nos anos de 1970 e 1980.

\begin{tabular}{|c|c|c|c|c|c|c|c|c|}
\hline \multirow[b]{2}{*}{ Culturas } & \multicolumn{4}{|c|}{278 - Norte Velho Venceslau Bráz } & \multicolumn{4}{|c|}{279 - Norte Velho de Jacarezinho } \\
\hline & 1970 & part. $\%$ & 1980 & part. \% & 1970 & part. ${ }^{\circ}$ & 1980 & part. $\%$ \\
\hline Algodão & 31 & 0,02 & 581 & 0,29 & 33.583 & 8,13 & 44.358 & 11,87 \\
\hline Amendoim & 41 & 0.02 & 129 & 0,07 & 3.705 & 0,90 & 183 & 0,05 \\
\hline Arroz & 21.366 & 11,66 & 14.535 & 7.36 & 20.384 & 4.93 & 7.057 & 1,89 \\
\hline Batata Inglesa & 1.207 & 0,66 & 388 & 0,20 & 40 & 0.01 & 0 & 0,00 \\
\hline Cana-de-açucar & 91 & 0,05 & 1.735 & 0,88 & 11.357 & 2.75 & 25.534 & 6,83 \\
\hline Feijão & 59.772 & 32.62 & 79.188 & 40,12 & 102.451 & 24.79 & 12.358 & 3,31 \\
\hline Mandioca & 290 & 0,16 & 424 & 0.21 & 190 & 0,05 & 116 & 0,03 \\
\hline Milho & 75.915 & 41,43 & 73.885 & 37,44 & 135.732 & 32,84 & 65.874 & 17,63 \\
\hline Trigo & 12 & 0,01 & 229 & 0,12 & 16.717 & 4,04 & 80.892 & 21,65 \\
\hline Soja & 13 & 0.01 & 480 & 0.24 & 10.417 & 2.52 & 97.973 & 26,22 \\
\hline Café & 24.360 & 13,29 & 25.609 & 12,98 & 78.517 & 19,00 & 39.159 & 10,48 \\
\hline Laranja & 102 & 0.06 & 163 & 0,08 & 169 & 0,04 & 125 & 0,03 \\
\hline Uva & 37 & 0,02 & 8 & 0,00 & 55 & 0,01 & 40 & 0,01 \\
\hline Total & 183.237 & 100.00 & 197.354 & 100,00 & 413.317 & 100,00 & 373.669 & 100,00 \\
\hline
\end{tabular}

Fonte: FIBGE - Censos Agropecuário do Paraná 1970-1980. 
Anexo B.7 Áreas plantadas e participação (\%) das culturas temporárias e permanentes por microrregiōes homogêneas do Paraná, nos anos de 1970 e 1980

\begin{tabular}{|c|c|c|c|c|c|c|c|c|}
\hline \multirow[b]{2}{*}{ Cuhuras } & \multicolumn{4}{|c|}{280 - Algodoeira de Assaí } & \multicolumn{4}{|c|}{281 - Norte Novo de Londrina } \\
\hline & 1970 & part. ${ }^{\circ}$ & 1980 & part. \% & 1970 & part. $\%$ & 1980 & part. ${ }^{\circ}$ \\
\hline Algodão & 37.820 & 33.35 & 31.617 & 26,02 & 55.037 & 14.26 & 23.839 & 5.05 \\
\hline Amendoim & 1.851 & 1.63 & 98 & 0,08 & 11.446 & 2,97 & 4.215 & 0,89 \\
\hline Arroz & 10.408 & 9.18 & 2.367 & 1.95 & 50.412 & 13.06 & 10.008 & 2.12 \\
\hline Batata Inglesa & 14 & 0.01 & 0 & 0,00 & 46 & 0.01 & 0 & 0,00 \\
\hline Cana-de-açùcar & 76 & 0.07 & 82 & 0.07 & 13.368 & 3.46 & 22.507 & 4,77 \\
\hline Feijão & 18.690 & 16,48 & 7.905 & 6.51 & 20.248 & 5,25 & 8.654 & 1,83 \\
\hline Mlandioca & 16 & 0.01 & 2 & 0.00 & 543 & 0.14 & 353 & 0,07 \\
\hline Milho & 30.424 & 26,83 & 13.112 & 10.79 & 95.554 & 24.76 & 81.554 & 17.28 \\
\hline Trigo & 6.170 & 5.44 & 28.302 & 23.29 & 11.316 & 2.93 & 79.907 & 16.93 \\
\hline Soja & 2.918 & 2,57 & 32.952 & 27,12 & 10.960 & 2,84 & 128.970 & 27,33 \\
\hline Cafế & 4.777 & 4.21 & 4.925 & 4.05 & 116.265 & 30.13 & 111.679 & 23.66 \\
\hline Laranja & 24 & 0,02 & 11 & 0,01 & 463 & 0,12 & 121 & 0,03 \\
\hline Lva & 210 & 0.19 & 144 & 0.12 & 208 & 0,05 & 117 & 0,02 \\
\hline Total & 113.398 & 100,00 & 121.517 & 100,00 & 385.866 & 100,00 & 471.924 & 100,00 \\
\hline
\end{tabular}

Fonte: FIBGE - Censos Agropecuário do Paraná 1970-1980.

Anexo B.8 Áreas plantadas e participação (\%) das culturas temporárias e permanentes por microrregiões homogêneas do Paraná, nos anos de 1970 e 1980

\begin{tabular}{|c|c|c|c|c|c|c|c|c|}
\hline \multirow[b]{2}{*}{ Culturas } & \multicolumn{4}{|c|}{282 - Norte Novo de Maringá } & \multicolumn{4}{|c|}{283 - Norte Novíssimo de Paranavaí } \\
\hline & 1970 & part. ${ }_{0}^{\circ}$ & 1980 & part. $\%$ & 1970 & part. $\%$ & 1980 & part. ${ }^{\circ}$ \\
\hline Algodão & 13.989 & 8.34 & 6.150 & 2,12 & 36.440 & 4.40 & 6.183 & 3.68 \\
\hline Amendoim & 5.920 & 3.53 & 1.211 & 0.42 & 11.209 & 1.84 & 2.589 & 1,54 \\
\hline Arroz & 22.150 & 13,21 & 3.556 & 1,22 & 13.625 & 4.89 & 6.871 & 4,09 \\
\hline Batata Inglesa & 45 & 0,03 & 0 & 0,00 & 7 & 0.00 & 0 & 0.00 \\
\hline Cana-de-açucar & 1.480 & 0.88 & 4.574 & 1.58 & 240 & 1.01 & 1.426 & 0.85 \\
\hline Feijão & 7.371 & 4.40 & 4.224 & 1,46 & 9.734 & 6,16 & 8.658 & 5,15 \\
\hline Mandioca & 191 & 0.11 & 196 & 0,07 & 2.835 & 1,86 & 2.611 & 1.55 \\
\hline Wilho & 53.806 & 32.09 & 23.304 & 8.03 & 41.593 & 17,38 & 24.422 & 14,53 \\
\hline Trigo & 8.458 & 5.04 & 82.647 & 28,47 & 817 & 3,05 & 4.291 & 2,55 \\
\hline Soja & 49.095 & 29.28 & 125.893 & 43,37 & 3.791 & 5.47 & 7.684 & 4,57 \\
\hline Cafè & 4.871 & 2,91 & 38.399 & 13,23 & 20.097 & 73.49 & 103.265 & 61.42 \\
\hline Laranja & 131 & 0,08 & 48 & 0,02 & 94 & 0.07 & 100 & 0,06 \\
\hline Uva & 165 & 0,10 & 100 & 0,03 & 32 & 0.02 & 25 & 0,01 \\
\hline Total & 167.672 & 100.00 & 290.302 & 100,00 & 140.514 & 119,65 & 168.125 & 100,00 \\
\hline
\end{tabular}

Fonte: FIBGE - Censos Agropecuário do Paraná 1970-1980. 
Anexo B.9 Áreas plantadas e participação (\%) das culturas temporárias e permanentes por microrregiões homogêneas do Paraná, nos anos de 1970 e 1980.

\begin{tabular}{|c|c|c|c|c|c|c|c|c|}
\hline \multirow[b]{2}{*}{ Culturas } & \multicolumn{4}{|c|}{ 284- Norte Novo de Apucarana } & \multicolumn{4}{|c|}{285 - Norte Novissimo de Umuarama } \\
\hline & 1970 & pan. $\%$ & 1980 & part $\%$ & 1970 & part. $\%$ & 1980 & part. $\%$ \\
\hline Algodào & 6.382 & 1.42 & 29.669 & 7.26 & 92.414 & 21,84 & 31.910 & 8.18 \\
\hline Amendoim & 532 & 0,12 & 837 & 0.20 & 49.621 & 11,73 & 10.767 & 2.76 \\
\hline Arroz & 64.467 & 14.30 & 16.473 & 4.03 & 38.201 & 9.03 & 18.844 & 4.83 \\
\hline Batata Inglesa & 76 & 0,02 & 5 & 0.00 & 76 & 0,02 & 1 & 0.00 \\
\hline Cana-de-açicar & 153 & 0,03 & 268 & 0.07 & 228 & 0.05 & 710 & 0.18 \\
\hline Feijão & 139.297 & 30,90 & 98.249 & 24.03 & 54.726 & 12.93 & 41.596 & 10,66 \\
\hline Mandioca & 331 & 0.07 & 369 & 0.09 & 3.223 & 0.76 & 3.331 & 0,85 \\
\hline Milho & 189.013 & 41.92 & 124.028 & 30.33 & 101.800 & 24.06 & 51.733 & 13,26 \\
\hline Trigo & 5.353 & 1.19 & 34.976 & 8.55 & 3.640 & 0.86 & 20.437 & 5.24 \\
\hline Soja & 5.847 & 1.30 & 61.655 & 15.08 & 39.353 & 9.30 & 33.476 & 8.58 \\
\hline Cafè & 39.140 & 8.68 & 42.038 & 10.28 & 39.482 & 9,33 & 177.012 & 45,38 \\
\hline Laranja & 206 & 0,05 & 274 & 0,07 & 321 & 0,08 & 228 & 0,06 \\
\hline Uva & 66 & 0.01 & 27 & 0.01 & 35 & 0,01 & 28 & 0,01 \\
\hline Total & 450.863 & 100,00 & 408.868 & 100,00 & 423.120 & 100,00 & 390.073 & 100,00 \\
\hline
\end{tabular}

Fonte: FIBGE - Censos Agropecuário do Paraná 1970-1980.

Anexo B.10 Áreas plantadas e participação (\%) das culturas temporárias e permanentes por microrregiões homogêneas do Paraná, nos anos de 1970 e 1980.

\begin{tabular}{|c|c|c|c|c|c|c|c|c|}
\hline \multirow[b]{2}{*}{ Culturas } & \multicolumn{4}{|c|}{286 - Campo Mourão } & \multicolumn{4}{|c|}{287 - Pitanga } \\
\hline & 1970 & part. $\%$ & 1980 & part. $\%$ & 1970 & part. ${ }^{\circ}$ & 1980 & part. \% \\
\hline Algodão & 84.216 & 16,40 & 61.801 & 8,37 & 731 & 0,55 & 3.857 & 1,94 \\
\hline Amendoim & 19.816 & 3,86 & 4.144 & 0.56 & 45 & 0,03 & 151 & 0,08 \\
\hline Arroz & 65.661 & 12,79 & 17.338 & 2,35 & 7.005 & 5,31 & 9.343 & 4.69 \\
\hline Batata Inglesa & 65 & 0,01 & 0 & 0,00 & 160 & 0,12 & 17 & 0,01 \\
\hline Cana-de-açuicar & 341 & 0.07 & 2.312 & 0,31 & 84 & 0,06 & 15 & 0,01 \\
\hline Feijão & 83.196 & 16,20 & 37.983 & 5,15 & 29.659 & 22.46 & 39.745 & 19,96 \\
\hline Mandioca & 2.691 & 0,52 & 1.273 & 0,17 & 736 & 0,56 & 768 & 0.39 \\
\hline Milho & 168.331 & 32.78 & 100.371 & 13.60 & 88.749 & 67.21 & 120.813 & 60,69 \\
\hline Trigo & 16.758 & 3,26 & 158.330 & 21,45 & 3.986 & 3,02 & 4.779 & 2,40 \\
\hline Soja & 46.296 & 9.01 & 314.434 & 42,61 & 679 & 0.51 & 19.230 & 9,66 \\
\hline Café & 25.938 & 5,05 & 39.733 & 5,38 & 148 & 0.11 & 345 & 0.17 \\
\hline Laranja & 218 & 0,04 & 256 & 0,03 & 49 & 0,04 & 10 & 0,01 \\
\hline Uva & 23 & 0,00 & 9 & 0,00 & 7 & 0,01 & 7 & 0,00 \\
\hline Total & 513.550 & 100.00 & 737.984 & 100.00 & 132.038 & 100,00 & 199.080 & 100,00 \\
\hline
\end{tabular}

Fonte: FIBGE - Censos Agropecuário do Paraná 1970-1980. 
Anexo B.11 Áreas plantadas e participação (\%) das culturas temporárias e permanentes por microrregiões homogêneas do Paraná, nos anos de 1970 e 1980.

\begin{tabular}{|c|c|c|c|c|c|c|c|c|}
\hline \multirow[b]{2}{*}{ Culturas } & \multicolumn{4}{|c|}{288 - Extremo Oeste Paranaense } & \multicolumn{4}{|c|}{ 289- Sudoeste Paranacnse } \\
\hline & 1970 & part $?_{0}$ & 1980 & part $\%$ & 1970 & part. .9 & 1980 & part. \% \\
\hline Algodĩo & 12.635 & 1,57 & 23.335 & 1,39 & 0 & 0,00 & 7 & 0,00 \\
\hline Amendoim & 4.693 & 0.58 & 2.303 & 0,14 & 824 & 0.17 & 1.254 & 0.17 \\
\hline Arroz & 43.680 & 5,42 & 27.874 & 1.66 & 20.469 & 4,15 & 19.958 & 2,72 \\
\hline Batata Inglesa & 421 & 0,05 & 17 & 0,00 & 1.099 & 0,22 & 177 & 0.02 \\
\hline Cana-de-açucar & 581 & 0,07 & 737 & 0,04 & 1.476 & 0,30 & 1.410 & 0,19 \\
\hline Feijāo & 108.828 & 13,50 & 61.203 & 3,64 & 74.932 & 15.20 & 97.092 & 13.24 \\
\hline Siandioca & 38.605 & 4,79 & 17.655 & 1.05 & 27.896 & 5.66 & 14.201 & 1.94 \\
\hline Mitho & 395.583 & 49.07 & 266.776 & 15.88 & 246.665 & 50.04 & 345.073 & 47,06 \\
\hline Trigo & 41.555 & 5.15 & 496.857 & 29.57 & 57.920 & 11.75 & 47.432 & 6.47 \\
\hline Soja & 151.494 & 18.79 & 747.737 & 44.50 & 60.345 & 12.24 & 204.871 & 27.94 \\
\hline Cafè & 6.999 & 0.87 & 34.589 & 2.06 & 2 & 0.00 & 35 & 0.00 \\
\hline Laranja & 770 & 0,10 & 1.089 & 0,06 & 857 & 0.17 & 1.287 & 0,18 \\
\hline Uva & 297 & 0.04 & 294 & 0,02 & 419 & 0.09 & 399 & 0,05 \\
\hline Total & 806.141 & 100,00 & 1.680 .466 & 100,00 & 492.904 & 100,00 & 733.196 & 100.00 \\
\hline
\end{tabular}

Fonte: FIBGE - Censos Agropecuário do Paraná 1970-1980.

Anexo B.12 Áreas plantadas e participação (\%) das culturas temporárias e permanentes por microrregiões homogêneas do Paraná, nos anos de 1970 e 1980.

\begin{tabular}{|c|c|c|c|c|c|c|c|c|}
\hline \multirow[b]{2}{*}{ Culturas } & \multicolumn{4}{|c|}{290 - Campos de Guarapuava } & \multicolumn{4}{|c|}{291 - Médio Iguaçu } \\
\hline & 1970 & part $\%$ & 1980 & part. \% & 1970 & part. ${ }^{\circ}$ & 1980 & part. ${ }^{\circ} \circ$ \\
\hline Algodão & 0 & 0,00 & 0 & 0,00 & 0 & 0,00 & 0 & 0.00 \\
\hline tmendoim & 94 & 0,05 & 228 & 0.07 & 159 & 0.21 & 168 & 0.14 \\
\hline Arroz & 16.376 & 9,17 & 14.199 & 4,35 & 8.899 & 11,78 & 9.760 & 8,17 \\
\hline Batata Inglesa & 598 & 0.33 & 1.508 & 0.46 & 297 & 0.39 & 193 & 0.16 \\
\hline Cana-de-açucar & 61 & 0,03 & 29 & 0.01 & 37 & 0,05 & 14 & 0.01 \\
\hline Feijão & 25.327 & 14,19 & 36.931 & 11.32 & 11.606 & 15.36 & 15.379 & 12.88 \\
\hline Mandioca & 1.579 & 0,88 & 738 & 0.23 & 3.908 & 5.17 & 2.301 & 1,93 \\
\hline Milho & 99.128 & 55.52 & 153.413 & 47,01 & 44.738 & 59.21 & 46.813 & 39.20 \\
\hline Trigo & 29.934 & 16,77 & 27.723 & 8,49 & 5.165 & 6.84 & 3.886 & 3.25 \\
\hline Soja & 5.359 & 3,00 & 91.527 & 28,05 & 548 & 0,73 & 40.760 & 34,14 \\
\hline Cafế & 0 & 0,00 & 0 & 0.00 & 0 & 0,00 & 0 & 0,00 \\
\hline Laranja & 34 & 0.02 & 38 & 0,01 & 60 & 0,08 & 42 & 0,04 \\
\hline Uva & 49 & 0,03 & 12 & 0,00 & 136 & 0,18 & 90 & 0,08 \\
\hline Total & 178.539 & 100,00 & 326.346 & 100,00 & 75.553 & 100.00 & 119.406 & 100,00 \\
\hline
\end{tabular}

Fonte: FIBGE - Censos Agropecuário do Paraná 1970-1980. 


\section{REFERÊNCIAS BIBLIOGRÁFICAS}

ALVES, E. Migração rural-urbana. Revista de Política Agrícola, v. 4, p.15-29, out./dez. 1995.

ANDRADE, M. P. Estrutura fundiária, modernização e distribuição da renda na agricultura mato-grossense. Piracicaba: 1989. 201p. Dissertação (Mestrado) Escola Superior de Agricultura "Luiz de Queiroz", Universidade de São Paulo.

ANUÁRIO ESTATÍSTICO DO BRASIL. Rio de Janeiro: FIBGE, 1994

ARAÚJO, P. F. C. de. O sistema de relações econômicas na agricultura. Piracicaba: ESALQ, 1996. p.42-68 (notas de aula mimeo).

ARAÚJO, P. F. C. de; TOSCANO, G.; SHIROTA, R.; BURNQUIST, H. L.; YAMAGUISHI, C. T. Desempenho do mercado de trabalho na agricultura. Piracicaba: Fundação de Estudos Agrários "Luiz de Queiróz" - FEALQ, 1985 (Relatório de pesquisa).

ASSUMPÇÃO, A. G. de; GALINA, L. A.; CONSONI, R. Mudanças no padrão de desenvolvimento agro-industrial: o caso do norte do Paraná. Revista de Economia e Sociologia Rural, v. 28, n.4, p.132-142, out./dez.1990.

BARROS, R. P. de; MENDONÇA, R. S. P. de. Os determinantes da desigualdade no Brasil. Texto para discussão, IPEA, n. 377, jul. 1995. 
BECKER. G. S. Human capital: A theoretical and empirical analysis, with special reference to education. 3. ed. Chicago: editores, 1993. p.15-131.

BLACK. R. Migration. Return, and Agricultural development in the Serra do Alvão, Northern Portugal: Economic development and Cultural Change, v. 41 , n. 3 , p.563-583, Apr. 1993.

CASTRO. A. B. de. 7 ensaios sobre a economia brasileira. 3. ed. Rio de Janeiro: Forense Universitária, 1972. 193p

CLNHA. A. S., MAIA, M. M. Modernização tecnológica e emprego rural: evidencias da década de 70 na regiào centro-sul do Brasil. Conferencia Latinoamericana de Economia Agrícola, Piracicaba: ESALQ, 1984.

DEL GROSSI, M. E. Distribuição de renda e pobreza na agropecuária paranaense, 1970/80. Piracicaba: 1989, 129p. Dissertação (Mestrado) - Escola Superior de Agricultura "Luiz de Queiroz", Universidade de São Paulo.

DENISON, E. F.; Education, Economic Growth, and Gaps in Information. The Journal of Political Economy, v. 70, p. 124-128, Oct. 1962.

FUNDAÇÃo INSTITUTO BRASILEIRO DE GEOGRAFIA E ESTATÍSTICA. Censo Agropecuário do Paraná, 1970, 1980.

FUNDAÇÃO INSTITUTO BRASILEIRO DE GEOGRAFIA E ESTATÍSTICA. Censo Demográfico do Paraná, 1970, 1980, 1991.

FUNDAÇÃO INSTITUTO BRASILEIRO DE GEOGRAFIA E ESTATÍSTICA. Estatísticas Históricas do Brasil, 2. ed., Rio de Janeiro, 1993.

FUNDAÇÃO INSTITUTO BRASILEIRO DE GEOGRAFIA E ESTATÍSTICA. Inquéritos Especiais - Indústria da Construção, v. 6, n. 4, 1980. 
FURTADO, C. Dialética do desenvolvimento. Rio de Janeiro: Fundo de cultura, 1964 p. 122

GAZETA MERCANTIL - Balanço anual - Paraná, ago. 1995.

GIBBON, V. H. Taxas de retorno dos investimentos em educação no Brasil: uma análise desagregada. Revista Brasileira de Economia, v. 29, n. 3, p.109-133, jul./set. 1975.

GISSER, M. Schooling and the farm problem. Econometrica, v.33, n.3, p.582-592, Jul. 1965.

GOODWIN, B. K.; SCHROEDER T. C.; Human capital, producer education programs, and the adoption of forward pricing methods. American Journal Agricultural Economics, n. 76, p.936-947, Nov. 1994.

GRAZIANO DA SILVA, J. A nova dinâmica da agricultura brasileira. São Paulo: Unicamp, 1996. p.217.

GREENE, W. H. Econometric Analysis . Englewood Cliffs: Prentice-hall, 1993 p. 578615.

GRILICHES, Z. Hybrid corn: an exploration in the economics of technological change. Econometrica, v.25, n. 4, p.501-22, 0ct. 1957.

HAYAMI, Y,; RUTTAN, V. W. Agricultural productivity defferences among countries. American Economic Review, v. 60, n.5, p.895-911, Dec. 1970.

HOFFMANN, R. A dinâmica da modernização da agricultura em 157 microrregiões homogéneas do Brasil. Revista de Economia e Sociologia Rural, v. 30, n.4, p.271290, out./dez. 1992. 
HOFFMANN, R.; KAGEYAMA, A. A. Modernização da agricultura e distribuição de renda no Brasil, Pesquisa e Planejamento Econômico, v.15, n. 1, p.171-208, abr. 1985.

HUFFMAN, W. E. Allocative efficiency: the role of human capital. The Quarterly Journal of Economics, v. 91, n. 1, p. 59-79, Feb. 1977.

HUFFMAN, W. E. Farm and off-farm work decisions: the role of human capital. The Review of Economics and Statistics, v. 62 n. 1, Feb. 1980.

ILHA, A. S. da; LIMA, J. E. Impacto da educação na pequena produção agricola em Minas Gerais. Pesquisa e Planejamento Econômico, v. 19, n. 1 p.183-202, abr. 1989.

IPARDES Relatório de pesquisa. Curitiba: out. 1988

IPARDES Relatório de pesquisa. Curitiba: set. 1984.

JOHNSTON, B. F.; MELLOR, J. W. The Role of agriculture in economic development. American Economic Review, v. 51, p.566-593, Sep. 1961.

KASSOUF, A. L. Retornos à educação e treinamentos nos setores urbano e rural do Brasil. In: CONGRESSO BRASILEIRO DE ECONOMIA E SOCIOLOGIA RURAL, 34, Aracajú, 1996. Anais. Brasilia: SOBER, 1996. v.1, p.771-783.

KIYUNA, I. Modernização da agricultura e distribuição da renda no estado de São Paulo, 1980. In: CONGRESSO BRASILEIRO DE ECONOMIA E SOCIOLOGIA RURAL, 28, Florianópolis, 1990. Anais. Brasilia: SOBER, 1990.

KMENTA, J. Elementos de econometria. São Paulo: Atlas, 1994. v.2, p.600-639. 
KONZEN, O. G.; ZAPPAROLI, I. D. Estrutura agrária e capitalização da agricultura no Paraná. Revista de Economia e Sociologia Rural, v. 28, n.4, p.155-173, out./dez. 1990.

LANDIM, J. R. M.; MONTEIRO, M. A. A. O processo de modernização da agricultura e a estrutura produtiva da microrregião homogênea Serra de Jaboticabal, SP. Revista de economia e sociologia rural, v. 29, n. 3, p.229-248, jul./set. 1991.

LANGONI, C. G. As causas do crescimento econômico do Brasil. Rio de Janeiro: APEC, 1974. p.84-117.

LOCKEED, M. E; JANISON, D. T.; LAU, L. J. Farmer education and farm efficency: a survey. Economic Development and Cultural Change, v. 29, n. 1, p.37-76, Oct. 1980.

MAGAlhães FILHO, F. Evolução da economia paranaense. Revista Paranaense de Desenvolvimento, Curitiba: n. 87, p.131-148, jan./abr. 1996.

MALATHY, R. Education and women's time allocation to nonmarket work in na urban setting in India. Economic Development and Cultural Change, v. 42, n. 4, p.743757, Jul. 1994.

MINCER, J. Schooling, experience, and earnings. New York, National Bureau of Economic Research, 152p. 1974.

MORIMUNE, K. "t" test in a structural equacion. Econometrica, v. 57, n. 6, 1.3411.360p, Nov. 1989.

MYINT, H. Educação e desenvolvimento: Um balanço teórico. In: PEREIRA, L. Desenvolvimento, trabalho e educação. Rio de Janeiro: Zahar, 1967. p.130-147. 
NICHOLLS, W. H. O "excedente agrícola" como fator de desenvolvimento econômico. In: ARAÚJO P. F. C. de; SCHUH, G. E. (Coord.) Desenvolvimento da agricultura: Educação, Pesquisa e Assistência Técnica. São Paulo: Pioneira, 1975a. v. 2, p. $3-38$

PAIVA, R. M. Modernização e dualismo tecnológico na agricultura: uma reformulação. Pesquisa e Planejamento Econômico, v. 5, n. 1, p.117-161, 1975.

PEREIRA, L. B.; LUGNANI, A. C. Evolução da produção agrícola paranaense no período pós-modernização: análise das principais transformações e suas causas. In: CONGRESSO BRASILEIRO DE ECONOMIA E SOCIOLOGIA RURAL, Piracicaba, 1989. Anais. Brasilia: SOBER, 1989. p.391-415.

PNAD - Pesquisa Nacional por Amostras de Domicílio. Rio de Janeiro: IBGE, 1985, $1990,1995$.

RAM, R. Role of education in production: a slightly new approach. Quarterly Journal of Economics, v. 95, n. 2, Sep. 1980.

RELATÓRIO SOBRE O DESENVOLVIMENTO HUMANO NO BRASIL. Brasilia: IPEA, 1996.

RELATÓRIO SOBRE O DESENVOLVIMENTO MUNDIAL. Washinton: Banco Mundial, 1996.

RIBEIRO, J. L. A contribuição da educação na produção agrícola. Revista de Economia Rural, v. 17, n. 4, p. 86-118, set. 1979.

ROMEIRO, A R. Agricultura e distribuição de renda: o sentido atual da reforma agrária no Brasil. In: CONGRESSO BRASILEIRO DE ECONOMIA E SOCIOLOGIA RURAL, 28, Florianópolis, 1990. Anais. Brasilia: SOBER, 1990. 
ROMER, P. M. Endogenous technological change. Jornal of Political Economy, v. 98, n. 5, p.S71-S102, Oct. 1990.

SCHUH, G. E. A modernização da agricultura brasileira: uma interpretação, In: CONTADOR, C. R.; (Coord.), Tecnologia e desenvolvimento agrícola. Rio de Janeior: IPEA/INPES, 1975. p.7-45.

SCHUltZ, T. W. Investment in Human Capital. American Economic Review, v.51, Mar. 1961.

SCHULTZ, T. W. O Capital Humano - investimento em educação e pesquisa. Rio de Janeior: Zahar, 1973. p.1-100.

SCHULTZ, T. W. Uma política para redistribuir as perdas sociais do crescimento econòmico. In: CONTADOR, C. R.; (coord.) Tecnologia e desenvolvimento agrícola. Rio de Janeiro: IPEA/INPES, 1975a. 181-194 p.

SILBERBERG, E. The Structure of Economics: A mathematical Analysis. p.190-207, 1978.

SINDICATO DOS TRABALHADORES DA INDÚSTRIA DA CONSTRUÇÃO CIVIL - SINDUSCON; Relatório de Pesquisa, Curitiba: 1995.

THAME, A. C. M.; VICENTE, J. R; VICENTE, M. C. M. Escolaridade e Mão-deobra rural no Brasil, 1970-80. São Paulo: Secretaria de Agricultura e Abastecimento, Instituto de Economia Agrícola, 1987. 37p.

VERA, F.; ALVES, E. R. Urbanização: desafio à produtividade agrícola. Conjuntura Econômica, v.39, n. 3, mar/1985. p.159-167.

WELCH, F. Education in production. Journal of Political Economy, v. 78, n. 1, p.3539, Jan. 1970. 


\section{BIBLIOGRAFIA RECOMENDADA}

ALVES, E. L. G; SOARES, F. V. Ocupação e escolaridade: tendências recentes na grande São Paulo. Texto para discussão. IPEA, n. 428, p. 1-57, jun. 1996.

AMADEO, E.; CAMARGO, J. M.; GONZAGA, G.; BARROS, R.; MENDONÇA, R. A natureza e o funcionamento do mercado de trabalho brasileiro desde 1980., Texto para discussão. IPEA, n. 353, p. 1-33, out. 1994

ARAÚJO, P. F. C. de; NARDIN, M. S. Considerações sobre a escolaridade de produtores rurais e acesso as fontes de difusão de tecnologia no Brasil. Piracicaba: ESALQ, 49p. (Relatório de pesquisa), 1994.

BARROS, R. P. de; MENDONÇA, R. S. P. A distribuição de renda. GAZETA MERCANTIL, São Paulo, 24 fev. 1997. p.A7.

BONELLI, R.; RAMOS, L. Distribuição de renda no Brasil: avaliação das tendências de longo prazo e mudanças na desigualdade desde meados dos anos 70. Revista Brasileira de Economia, v. 49, n. 2, p.353-373, abr.jun. 1995.

DEVIEES OSORIO, J. E. Análise da produção e da produtividade do trabalho na agricultura de dezenove países latino-americanos. Piracicaba: 1996. 137p. Dissertação (Mestrado) - Escola Superior de Agricultura "Luiz de Queiroz", Universidade de São Paulo. 
ENGLER, J. J. C. O capital humano numa função de produção na agricultura de São Paulo. Pesquisa e Planejamento Econômico, v. 9, n. 3, p.845-884, dez. 1979.

GOETZ, S. J. Human Capital and Rural Labor Issues. American Journal Agricultural Economics, n. 75, p.1164-1168, Dec. 1993.

HOFFMANN, R: VIEIRA, S. Análise de regressão: uma introdução a econometria. São Paulo: Hucitec, 1977. 339p.

ILHA, A. S. da. Formação dos recursos humanos e desenvolvimento agrícola. In: TEIXEIRA, E. C.; Desenvolvimento agrícola na década de 90 e no século XXI. Viçosa: Editores, 1993 p.93-101

IPARDES Relatório de pesquisa. Curitiba: 1985.

IPARDES Relatório de pesquisa. Curitiba: nov. 1994.

KELEJIAN, H. H.; OATES, W. E. Introdução a econometria. Rio de Janeiro: Campus, 1978, p.247-254.

LAMBERT, J. Os dois Brasis. São Paulo: Brasiliana, 1971. p.101-126.

MARTINS, R. S.; MASSOLA, M. P. A dinâmica da agricultura paranaense nos anos 70 e 80: o caso das culturas de verão. Revista de Economia e Sociologia Rural, v. 32, n. 3, p.305-321, jul./set. 1994.

MELLOR, J. W. O planejamento do desenvolvimento agrícola. Rio de Janeiro: O cruzeiro, 1966. p. 15-130.

NICHOLLS, W. H. A economia agrícola brasileira: desempenho e política recente. In: CONTADOR, C. R; (Coord.) Tecnologia e desenvolvimento agrícola. Rio de Janeiro: IPEA/INPES, 1975b. p.47-88. 
PAIVA. R. M. Os baixos niveis de renda e de salários na agricultura brasileira. In: CONTADOR, C. R:: (Coord.) Tecnologia e desenvolvimento agrícola. Rio de Janeiro: IPEA/INPES, 1975. p.195-231.

PASTORE. A. C.; ALVES, E. R. A.: RIZZIERE, J. A. B. A inovação induzida e os limites da modernização na agricultura brasileira. Revista de Economia Rural, v. 14. n. 1, p.257-285, jan. 1976.

PATRICK. G. F.: KEHRBERG, E.W. Custos e retornos da educação em cinco áreas agricolas da região leste do Brasil. In: ARAÚJO P. F. C. de; SCHUH, G. E. (Coord.) Desenvolvimento da agricultura: Educacão, Pesquisa e Assistência Técnica. São Paulo: Pioneira, 1975, v. 2, p.17-34.

SANTOS. R. F. Análise crítica da interpretação neoclássica do processo de modernização da agricultura brasileira. Revista de Economia Política, v. 8, n. 3 , p. $131-148$, jul./set. 1988

SCHLLTZ, T. W. A transformação da agricultura tradicional. Rio de Janeiro: Zahar. 1965.207p.

SCHULTZ, T. W. The value of the ability to deal with disequilibria. Journal of Economic Literature, v. 13, n. 3, p. 827-846, Sep. 1975b.

VICENTE, J. R. Influência de educação, pesquisa e assistência técnica na produtividade da agricultura brasileira na década de 70. Piracicaba, 1989. 193p. Dissertação (Mestrado) - Escola Superior de Agricultura "Luiz de Queiroz", Universidade de São Paulo. 
APÈNDICE 
APÈNDICE I - Demonstração algébrica das condições de identificações de um sistema de equações simultâneas.

Duas condições são requeridas para checar se as equações são ou não identificadas ${ }^{60}$ : condição de ordem e a condição de Rank (posto). Para a condição de ordem (condição necessária) deve ser satisfeita a condição da seguinte inequação: $\mathrm{M}-\mathrm{I} \leq \mathrm{J}$ onde $\mathrm{M}$ é o número de variáveis endógenas do sistema de equações e $\mathrm{J}$ é o número de restrições de cada equação.

- Se $\mathrm{M}-1<\mathrm{J}$, a equação é super identificada;

- Se $M-1=\mathrm{J}$, a equação é exatamente identificada.

Rescrevendo as equações 1 e 2 do presente trabalho tem-se:

$$
\begin{aligned}
& S=a_{1}-a_{z} T-a_{3} C-a_{+} E-a_{3} A+u \\
& S=b_{I}-b_{2} T-b_{3} I-b_{4} E-v
\end{aligned}
$$

transformando as eq. 01 e 02 na forma implicita, tem-se:

$$
\begin{aligned}
& S-a_{1}-a_{2} T-a_{3} C-b_{3} I-a_{4} E-a_{5} A=u \\
& S-b_{1}-b_{2} T-a_{3} C-b_{3} \bar{S}-b_{4} E-a_{5} A=v
\end{aligned}
$$

Checando inicialmente a condição de ordem para a eq. 1.a tem-se que $\mathrm{M}=2(\mathrm{~W}$ e $L)$, e $J=1$ onde a restrição desta equação é a nulidade de $b_{乏}\left(b_{\S}=0\right)$. Substituindo os valores de $\mathrm{M}$ e $\mathrm{J}$ na inequação $(\mathrm{M}-1 \leq \mathrm{J}$ ) tem-se $2-1=1$, e com isso, conclui-se que a eq. l.a é exatamente identificada.

\footnotetext{
${ }^{\circ 0}$ Baseado em Greene (1993), a partir da pag. 589.
} 
Raciocínio análogo para a eq. 2 a onde a restrição é $a_{3}=0$. Assim, substituindo os valores de $\mathrm{M}$ e $\mathrm{J}$ na inequação $(\mathrm{M}-1 \leq \mathrm{J})$ tem-se $2-1=1$, e também conclui-se que a eq. 2.a é exatamente identificada.

Para as condições de rank (necessárias e suficientes) tem-se que: Rank $=\mathrm{M}-1$. Entretanto, ressalta-se que o Rank é um produto de matrizes das restrições (R) e dos coeficientes das variáveis endógenas e exógenas $\left[\begin{array}{l}\Gamma \\ B\end{array}\right]$. A matriz das restrições consistese em: $R=J \times(M+K)$, onde $R$ é uma matriz de restrições de cada equação (a restrição assume valor igual a 1 ), com dimensões $J \times(M+K)$ onde $J$ continua sendo o número de restrições de cada equação, $M$ é o número de variáveis endógenas do sistema de equações e $\mathrm{K}$ é o número de variáveis exógenas de cada equação. Já a matriz $\left[\begin{array}{l}\Gamma \\ \mathrm{B}\end{array}\right]$ compreende os coeficientes das variáveis endógenas e exógenas do sistema de equações. Dessa forma, o Rank $=[R] *\left[\begin{array}{l}\Gamma \\ B\end{array}\right]$.

Calculando as dimensões da matriz $\mathrm{R}$ temos $\mathrm{R}=\mathrm{J} \times(\mathrm{M}+\mathrm{K}), \Rightarrow \mathrm{R}=1 \times(2+4)$, portanto, $\mathrm{R}=1 \times 6$

Calculando o Rank da eq. (01.a) tem-se $[R]=\left[\begin{array}{llllll}0 & 0 & 0 & 1 & 0 & 0\end{array}\right]_{1 \times 6} \quad$ e $\left[\begin{array}{l}\Gamma \\ B\end{array}\right]=\left[\begin{array}{cc}1 & 1 \\ -a_{2} & -b_{2} \\ -a_{3} & 0 \\ 0 & -b_{3} \\ -a_{4} & -b_{4} \\ -a_{5} & 0\end{array}\right]_{6 \times 2}$, fazendo o produto tem-se o resultado a seguir: 
$\left[\begin{array}{llllll}0 & 0 & 0 & 1 & 0 & 0\end{array}\right]_{1 \times 0} *\left[\begin{array}{cc}1 & 1 \\ -a_{2} & -b_{2} \\ -a_{3} & 0 \\ 0 & -b_{3} \\ -a_{+} & -b_{+} \\ -a_{5} & 0\end{array}\right]_{0 \times 2}=\left[\begin{array}{ll}0 & -b_{3}\end{array}\right]_{1 \times 2}$ para condição necessário e suficiente tem-se que $\operatorname{Rank}=M-1$. Como $\operatorname{Rank}=1^{61}$, e $M=2$ e, substituindo esses valores temos que $1=2-1$. Logo conclui-se que a primeira equação é exatamente identificada.

Para a segunda equação, tem-se sintetizado o seguinte resultado:

$\left[\begin{array}{llllll}0 & 0 & 1 & 0 & 0 & 0 \\ 0 & 0 & 0 & 0 & 0 & 1\end{array}\right]_{2 \times 6} *\left[\begin{array}{cc}1 & 1 \\ -a_{2} & -b_{2} \\ -a_{3} & 0 \\ 0 & -b_{3} \\ -a_{+} & -b_{4} \\ -a_{5} & 0\end{array}\right]_{6 \times 2}=\left[\begin{array}{ll}-a_{3} & 0 \\ -a_{5} & 0\end{array}\right]_{2 \times 2}$, da mesma forma que $a$. anterior, a equação é exatamente identificada, pois $\operatorname{Rank}=1$ e $\mathrm{M}=2$, e assim a condição do $\operatorname{Rank}=$ M - 1 e satisfeita.

ol O Rank é o numero de colunas nào nulas do produto de matrizes. 
APÊNDICE II - Resultados das estimativas econométricas das equações de oferta e de demanda para os anos de 1970, 1980 e para o conjunto 1970-1980, fornecidos pelo programa Statistica.

Resultados para a equação de demanda - 1970

Regression Summary for Dependent Variable: $S$ -

$\mathrm{R}=.63775520 \mathrm{R}^{2}=.40673169$. Adjusted $\mathrm{R}^{\mathrm{z}}=.28183310$

$F(4,19)=3.2565 p<03411$ Std.Error of estimate: .45239

\begin{tabular}{cllllll}
\hline & \multicolumn{2}{c}{$\begin{array}{l}\text { St. Err. } \\
\text { of BETA }\end{array}$} & B & $\begin{array}{c}\text { St. Err. } \\
\text { of B }\end{array}$ & t(19) & p-level \\
\hline Interept & & & 5.94401 & 4.20115 & 1.41485 & 0.17329 \\
$T$ & -0.45924 & 0.31375 & -0.68453 & 0.46767 & -1.46372 & 0.15962 \\
C & 1.57735 & 0.59167 & 1.29235 & 0.48476 & 2.66594 & 0.01527 \\
E & -0.42439 & 0.40045 & -0.63643 & 0.60053 & -1.05978 & 0.30253 \\
$A$ & 1.16830 & 0.42378 & 0.74093 & 0.26876 & 2.75683 & 0.01255 \\
\hline
\end{tabular}

Fonte: Dados da pesquisa.

Covariances of Regression Coefficients B: DV: (pe1 70.sta)

\begin{tabular}{lcccc}
\hline & EST & C & E & A \\
\hline EST & 0.21871 & $-0,16945$ & 0,22805 & $-0,07289$ \\
C & $-0,16945$ & 0,23499 & -0.24942 & 0.11680 \\
E & 0,22805 & -0.24942 & 0,36063 & $-0,11376$ \\
AH & $-0,07289$ & 0.11680 & $-0,11376$ & 0.07223 \\
\hline
\end{tabular}

Fonte: Dados da pesquisa.

Resultados para a equação de oferta - 1970

Regression Summary for Dependent Variable: $S$

$\mathrm{R}=.62035289 \mathrm{R}^{2}=.38483770$ Adjusted $\mathrm{R}^{2}=.29256336$

$F(3.20)=4.1706 p<.01903$ Std.Error of estimate: .44900

\begin{tabular}{lllllll}
\hline & BETA & $\begin{array}{l}\text { St. Err. } \\
\text { of BETA }\end{array}$ & B & $\begin{array}{l}\text { St. Err. } \\
\text { of B }\end{array}$ & t(20) & p-level \\
\hline Intercpt & & & -8.60445 & 4.82898 & $-1,78184$ & 0.08997 \\
T & 0,80613 & 0,32481 & 1,20160 & 0.48416 & 2.48184 & 0.02207 \\
I & -0.80045 & 0.29833 & $-0,62654$ & 0.23351 & -2.68311 & 0.01430 \\
E & 0,95411 & 0,27401 & 1,43079 & 0,41091 & 3,48205 & 0,00235 \\
\hline
\end{tabular}

Fonte: Dados da pesquisa.

Covariances of Regression Coefficients B: DV: (pel 70.sta)

\begin{tabular}{lccc}
\hline & T & I & E \\
\hline T & 0.23441 & $-0,08991$ & 0.14944 \\
I & $-0,08991$ & 0,05453 & -0.06671 \\
E & 0.14944 & -0.06671 & 0.16884 \\
\hline
\end{tabular}

Fonte: Dados da pesquisa. 
Resultados para a equação de demanda - 1980

Regression Summary for Dependent Variable: $S$

$\mathrm{R}=.81810822 \mathrm{R}^{2}=.66930106$ Adjusted $\mathrm{R}^{2}=.59968023$

$F(4.19)=9,6135 p<, 00020$ Std.Error of extimate: .26371

\begin{tabular}{lcccccc}
\hline & & St. Err. & \multicolumn{2}{c}{ St. Err. } \\
of BETA & B & of B & t(19) & p-level \\
\hline Intercpt & & & 6,62838 & 4,65427 & 1,42415 & 0.17062 \\
T & -0.67462 & 0.46444 & $-0,86911$ & 0.59834 & $-1,45254$ & 0,16267 \\
C & 1,86360 & 0.49294 & 1,12916 & 0.29867 & 3.78059 & 0.00126 \\
E & 0,12844 & 0.22510 & 0,19681 & 0,34490 & 0.57062 & 0.57495 \\
A & 1.67539 & 0.74159 & 0.95805 & 0.42406 & 2.25919 & 0.03582 \\
\hline
\end{tabular}

Fonte: Dados da pesquisa.

Covariances of Regression Coefficients B: DV: (pc180.sta)

\begin{tabular}{lcccc}
\hline & $\mathrm{T}$ & $\mathrm{C}$ & $\mathrm{E}$ & $\mathrm{A}$ \\
\hline $\mathrm{T}$ & 0.35801 & $-0,12558$ & $-0,12256$ & -0.23078 \\
$\mathrm{C}$ & $-0,12558$ & 0,08921 & 0,00370 & 0,11462 \\
$\mathrm{E}$ & $-0,12256$ & 0,00370 & 0,11896 & 0,05313 \\
$\mathrm{~A}$ & $-0,23078$ & 0,11462 & 0,05313 & 0.17983 \\
\hline
\end{tabular}

Fonte: Dados da pesquisa.

Resultados para a equação de oferta 1980

Regression Summary for Dependent Variable: S

$\mathrm{R}=.54424017 \mathrm{R}^{2}=, 29619736$ Adjusted $\mathrm{R}^{2=} .19062697$

$F(3,20)=2.8057 p<.06602$ Std.Error of extimate: 37498

\begin{tabular}{lcccccc}
\hline & & \multicolumn{2}{c}{ St. Err } \\
of BETA & BETA & & Bt. Err. & of B & t(20) & p-level \\
\hline Intercpt & & & 5,79828 & 2.85317 & 2,03222 & 0,05563 \\
$\mathrm{~T}$ & $-0,23686$ & 0,20708 & $-0,30515$ & 0,26678 & $-1,14380$ & 0,26621 \\
$\mathrm{I}$ & 0,07909 & 0,20105 & 0,05034 & 0,12797 & 0,39337 & 0,69821 \\
$\mathrm{E}$ & 0,54666 & 0,21408 & 0,83762 & 0,32802 & 2,55357 & 0,01893 \\
\hline
\end{tabular}

Fonte: Dados da pesquisa.

Covariances of Regression Coefficients B; DV: (pel 80.sta)

\begin{tabular}{lccc}
\hline & $T$ & $I$ & $E$ \\
\hline$T$ & 0,07117 & 0,00816 & $-0,03592$ \\
$I$ & 0,00816 & 0,01638 & $-0,01441$ \\
$E$ & $-0,03592$ & $-0,01441$ & 0.10760 \\
\hline
\end{tabular}

Fonte: Dados da pesquisa. 
Resultados para a equação de demanda no conjunto $1970-1980$

Regrexicn Summary for Dependent Tariable: $S$

$\mathrm{R}=.09562396 \mathrm{R}^{2}=.+8389269$. Adiusted $\mathrm{R}^{2}=.+2245134$

$F(5.42)=-875-p$ p .00003 Std.Error of ext imate: $.37+34$

\begin{tabular}{|c|c|c|c|c|c|c|}
\hline & BETA & $\begin{array}{c}\text { St. Err. } \\
\text { of BETA }\end{array}$ & $B$ & $\begin{array}{l}\text { St. EnT. } \\
\text { of } B\end{array}$ & $t(+2)$ & p-level \\
\hline interon & & & $3 .+2955$ & +.72314 & 0.72612 & 0.47179 \\
\hline$T$ & $-0.1+658$ & 0.20040 & -0.38960 & 0.53264 & -0.73144 & 0.46857 \\
\hline$c$ & 1.72612 & 0.53642 & 1.01373 & 0.31503 & 3.21786 & 0.00249 \\
\hline$E$ & $0.1+612$ & 0.25210 & -0.19327 & 0.33346 & -0.57960 & 0.56528 \\
\hline 1 & 1.05983 & $0 .+1858$ & 0.64302 & 0.25396 & 2.53199 & 0.01517 \\
\hline DEMM & -0.39321 & 0.16346 & -0.38332 & 0.15935 & -2.40550 & 0.02063 \\
\hline
\end{tabular}

Finte: Dader da pequansa

Covanances of Regression Coetficients B: DY: (pel70180.sta)

\begin{tabular}{|c|c|c|c|c|c|}
\hline & $T$ & $\mathrm{C}$ & $\mathrm{E}$ & $A$ & DEMNY \\
\hline $\bar{T}$ & 0.28371 & -0.13260 & 0.12822 & -0.11113 & 0.02417 \\
\hline $\mathrm{C}$ & 0.13260 & 0.09924 & -0.08852 & 0.07628 & -0.02680 \\
\hline$E$ & 0.12822 & -0.08852 & 0.11120 & -0.06669 & 0.01135 \\
\hline$A$ & .0 .11113 & 0.07628 & -0.06669 & 0.06450 & 40.01817 \\
\hline DLMAN & $0.02+17$ & -0.02680 & 0.01135 & -0.01817 & 0.02539 \\
\hline
\end{tabular}

Fone: Dados da pesquisa.

Resultados para a equação de oterta no conjunto 1970 - 1980

Regresica Summan for Dependant Variable: $H^{-}$

$\mathrm{R}=.01777886 \mathrm{R}=.38165072$. Adjused $\mathrm{R}^{2}=.32+12986$

$F(+.+3)=6.6350 p .00030$ Std. Error of estimate: .40495

\begin{tabular}{|c|c|c|c|c|c|c|}
\hline & BETA & $\begin{array}{l}\text { St. Err. } \\
\text { of BETA }\end{array}$ & $B$ & $\begin{array}{l}\text { St. Err. } \\
\text { of } B\end{array}$ & $t(43)$ & p-level \\
\hline Interupt & & & -9.54570 & 4.08961 & -2.33414 & 0.02433 \\
\hline $\mathrm{T}$ & 0.45610 & 0.14846 & 1.21225 & 0.39459 & 3.07219 & 0.00368 \\
\hline I & -0.32725 & 0.15535 & -0.23400 & 0.11108 & -2.10651 & 0.04103 \\
\hline$E$ & 0.70256 & 0.16086 & 0.92930 & 0.21277 & 4.36752 & 0.00008 \\
\hline DCMAN & $-0.0551+$ & 0.14533 & $-0.0 \$ 375$ & 0.14168 & -0.37937 & 0.70628 \\
\hline
\end{tabular}

Fonte: Dados da pesquisa.

Covariances of Regrexsion Coefficiants B: DV: (pel70180.sa)

\begin{tabular}{lcccc}
\hline & $\mathrm{T}$ & $\mathrm{I}$ & $\mathrm{E}$ & DCMNY \\
\hline $\mathrm{T}$ & 0.15570 & -0.02433 & 0.03359 & -0.00920 \\
$\mathrm{I}$ & -0.02433 & 0.01234 & -0.00987 & 0.00002 \\
$\mathrm{E}$ & 0.03359 & -0.00987 & 0.04527 & -0.01536 \\
DiMn & -0.00920 & 0.00002 & -0.01536 & 0.02007 \\
\hline
\end{tabular}

Fonte: Dados da pesquisia. 


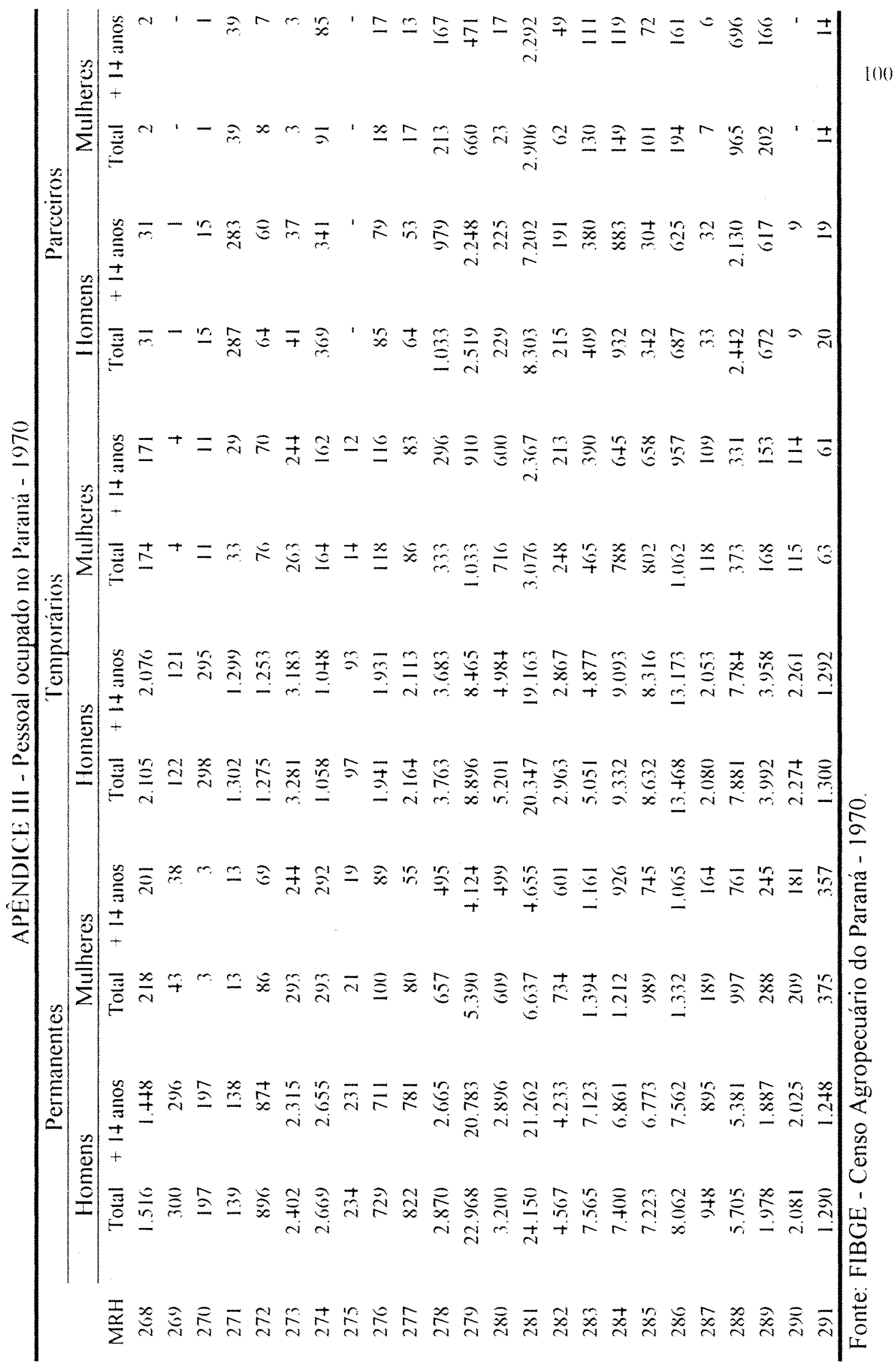




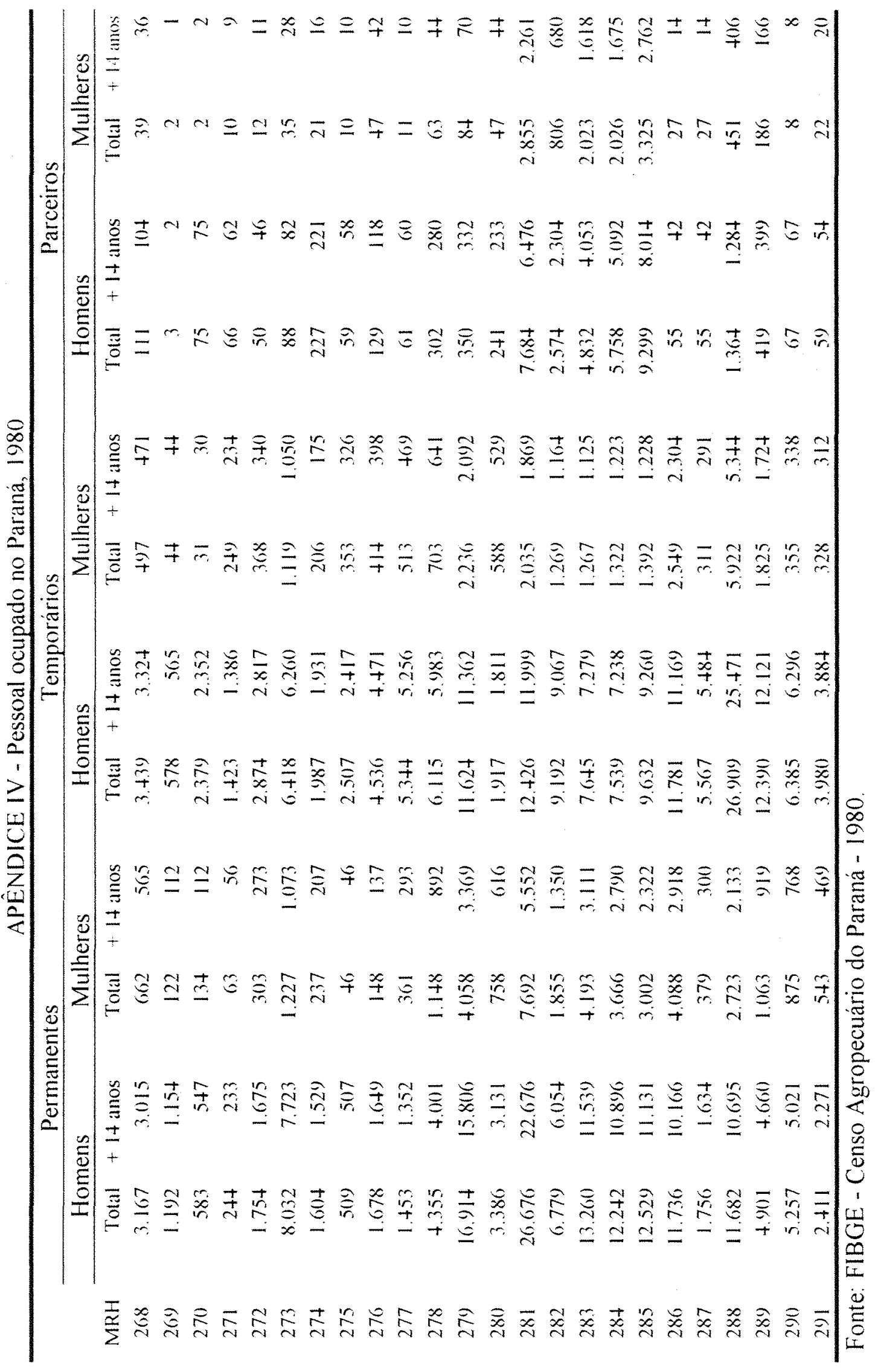




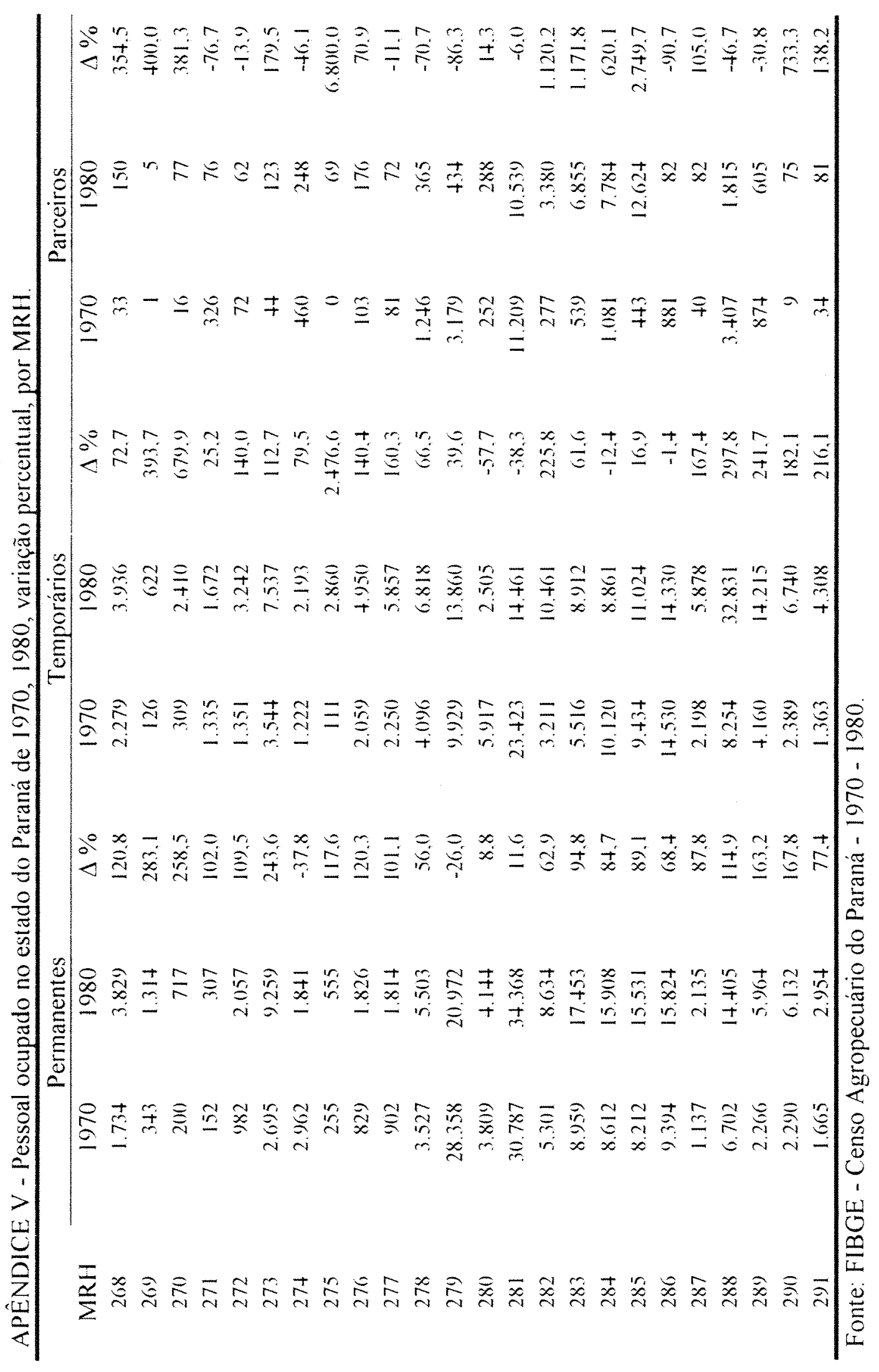




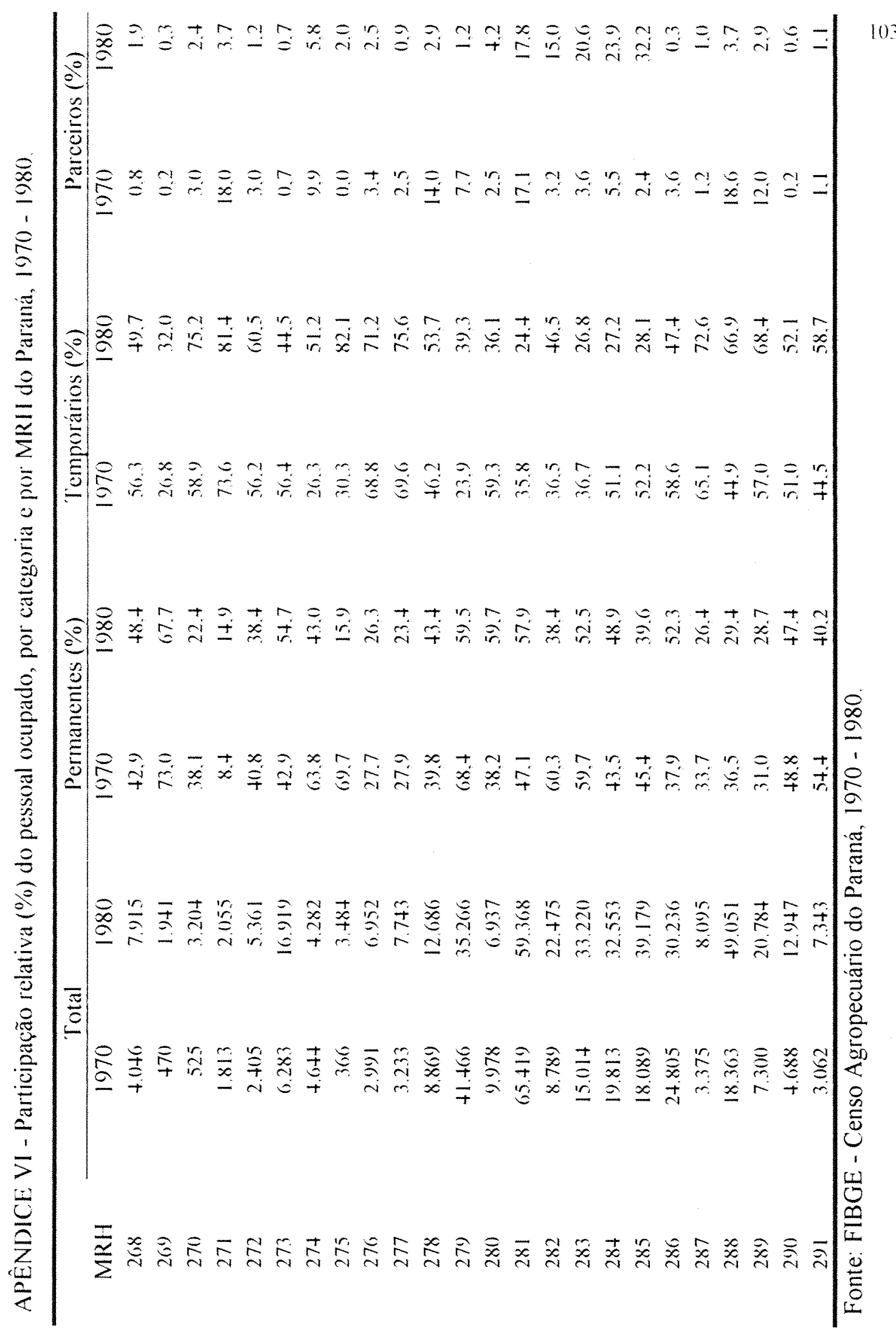


Apêndice VII - Área, Pessoal ocupado, suas variações e relação área-homem de 1970 - 1980 Area Pessoal ocupado

Área-homem

\begin{tabular}{|c|c|c|c|c|c|c|c|c|c|}
\hline MRH & 1970 & 1980 & Variaçào & 1970 & 1980 & Variação & 1970 & 1980 & Variaçăo \\
\hline 268 & 102.755 & 83.775 & -18.5 & 4.046 & 7.915 & 95,6 & 25.39 & 10,58 & -58.32 \\
\hline 269 & 4.583 & 4.969 & 8,4 & 470 & 1.941 & 313,0 & 9,75 & 2,56 & -73.75 \\
\hline 270 & 25,043 & 22.812 & $-8,9$ & 525 & 3.204 & 510,3 & 47,70 & 7,11 & $-85,07$ \\
\hline 271 & 30.311 & 26.663 & $-12,0$ & 1.813 & 2.055 & 13,3 & 16.71 & 12.97 & -22.39 \\
\hline 272 & 55.776 & 77.697 & 39.3 & 2.405 & 5.361 & 122.9 & 23.19 & 14,49 & -37.51 \\
\hline 273 & 86.200 & 195.866 & 127.2 & 6.283 & 16.919 & 169,3 & 13.71 & 11.57 & -15.62 \\
\hline 274 & 36.576 & 70.789 & 93.5 & 4.644 & 4.282 & $-7,8$ & 7,87 & 16.53 & 109.90 \\
\hline 275 & 35.981 & 49.276 & $\mathbf{3 7 , 0}$ & 366 & 3.484 & 851,9 & 98.30 & 14.14 & -85.61 \\
\hline 276 & 149.130 & 191.609 & 28.5 & 2.991 & 6.952 & 132,4 & 49,85 & 27.56 & -44.72 \\
\hline 277 & 125.153 & 166.651 & 33,2 & 3.233 & 7.743 & 139,5 & 38,71 & 21,52 & -44.40 \\
\hline 278 & 158.707 & 171.610 & 8,1 & 8.869 & 12.686 & 43,0 & 17,89 & 13.52 & $-24,40$ \\
\hline 279 & 300.993 & 334.345 & 11,1 & 41.466 & 35.266 & $-15,0$ & 7,25 & 9.48 & 30.61 \\
\hline 280 & 70.567 & 116.440 & 65.0 & 9.978 & 6.937 & $-30,5$ & 7,07 & 16.78 & 137.34 \\
\hline 281 & 213.893 & 360.007 & 68,3 & 65.419 & 59.368 & $-9,2$ & 3,26 & 6,06 & 85,47 \\
\hline 282 & 148.516 & 251.755 & 69.5 & 8.789 & 22,475 & 155,7 & 16,89 & 11,20 & -33.71 \\
\hline 283 & 83.851 & 64.735 & $-22,8$ & 15.014 & 33.220 & 121,3 & 5,58 & 1.94 & -65.11 \\
\hline 284 & 405.069 & 366.536 & $-9,5$ & 19.813 & 32.553 & 64,3 & 20.44 & 11.25 & -44.93 \\
\hline 285 & 290.868 & 212.805 & $-26,8$ & 18.089 & 39.179 & 116,6 & 16,07 & 5,43 & -66.22 \\
\hline 286 & 403.155 & 698.003 & 73,1 & 24.805 & 30.236 & 21,9 & 16,25 & 23.08 & 42.04 \\
\hline 287 & 131.103 & 198.739 & 51,6 & 3.375 & 8.095 & 139,9 & 38,84 & 24,55 & -36.80 \\
\hline 288 & 785.440 & 1.649 .572 & 110,0 & 18.363 & 49.051 & 167,1 & 42,77 & 33,62 & -21.38 \\
\hline 289 & 491.626 & 734.213 & 49,3 & 7.300 & 20.784 & 184,7 & 67,34 & 35,32 & .47 .55 \\
\hline 290 & 178.456 & 326.341 & 82,9 & 4.688 & 12.947 & 176,2 & 38,06 & 25,20 & $-33,78$ \\
\hline 291 & 75.357 & 120.323 & 59,7 & 3.062 & 7.343 & 139,8 & 24,61 & 16,38 & -33.42 \\
\hline
\end{tabular}

Fonte: FIBGE - Censos Agropecuário do Paraná 1970-1980. 
APĖNDICE VIII - Rendimentos (em mil cruzeiros nominais) dos trabalhadores rurais. assalariados e parceiros. do Paraná - 1970-1980.

\begin{tabular}{|c|c|c|c|c|c|c|}
\hline \multirow{3}{*}{$\begin{array}{c}\text { MRH } \\
268\end{array}$} & \multicolumn{3}{|c|}{1970} & \multicolumn{3}{|c|}{1980} \\
\hline & Salários & Quota-parte & Total & Salários & Quota-parte & Total \\
\hline & +889.00 & +2.00 & +931.00 & $309.6+5.00$ & 14.608 .00 & $32+253.00$ \\
\hline 269 & 2.239 .00 & 16.00 & 2.255 .00 & 185.293 .00 & 77.00 & 185.370 .00 \\
\hline 270 & 648.00 & 38.00 & 686.00 & 61.811 .00 & $2 .+27.00$ & $6+.238 .00$ \\
\hline 271 & +94.00 & 205.00 & 699.00 & 38.170 .00 & 1.136 .00 & 39.306 .00 \\
\hline 272 & 2.667 .00 & 95.00 & 2.762 .00 & 175.194 .00 & 12.473 .00 & 187.667 .00 \\
\hline 273 & 10.017 .00 & +7.00 & 10.064 .00 & $562.9+2.00$ & 8.239 .00 & 571.181 .00 \\
\hline 274 & 2.519 .00 & +11.00 & 2.930 .000 & $163 .+42.00$ & +.299 .00 & $167.7+1.00$ \\
\hline 275 & 1.549 .00 & 3.00 & 1.552 .00 & 53.182 .00 & 1.713 .00 & $5+.895 .00$ \\
\hline 276 & 2.691 .00 & 102.00 & 2.793 .00 & 156.073 .00 & 8.198 .00 & 164.271 .00 \\
\hline 277 & 2.409 .00 & 32.00 & $2.4+1.00$ & 140.365 .00 & 14.784 .00 & 155.149 .00 \\
\hline 278 & 6.116 .00 & 985.00 & 7.101 .00 & $350 .+94.00$ & 14.189 .00 & $36+.683 .00$ \\
\hline 279 & +7.677 .00 & 3.258 .00 & 50.935 .00 & 1.345 .010 .00 & 22.371 .00 & 1.367 .381 .00 \\
\hline 280 & 8.537 .00 & +93.00 & 9.030 .00 & 351.849 .00 & 20.431 .00 & 372.280 .00 \\
\hline 281 & $57.81+.00$ & 7.482 .00 & 65.296 .00 & 2.033 .012 .00 & 365.753 .00 & 2.398 .765 .00 \\
\hline 282 & 11.869 .00 & +80.00 & 12.349 .00 & 551.499 .00 & $161.6+0.00$ & 713.139 .00 \\
\hline 283 & 22.867 .00 & +50.00 & 23.317 .00 & 1.329 .205 .00 & 270.037 .00 & $1.599 .2+2.00$ \\
\hline 284 & 16.231 .00 & 575.00 & 16.806 .00 & 893.215 .00 & 312.753 .00 & 1.205 .968 .00 \\
\hline 285 & 23.507 .00 & +26.00 & 23.933 .00 & 1.222 .661 .00 & +09.506 .00 & 1.632 .167 .00 \\
\hline 286 & 22.010 .00 & 767.00 & 22.777 .00 & $1.29+.953 .00$ & 156.158 .00 & 1.451 .111 .00 \\
\hline 287 & 2.553 .00 & 26.00 & 2.579 .00 & 165.874 .00 & 2.566 .00 & 168.440 .00 \\
\hline 288 & 16.925 .00 & 3.007 .00 & 19.932 .00 & 1.302 .436 .00 & $11+.02+.00$ & $1 .+16 .+60.00$ \\
\hline 289 & 4.707 .00 & 465.00 & 5.172 .00 & 481.271 .00 & 34.789 .00 & 516.060 .00 \\
\hline 290 & 5.182 .00 & +4.00 & 5.226 .00 & $+93 .+97.00$ & 2.057 .00 & +95.554 .00 \\
\hline 291 & 3.778 .00 & 38.00 & 3.816 .00 & 202.931 .00 & 6.972 .00 & 209.903 .00 \\
\hline
\end{tabular}

Fonte: FIBGE - Censo Agropecuário do Paraná - 1970-1980. 


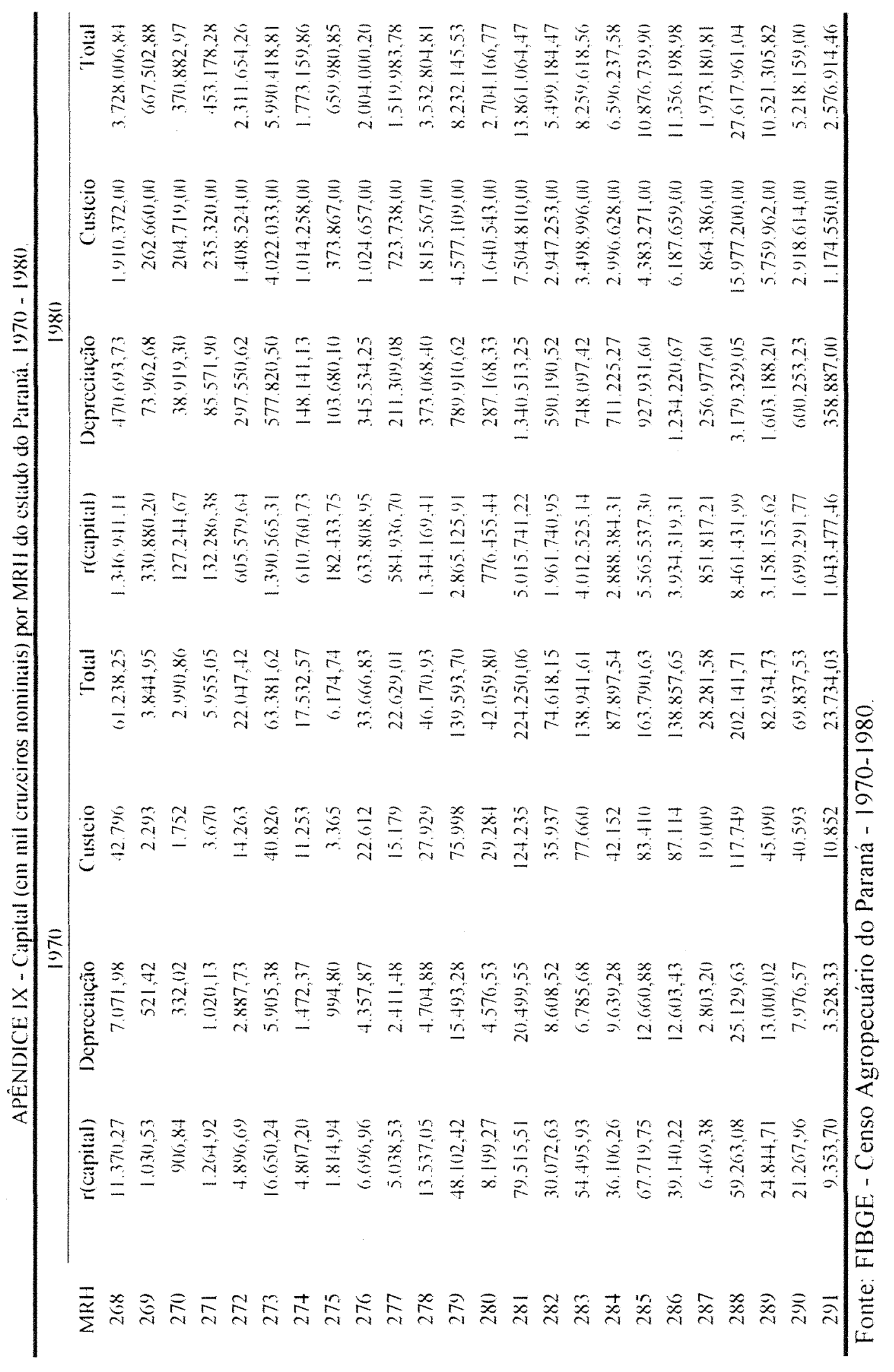

106 


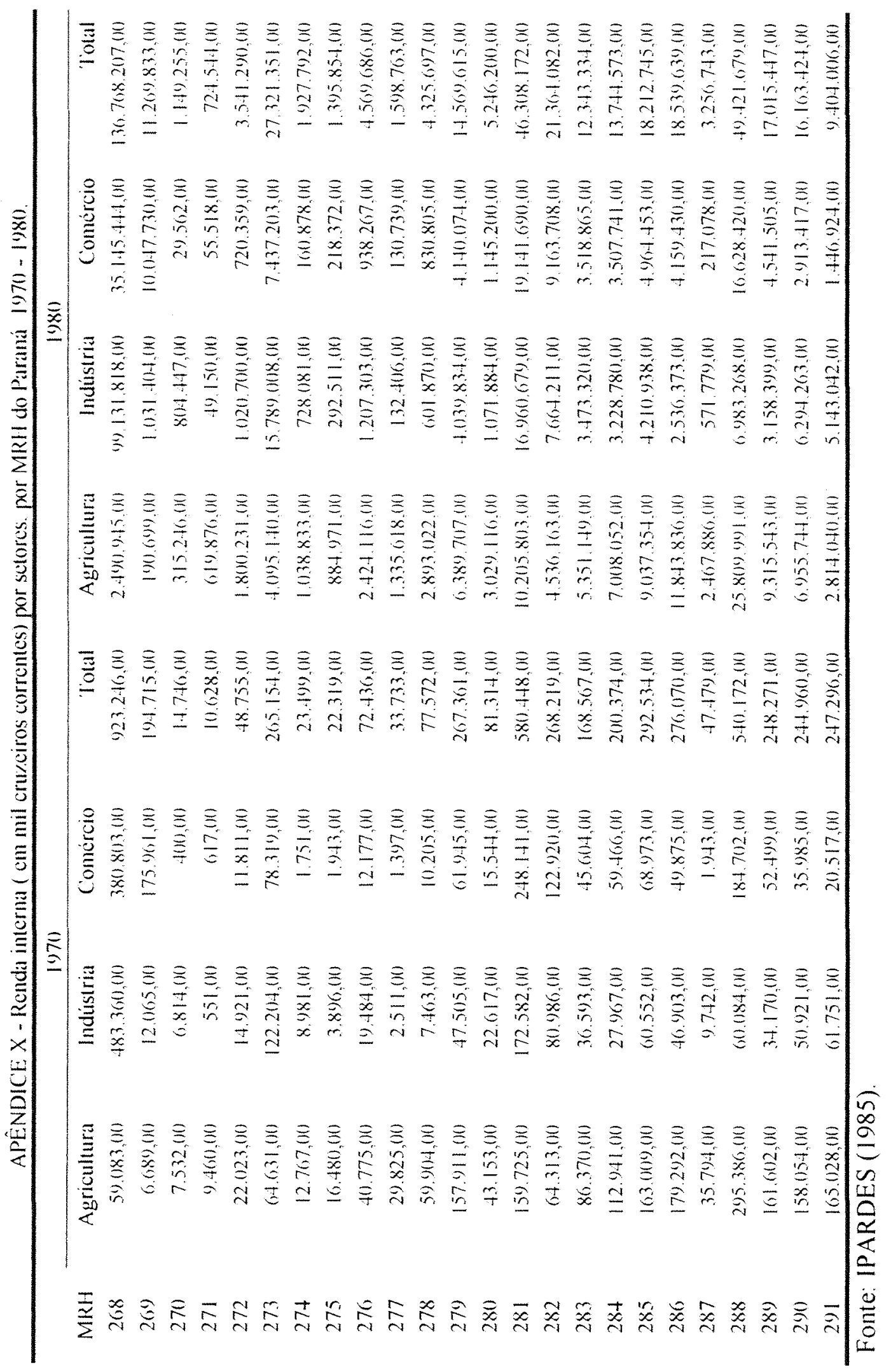

107 